
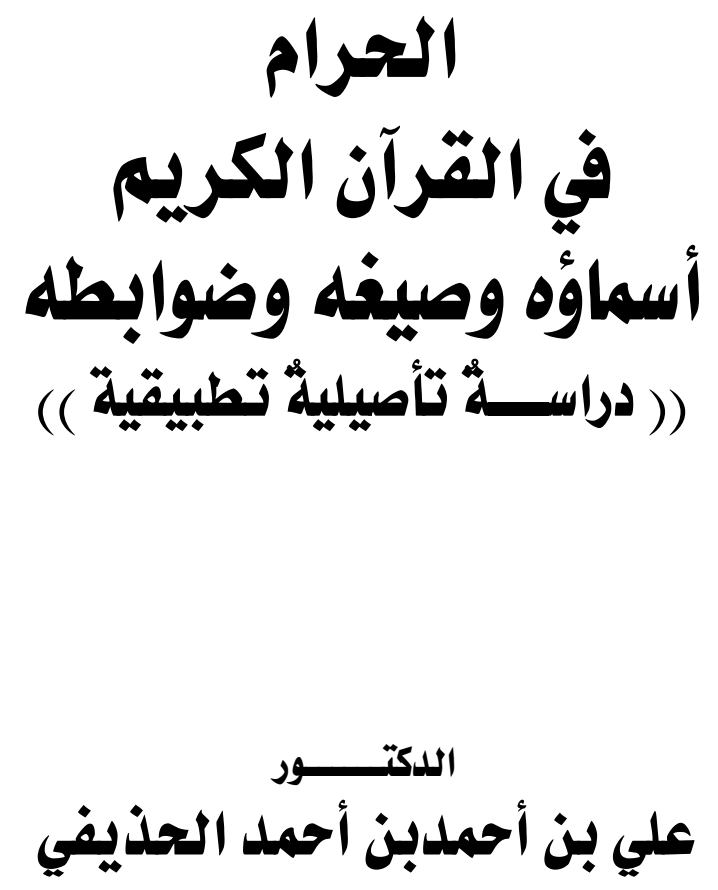

الأستاخ المشارهـ بكلية الضراسات القهنا ئية والأنظمة بجاهمهة أم القرى 


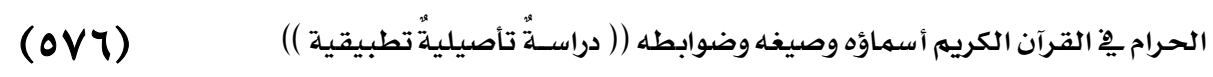




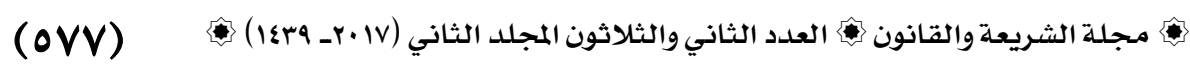

المقدمة.

الحمد لله وحده، والصلاة والسلام على من لا ببي بعده... وبعد:

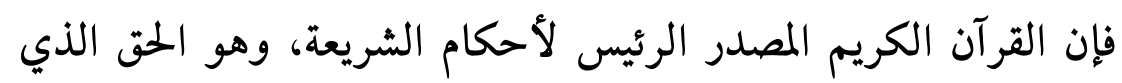

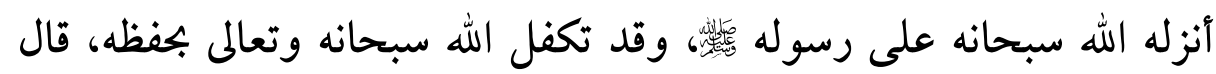

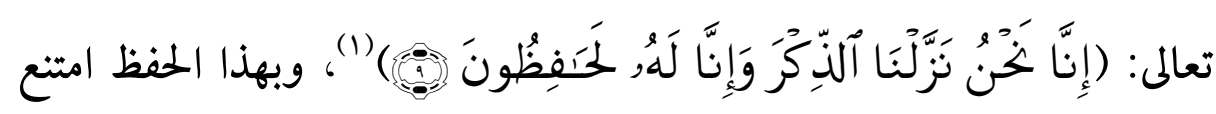
على كل أحد التبديل والتحريف في هذا القرآن

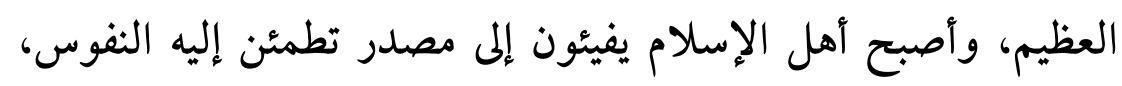

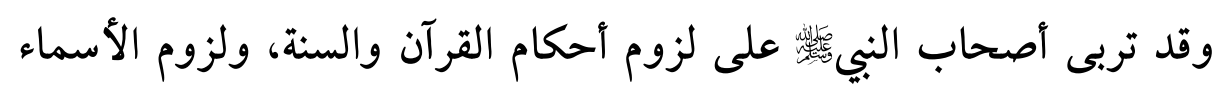

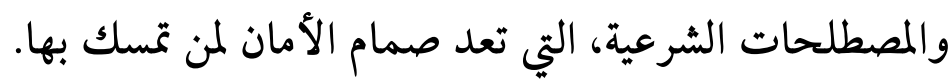

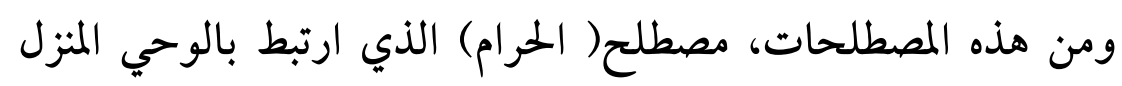

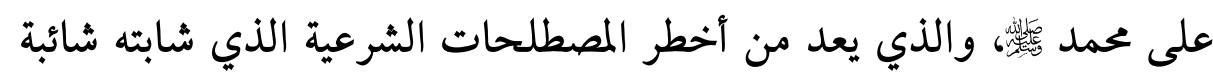

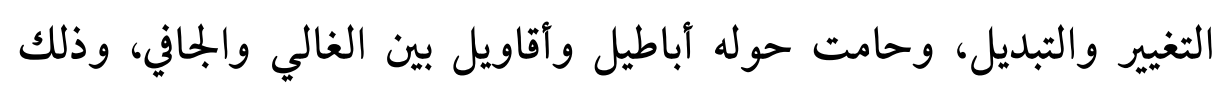

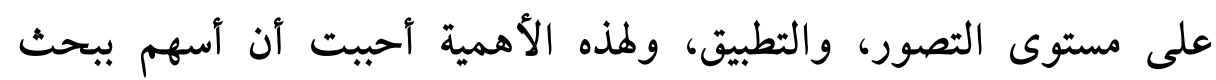
عنو انه: على

(الحرام في القر آن الكريع... أسماؤه وصيغه وضوابطه " دراسةّ تأصيليةّ تطبيقية)،

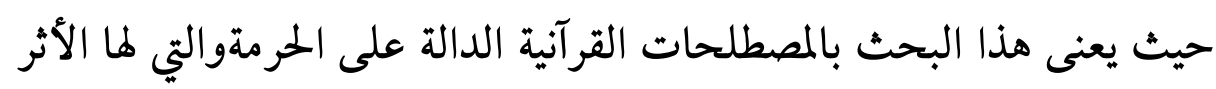

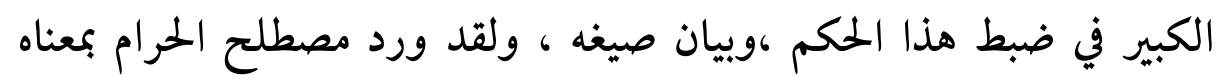
الشرعي في القرآن الكريم ثمان وسبعين مرة وهذا يدل على أهميته. 


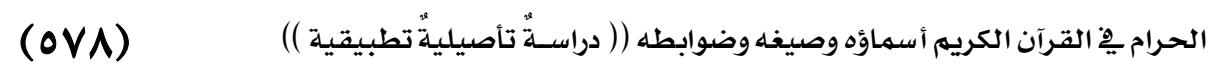

وقد اخترت مصطلح الحرام لضبط حقيقته، وبيان مسمياته وصيغه من

خلال الكتاب العزيز، وذلك لخطورة التحريم والقول على الله بلا علم، قال

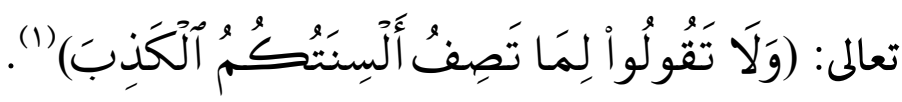

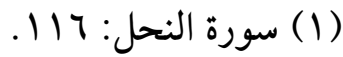


أهمية الموضوع:

1 - خطورة التحريم والقول على الله تعالى بغير علم.

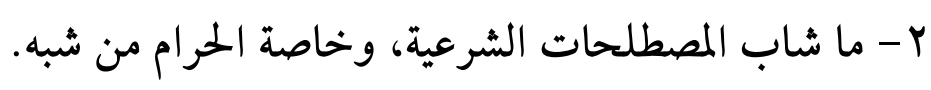

\section{أهداف الموضوع:}

( ) الوقوف على صيخ الحرام وضبطها من خلال القرآن الكريم .

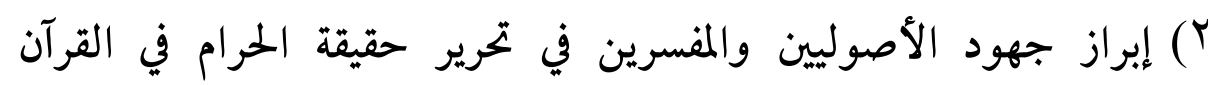
الكريم.

r) تدريب الدارس الأصولي على التطبيق على صيغ الحرام من خلال آيات

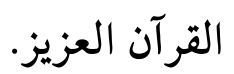
؟) العناية بالمصطلحات الشرعية . لقرئر.

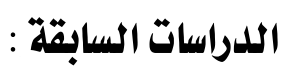

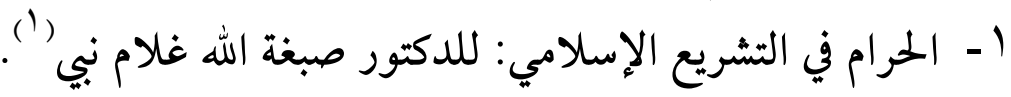

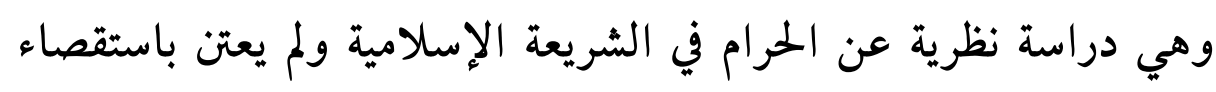

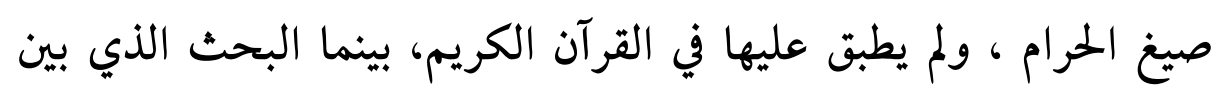

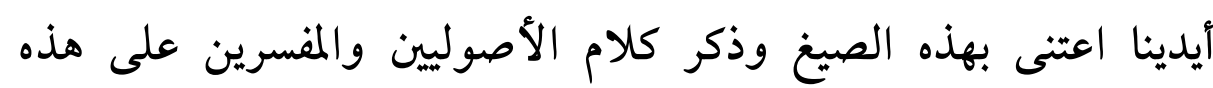

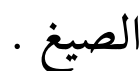
r- الحرام لغيره دراسة نظرية تطبيقية: للدكتور علي باروم (r).

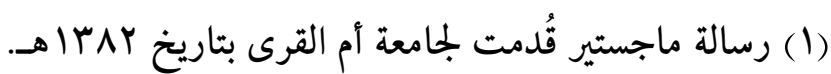

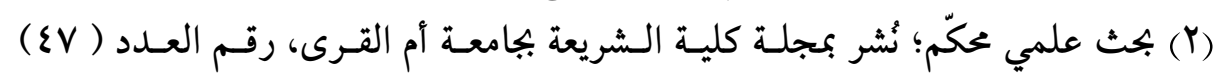
رجب • بـأهـ 


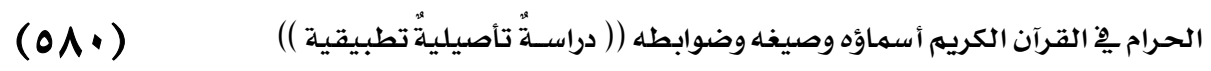

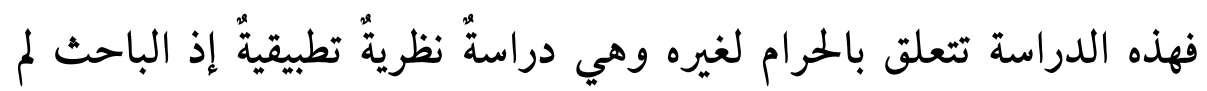

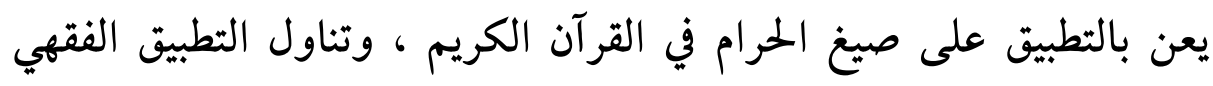
على مسائل الحرام لغيره وتعتبر الدراسة خارجة عن موضوع البحث الذي أتناوله.

r- صيغ التحريم عند الأصوليين مع التطبيق على ما ورد منها في سورة المائدة:

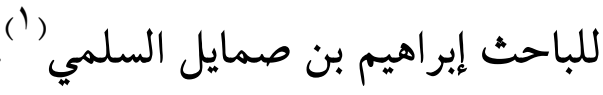

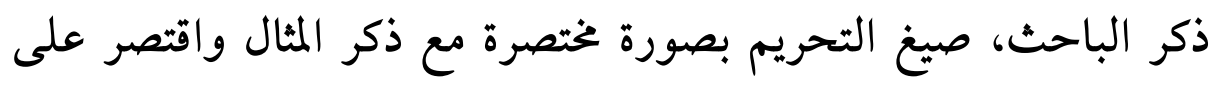

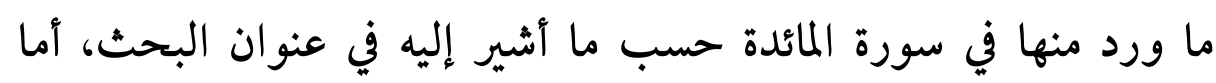
هذه الدراسة التي أقدمها فقد زادت على البحث المتقدم بما يأتي :

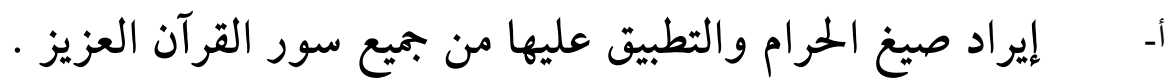

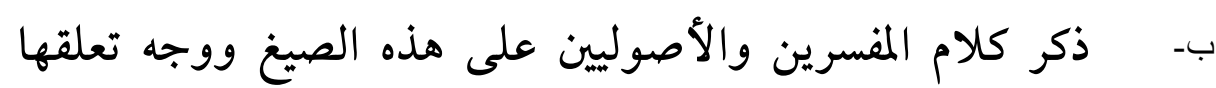
بالآية الكريمة .

تـ - إيراد القراءات القرآنية إذا دلت على صيغة الحرام أو أفادت

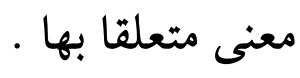
ثـ إضافة جملة من القواعد والضوابط المتعلقة بالحرام في القرآن

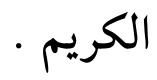

(1) رسالة ماجستير، قدمت لجامعة أم القرى، بتاريخ البع اهـ. 


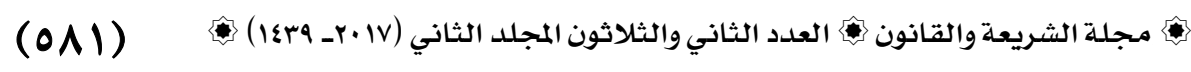
خطة البحث: - ت مجله

قسمت البحث إلى مقدمة، وأربعة مباحث، وخاتمة:

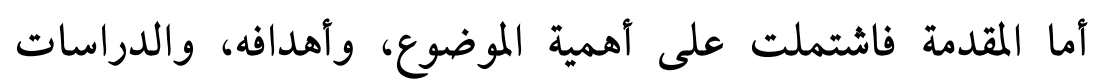
السابقة، وخطة البحث، ومنهج البحث.

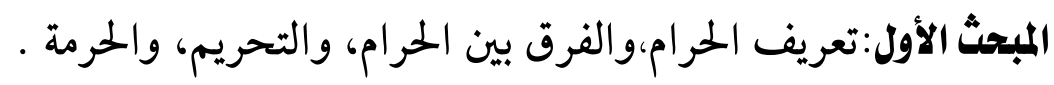

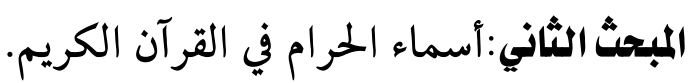

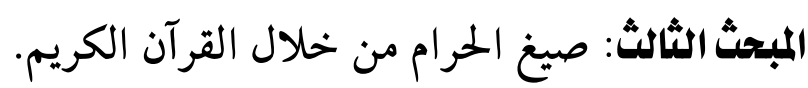

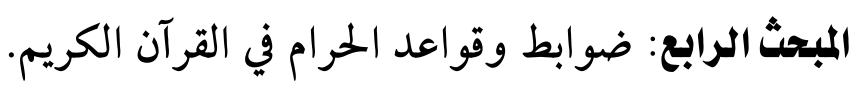

الخاتثة والتوصيات.

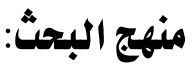

اتبعت المنهج الاستقرائي، والتحليلي، وكان المنهج على النحو الآتي:

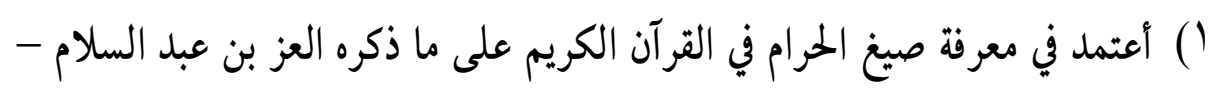

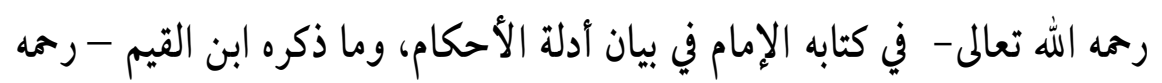

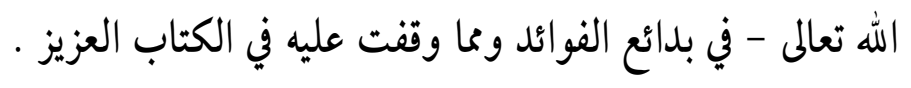
r أذكرصيغ الحرام،ثم أبين كلام الأصوليين على هذه الصيغة.

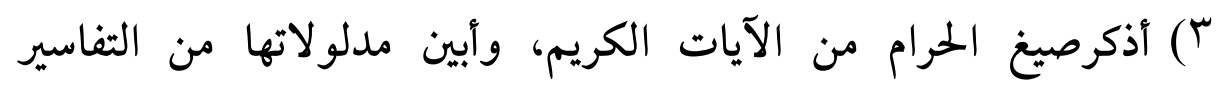
المعتبرة،ومما ذكره أئمة التفسير.

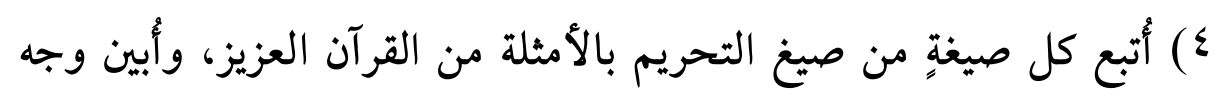
هذه الصيغة. ه) أورد القراءات القرآنية إذا دلت على صيغة الحرام، أو أفادت معنى" متعلقاً 
(OAY)

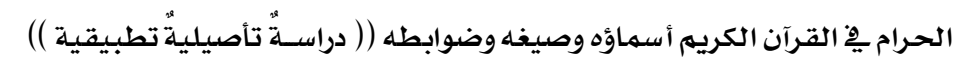

$$
\text { T) أعزو الآيات إلى سورها وأرقامها. }
$$

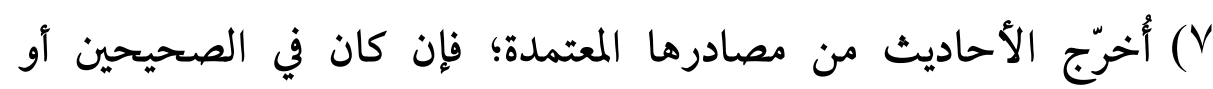

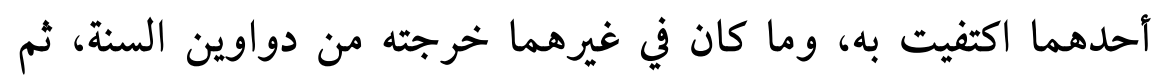

$$
\text { أذكر حكم أهل العلم عليه. }
$$

^) الم أثترجم للأعلام بغية الاختصار. 9) أُعرف بالمصطلحات التي تدعو إليها الحاجة. • ( ) أضع الفهارس العلمية وفق الآتي:

$$
\text { - - - فهرس المصادر والمراجع. }
$$

هذا وأسأل المولى الإخلاص والسداد في القول والعمل، وأرجو الله عز وجل أن يجعلني من يعمل بكتابه ويوفق لخدمته. 


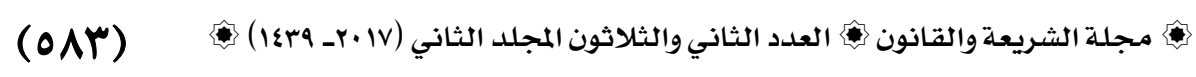

المبحث الأول: تعريف الحرام، والفرق بين الحرام، والتحريه، والحرمة . المطلب الأول : تعريف الحرام .

أولاً: الحرام لغة.

الحَرامُ، والحِرْمُ بالكسر في اللغة: الممنوع، يقال: محروم ومرزوق، وحرمه الشيء

ليُحْرمُه، حِرماً إذا منعه إياه (1).

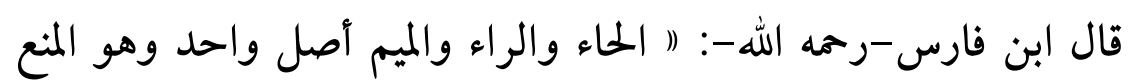

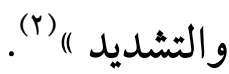

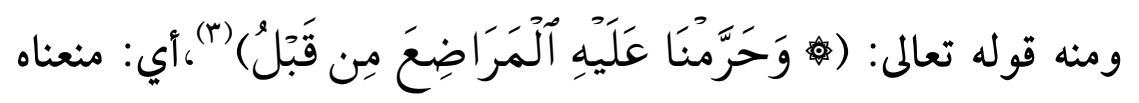

من أن يرتضع من المرضعات، أو حرمناه رضاعهن ومنعناه منهن إذ لم يكن

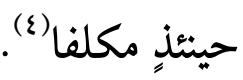

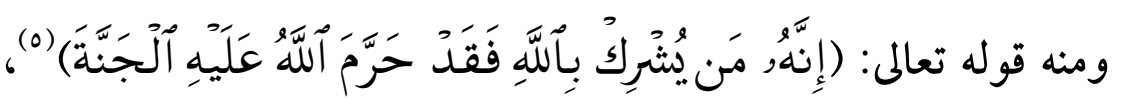

أي: يمنع من دخول الجنة (؟).

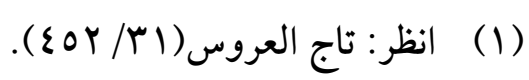

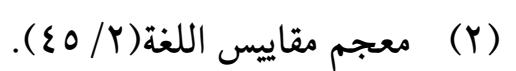

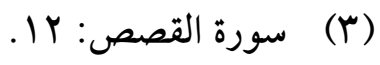

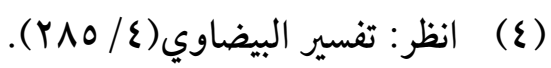

$$
\begin{aligned}
& \text { (0) سورة المائدة: VY. }
\end{aligned}
$$

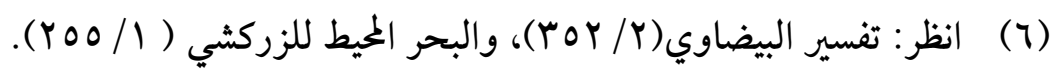


$(0 \wedge \varepsilon)$ الحرام هٌِ القرآن الكريم أسماؤه وصيغه وضوابطه (( دراسـةٌ تأصيليةّة تطبيقية ))

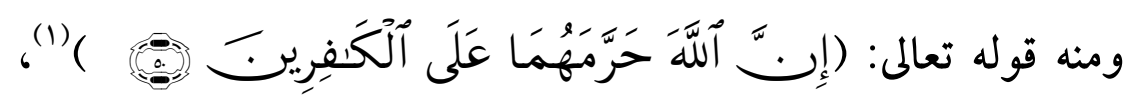

$$
\begin{aligned}
& \text { أي منع طعام الجنة وشرابها على الكافرين '. } \\
& \text { ومن مرادفات الحرام في اللفة: } \\
& \text { ا - المخظور: يقال: حظر الشيء عليه : منعه (r). }
\end{aligned}
$$

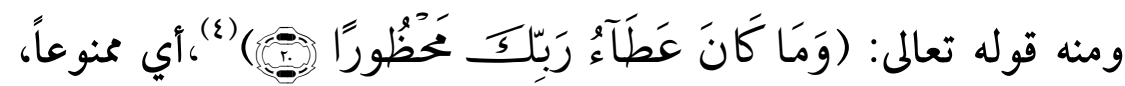

يقال: حظره يجظره حظراً: منعه، وكل ما حال بينك وبين شيء فقد حظره

عليك (0).

وفرق بعض أهل اللغة بين الحرام، والمحظور. قال أبو هلال العسكري:

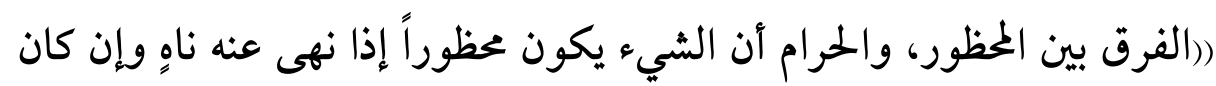

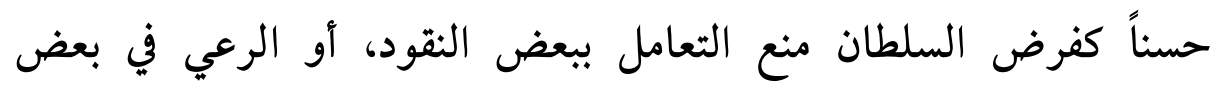

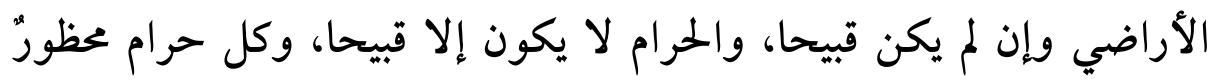

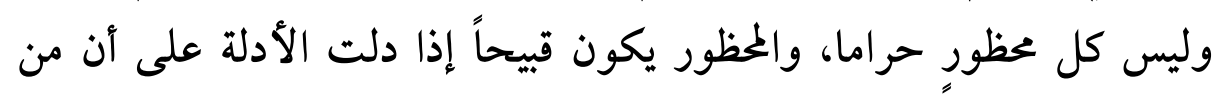

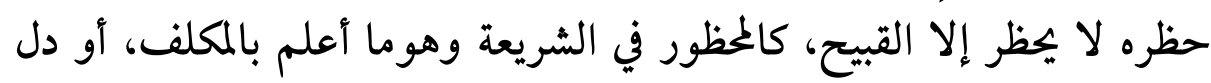
على قبحه، ولهذا لا يقال: إن أفعال البهائم محظورة وإن وُصفت بالقبح)، (1).

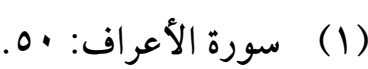

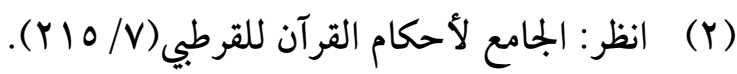

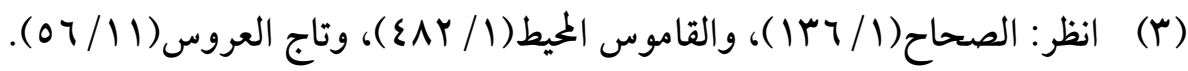

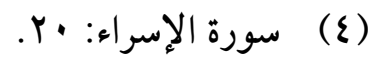

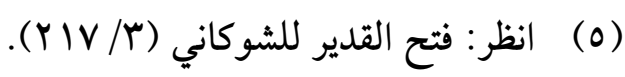

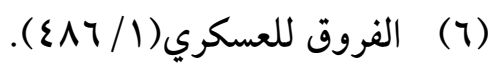




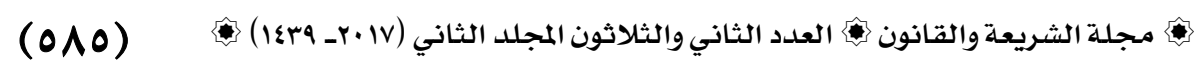

وقيل: إن الحرام يكون مؤبداً، والمُظور قد يكون إلى غاية (1).

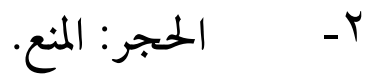

الحجُرُ: بالضم والكسر والفتح: الحرام، والكسر أفصح (r) المقال في

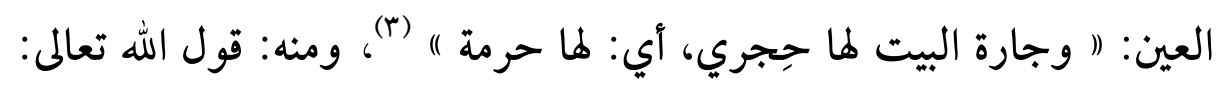

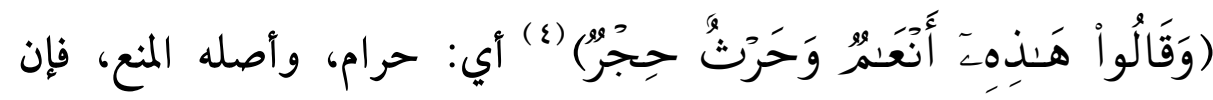

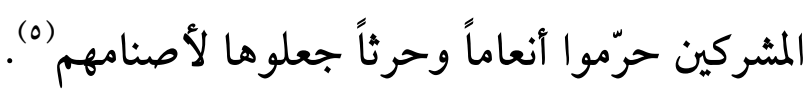

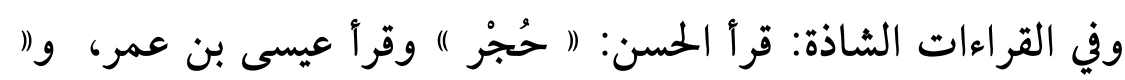
حُجُر" )، وجميعها لغات بمعنى واحد وهو الممنوع والحرام (T).

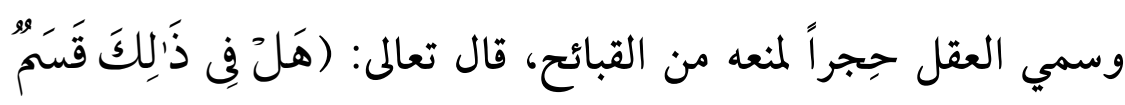

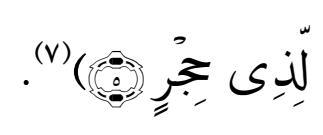

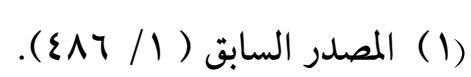

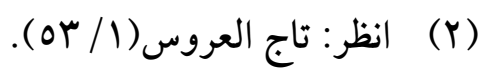

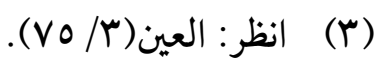

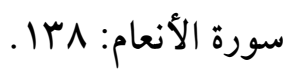

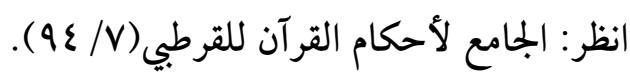

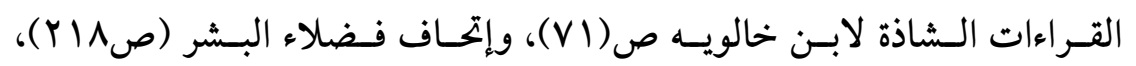

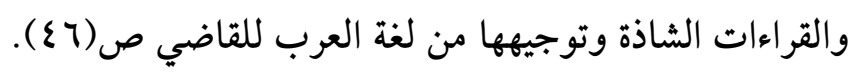

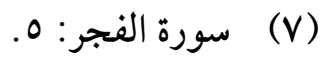


(O^Y)

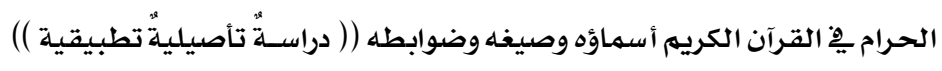

ويطلق الحرام على الواجب، ومنه قوله تعالى: (وَحَرَمُ عَلَّنَ قَرَيَةٍ

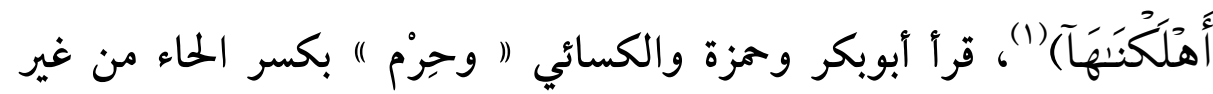

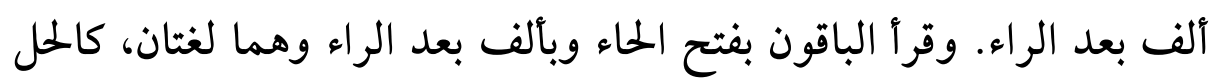

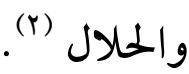

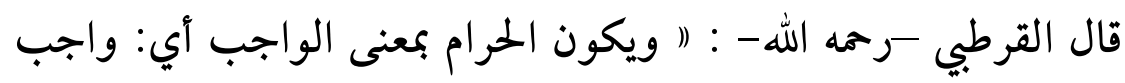

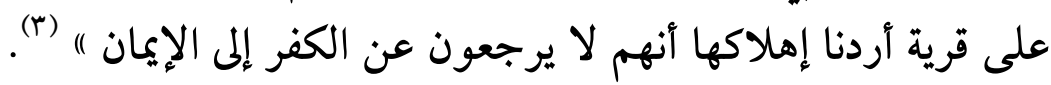

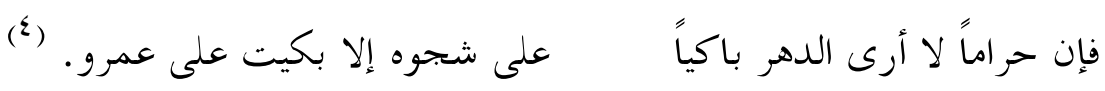

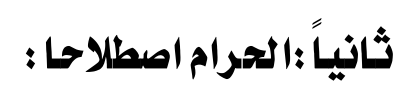
تعددت تعاريف الأصوليين لمصطلح الحرام فمنها تعريفالآمدي - رمثه

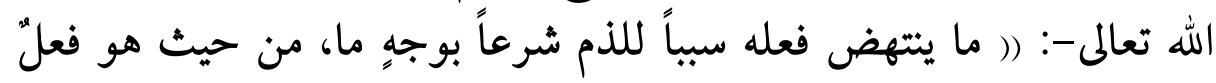

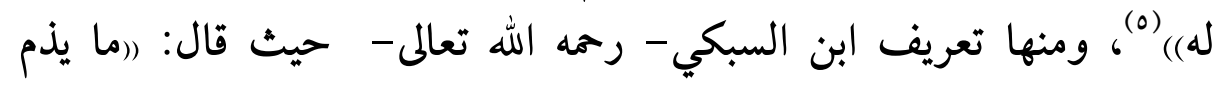

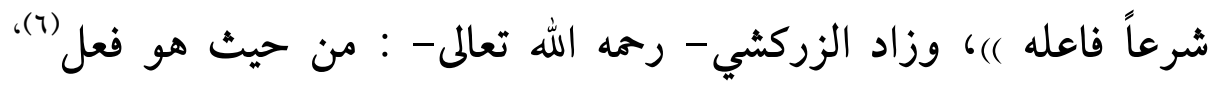

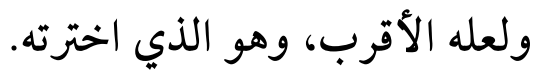

$$
\text { سورة الأنبياء: } 90 .
$$

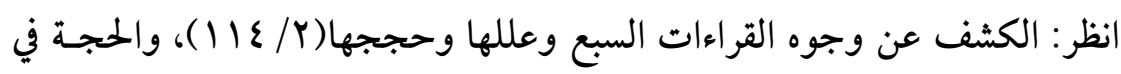

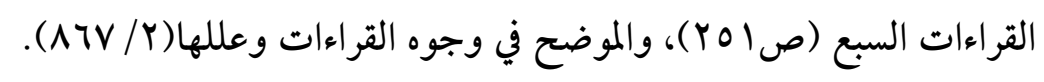

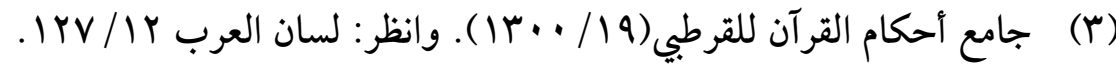

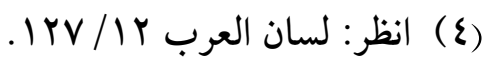

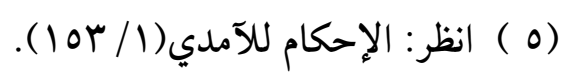

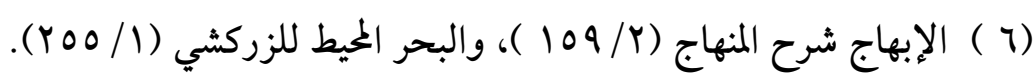




$$
\text { شرح التعريف :- }
$$

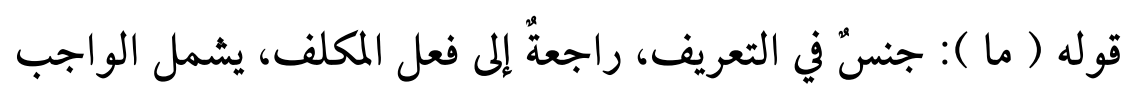

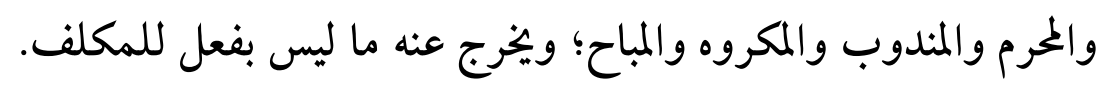

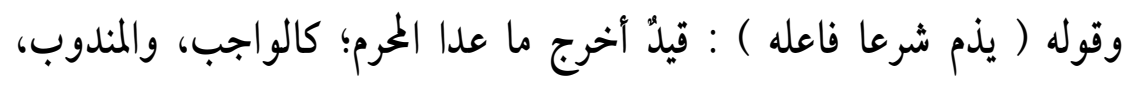

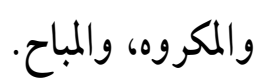

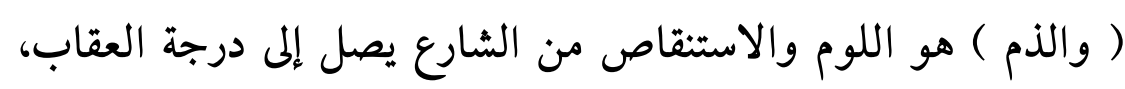

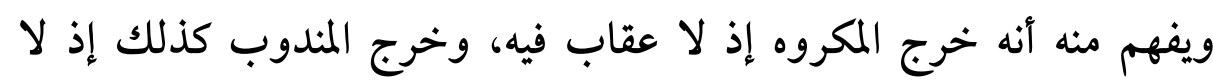

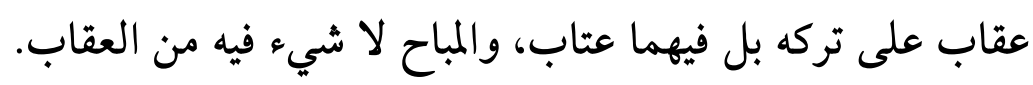

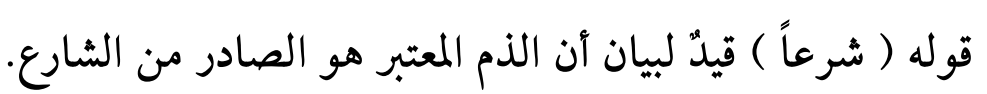
قوله ( فاعله ) قيدٌ خرج به الواجب؛ لأنه يذم على تركه. وقوله ( من حيث هو فعل ) خرج به المباح إذا استلزم تركه واجبا، فإنه يُذم عليه لكن من جهة أنه ترك واجبا (1).

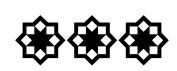

(1 ) انظر: نفائس الأصول / / / IV، وأصول الفقه لأبي النور زهير (1/ (0). 
(O^A)

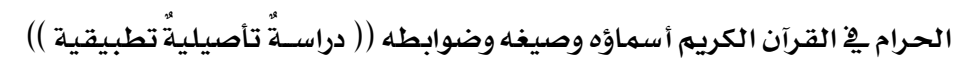

\section{المطلب الثاني : الفرق بين الحرام، والتحريه، والحرمة.}

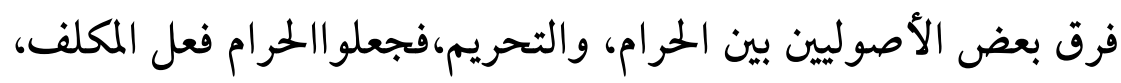

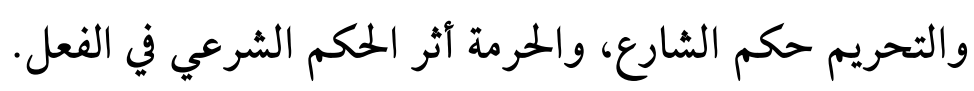
وبعض من الأصوليين تجوّز في إطلاق هذه المصطلحات بعضها على لى بعض.

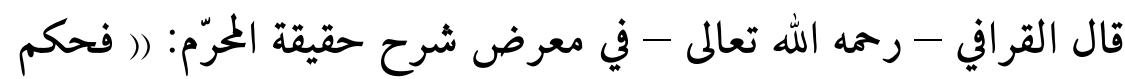

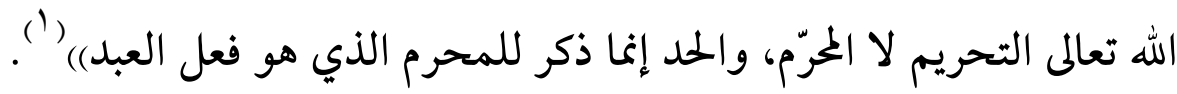
وقال شيخ الإسلام - رحمه الله تعالى -: (ر قد يقال: الحكم هو خطاب

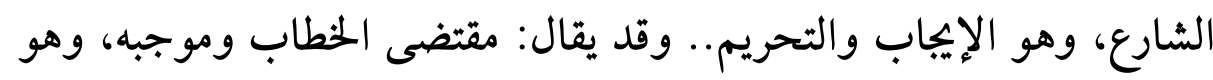

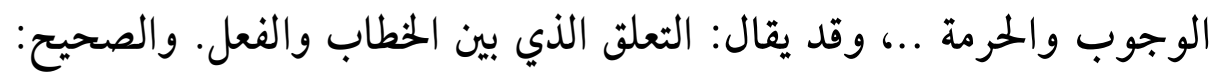
أن اسم الحكم الشرعي ينطبق على هذه الثلاثة )) (r). ومن تجوّز وتسامح في إطلاق التحريم والحرام والحرمة بعضها على

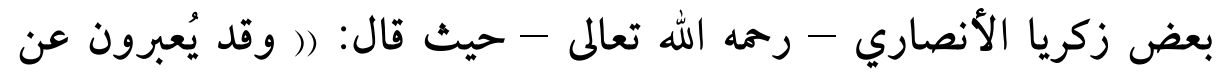

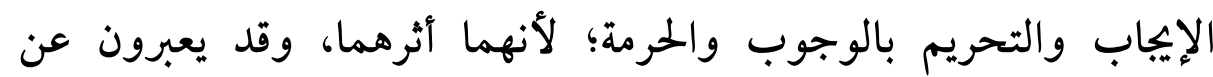

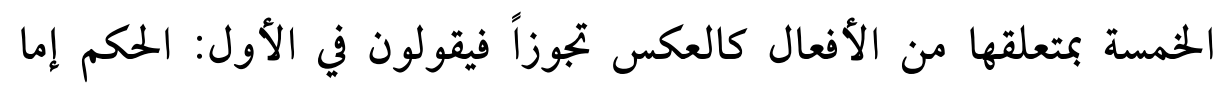

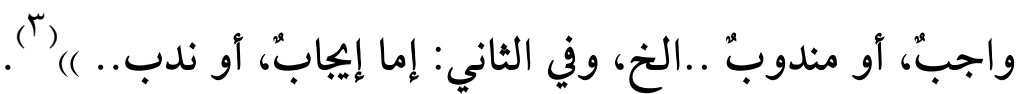

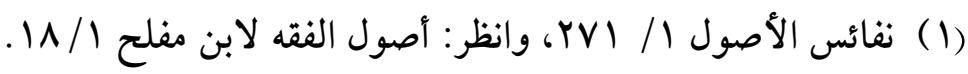
(r)

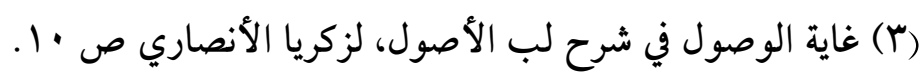




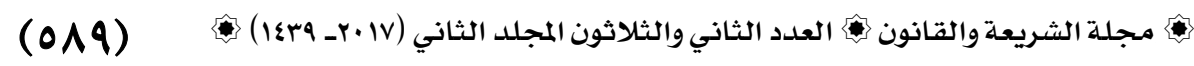

وقال العطار - رحمه الله تعلى - في حاشيته على شرح المحلي: (ر قوله:

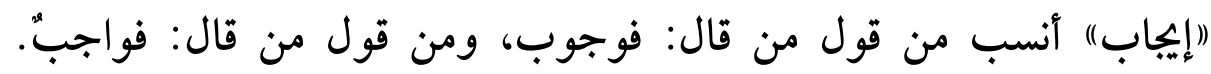

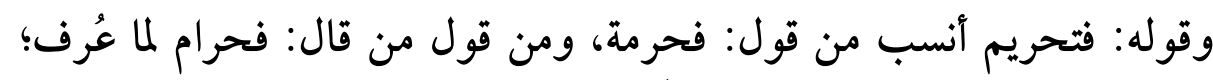

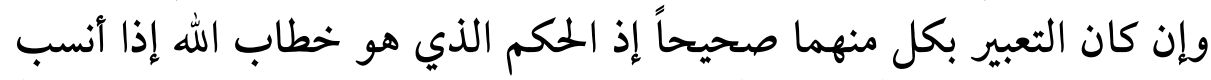

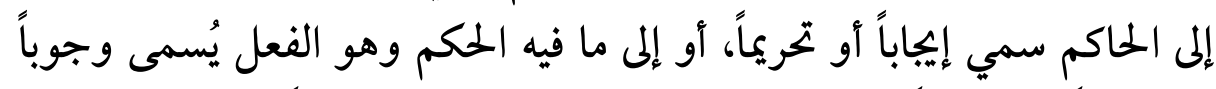

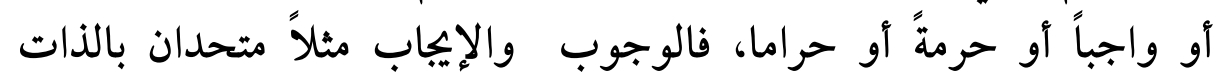
مختلفان بالاعتبار..()) (').

ويمكن أن يقال: إن من عرّف الحكم الشرعي بأنه خطاب الله - تعالى -

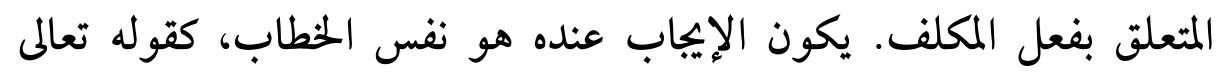

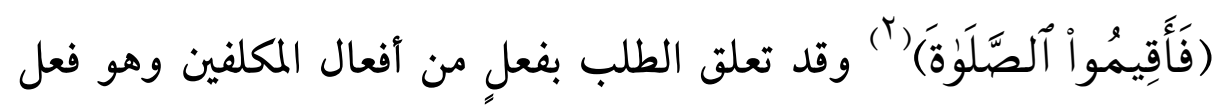
الصلاة المفروضة فجعله واجبا. والتحريم عنده هو المستفاد من هذا الخطاب وأثره، كقوله تعالى (وَلَا تَقَتُلُوُاْ

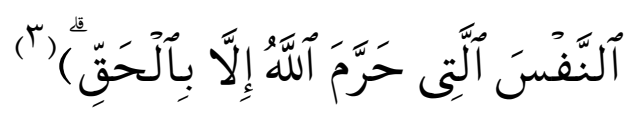

فقد تعلق الخطاب بفعلٍ من أفعال المكلفين وهو قتل النفس فجعله

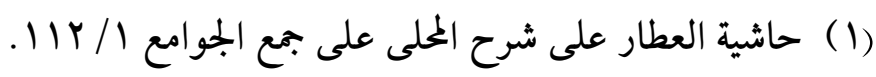

$$
\begin{aligned}
& \text { (r) سورة الحج: (Y) ساشية العطار على } \\
& \text { (Y) سورة الإسراء: بr. }
\end{aligned}
$$

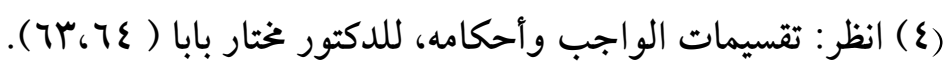




\section{المبحث الثاني: أسماء الحرام في القرآن الكريم.}

إن الأسماء والمصطلحات الشرعية التي أوحاها الله إلى رسوله الثئي

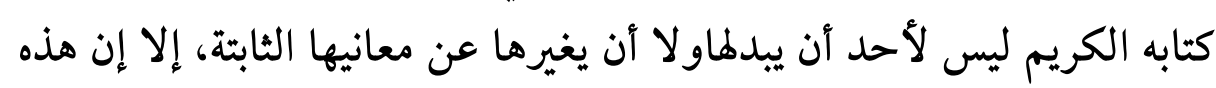

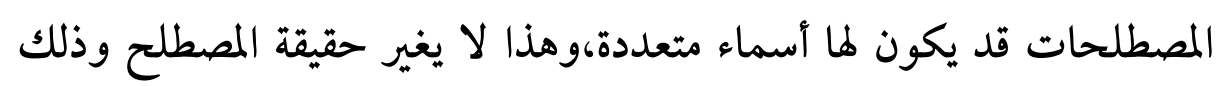
أن المعنى واحد، قالالفتوحي -رحمه الله- : " ويسمى - يعني الحرام - مخظوراً،

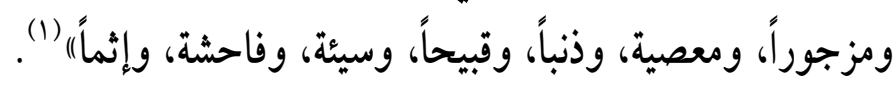

\section{ولقد ورد في القرآن الكريه بإطلاقات متعددة، منها:}

ـ المعصية: مرادفة للمحرم، قال الرازي: (" وأسماؤه كثيرة، أحدها: أنه

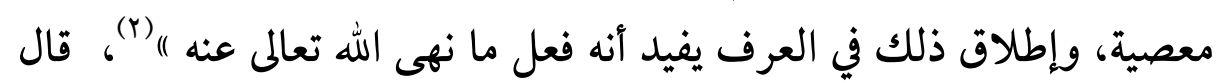

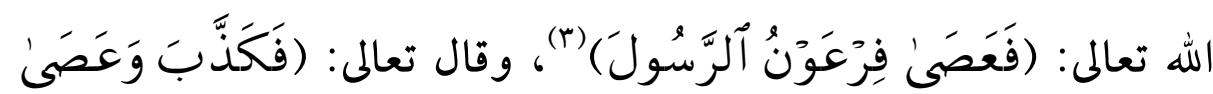
(2) (2) ومعنى الآيتين أن فرعون كذّب الرسول الذي أرسله اللهإليه ولم يؤمن به، وكذّب وعصى الله عز وجل بعد ظهور المعجزات، وهذا هو حقيقة الحرام (0)

$$
\begin{aligned}
& \text { (1) (1) التحبير شرح التحرير (1) (1) (1) (1). }
\end{aligned}
$$

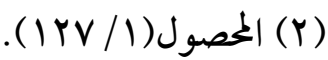

$$
\begin{aligned}
& \text { (Y) (Y) سورة المزمل: } 17 .
\end{aligned}
$$

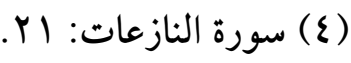

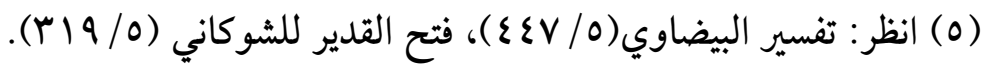




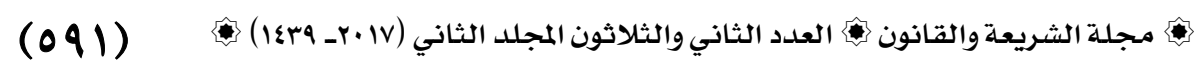

ـ الذنب: يطلق على الحرام في القرآن الكريم وهو من أسمائه، قال

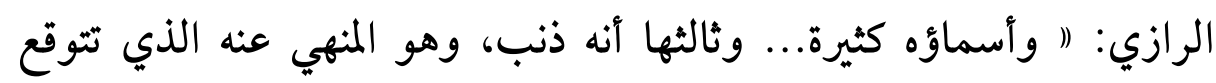

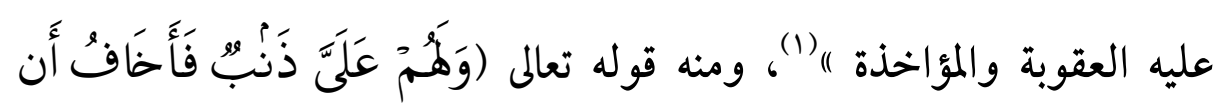

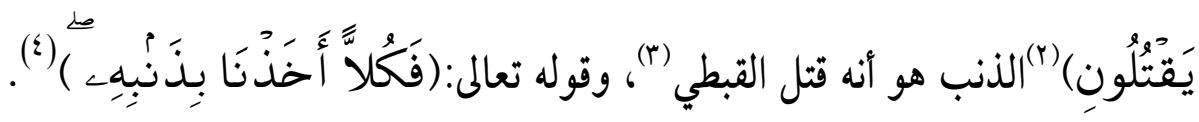

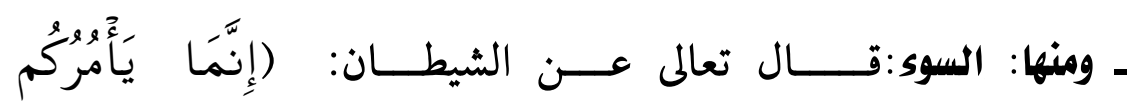

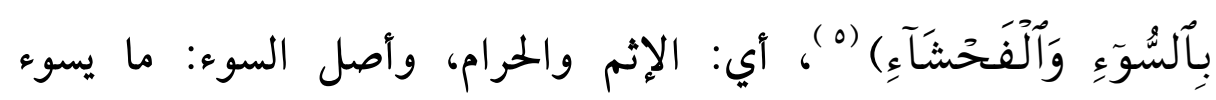
صاحبه

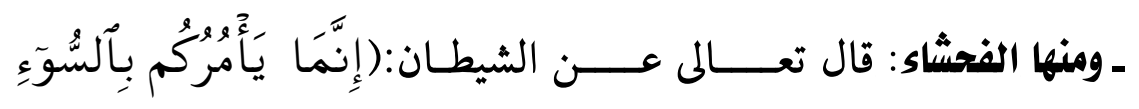
وَأَلْفَحَشَاَعِ) (v)

ومعنى الفحشاء المعاصي والمحرمات وما قبح من القول والفعل (A).

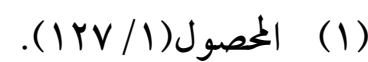

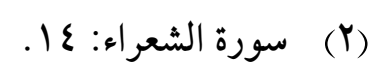

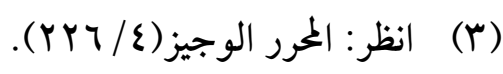

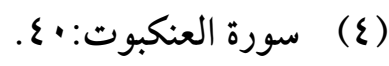

$$
\begin{aligned}
& \text { (0) سورة البقرة: } 179 .
\end{aligned}
$$

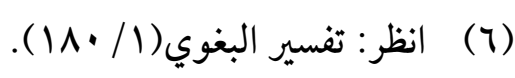

$$
\begin{aligned}
& \text { سورة البقرة: (V) } 179 .
\end{aligned}
$$

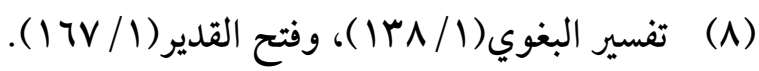




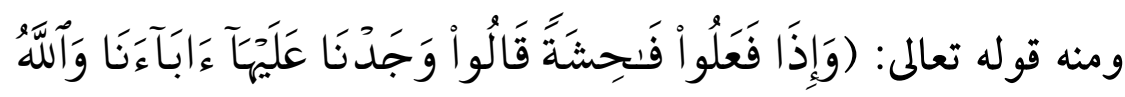

$$
\text { (1) }
$$

والفاحشة هنا لفظ عام يشمل المحرم بجميع أنواعه، إلا أنه يقصد به في

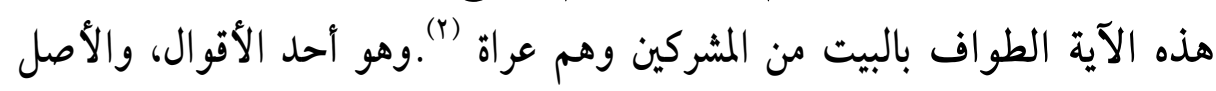
عموم فواحش أهل الجاهلية؛لسياق الآية.

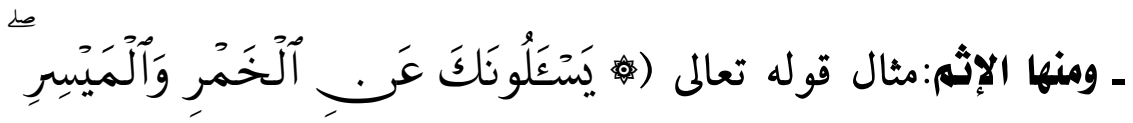

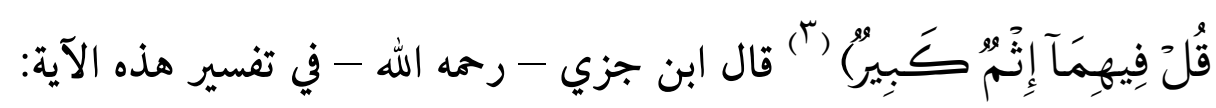
( نصن" في التحريم وأنهما من الكبائر؛ لأن الإثم حرامُ لقوله تعالى (قُلْ إنَّمَا

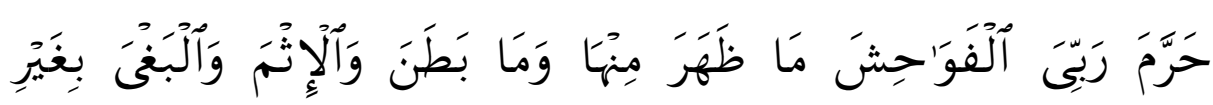

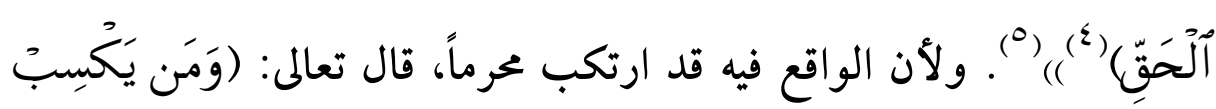

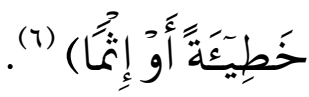

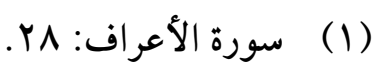

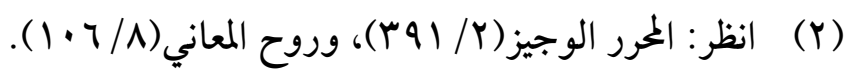

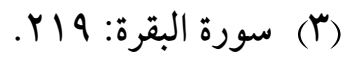

$$
\begin{aligned}
& \text { (ع) سورة الأعراف: بالبه }
\end{aligned}
$$

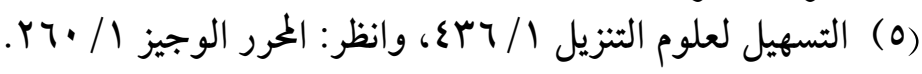

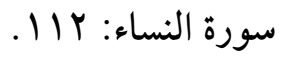




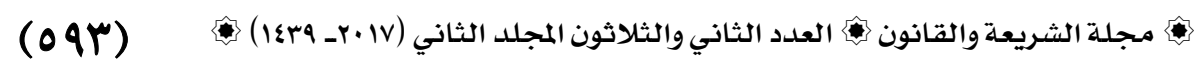

وقوله تعالى: (إثمَّاً):كسب كبيرة أو ما كان عن عمد، أو ذنب، وهذا هو معنى

الحرام (1)

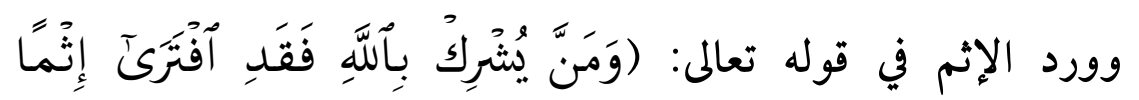

عَظِيمَاً) (r) أبي:كذب كذباً عظيماً استحق عليه عذاباً أليماً، والحقيقة أن هذا

التفسير هو معنى الحرام، فالكذب على الله تعالى هو من أعظم الحرام (r).

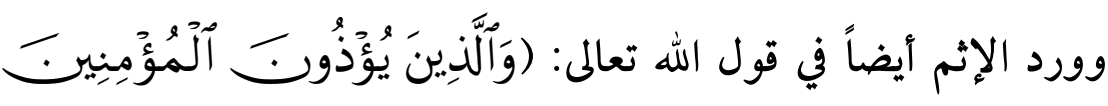

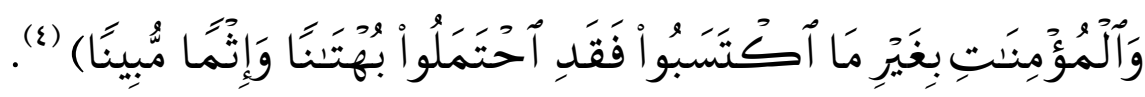
وتفسير هذه الآية: أن من آذى المسلمين بغير جناية منهم فقد احتملوا على ظهورهم بهتاناً وإثماً مبيناً؛ حيث تعدوا عليهم، وانتهكوا حرمة أمر الله باحترامها، فالإثم هنا بمعنى الحرام (0)

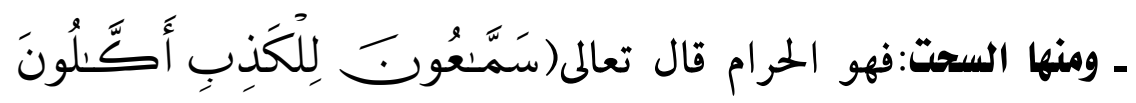
لِلسُّحُتِّ) (ج)فقدفسرابن جزي - - رحمه الله تعالى -السحت بالحرام، قال في

$$
\begin{aligned}
& \text { (1) انظر: التسهيل لعلوم التنزيل(Y/ • (1) )، وفتح القدير(1/ (1/ ) ). }
\end{aligned}
$$

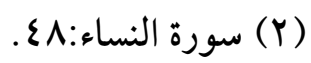

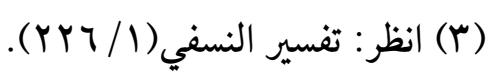

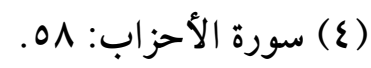

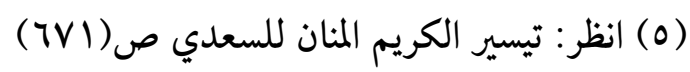

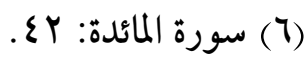




\section{(०१६)}

الحرام مِّف القرآن الكريم أسماؤه وصيغه وضوابطه (( دراسـةٌ تأصيليةّ تطبيقية ))

التسهيل لعلوم التنزيل: (( أي للحرام؛ من الرشوة والربا وشبه ذلك )) (1).

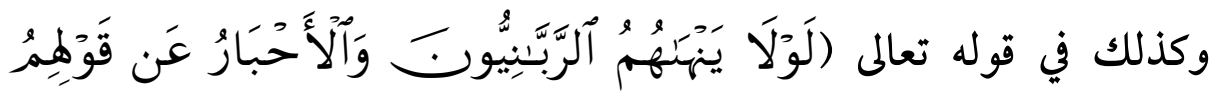

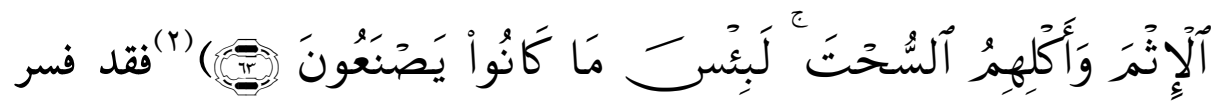
السحت هنا أيضاً بالحرام (r). ـ ومنها المكروه:قال الآمدي-رمامه الله تعالى- عن مصطلح المكروه: "

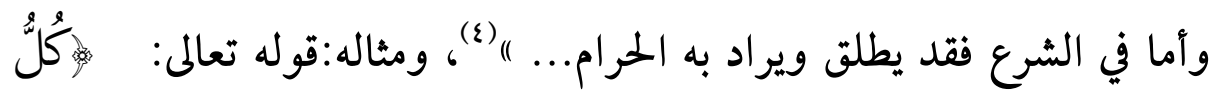

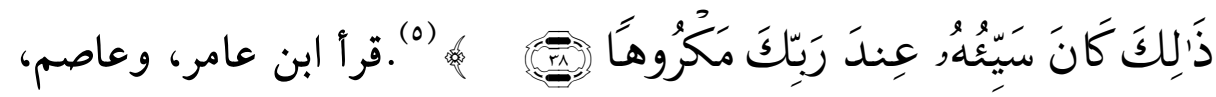
ومزة والكسائي، وخلفبضم الممزة والماء على الإضافة(")، ومعناه: كل الذي لِّي

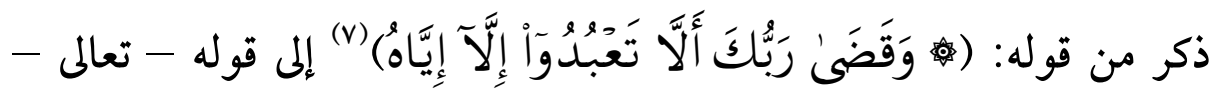

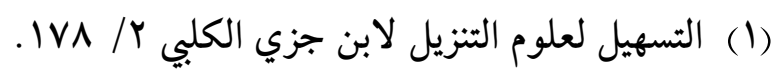
(r) سورة المائدة: كا.

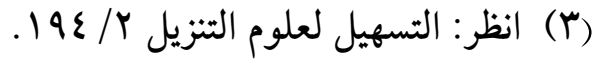

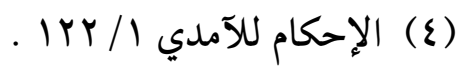
(0) سورة الإسراء: بـ. (T) انظر: النشر في القراءات العشر r V/r.r. (V) سورة الإسراء: لr. 


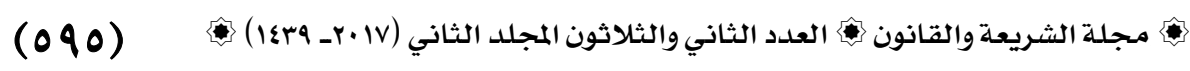

(كَانَ سَيِيُعهُور) أي :سيءماعددناعليك عند ربك مكروهاً؛ لأنه قد عدّ أموراً حسنة،

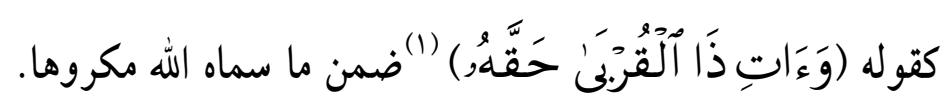

وقرأ ابن كثير، ونافع، وأبو عمرو، وأبو جعفر - رحمهم الله تعالى - دكل

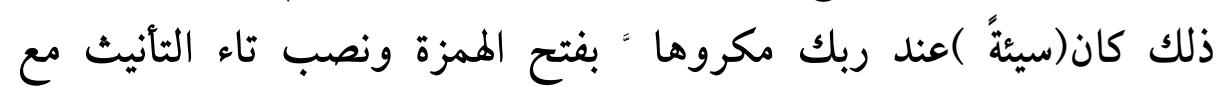
التنوين علي التوحيد (r)، يعني كل الذي ذكرنا من قوله (وَلَالَ تَقْتُلُوَاً أَوَلََدَكُمُم) (r) إلى هذا الموضع سيئة لا حسنة فيه؛ إذ الكل يرجع إلى المنهي عنه

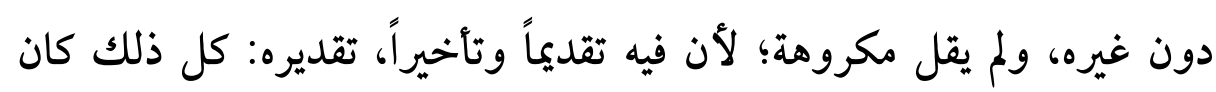

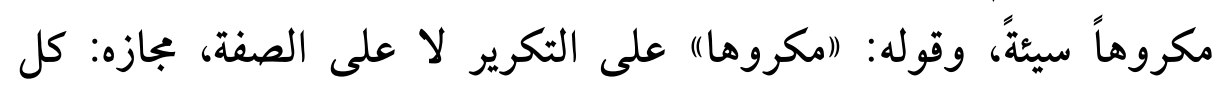

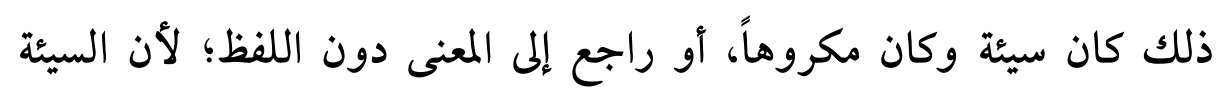

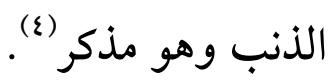

$$
\begin{aligned}
& \text { (1) سورة الإسراء: جr. (1) }
\end{aligned}
$$

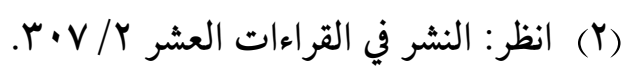

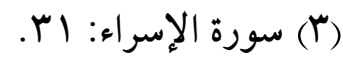

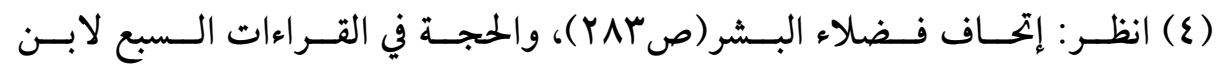

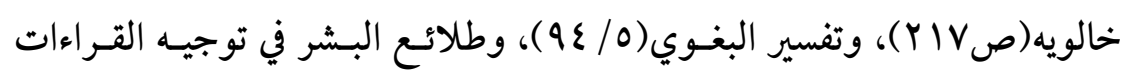

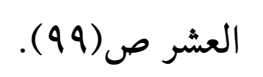


وقال ابن جزي الكلبي-رحمه الله- : ( الإشارة إلى ما تقدم من المنهيات

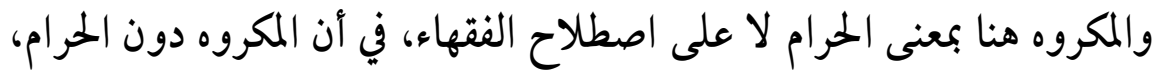

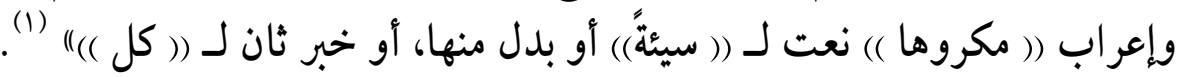

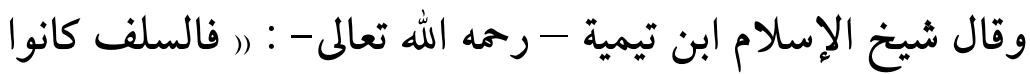

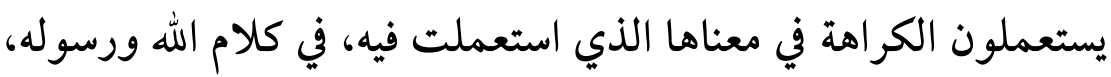

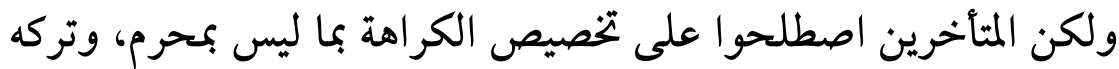

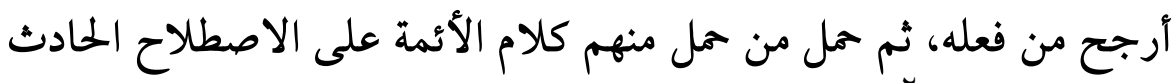

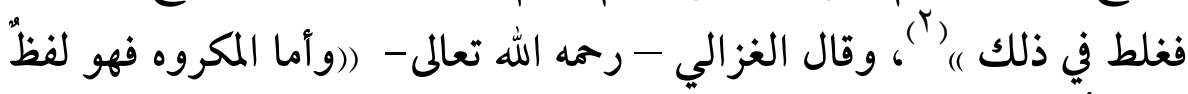

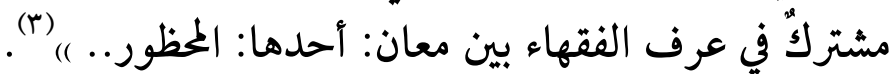

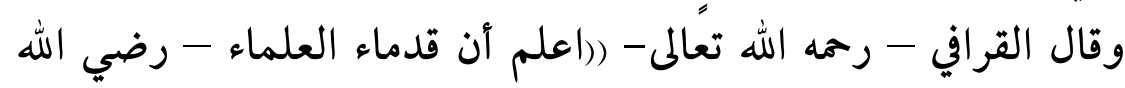

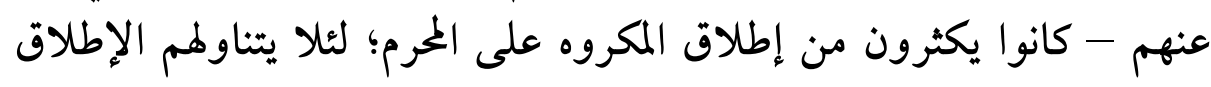

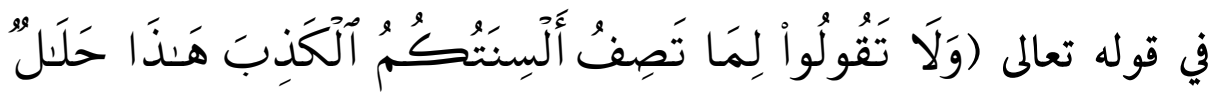

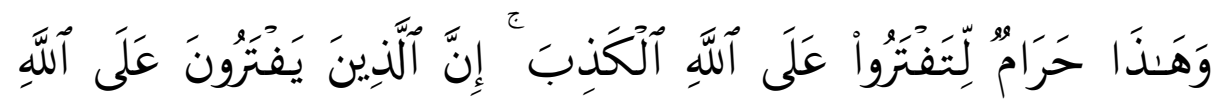
ألْكَذَبَ لَا يُفْلِحُونَ) (ع) فيحددون صورة اللفظ، وإن لمُ يرد إلا في تحريم ما لم يحرمه الله كالسائبة ونحوها )( ).

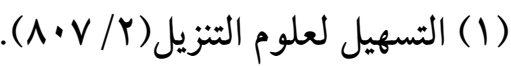

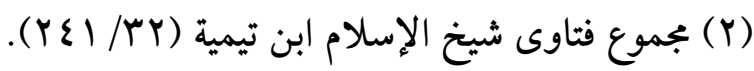

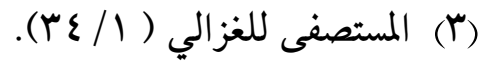

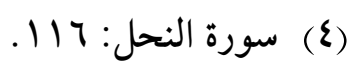
(0) نفائس الأصول IV/V (8) 


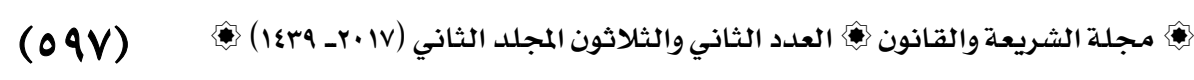

وقال المرداوي - رحه الله - في التحبير شرح التحرير: (ر يطلق المكروه

ويراد به الحرام، وهو كثيرّ في كلام الإمام أمد، وغيره من المتقدمين)( '). 
(094) الحرام هِّ القرآن الكريم أسماؤه وصيغه وضوابطه (( دراسةٌّة تأصيليةٌ تطبيقية ))

\section{المبحث الثالث: صيخ الحرام من خلال القرآن الكريم.}

هناك أساليب وصيغ عدة تدل على مصطلح التحريم في كتاب الله

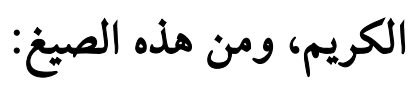

أولاً: صيغة النهي الدالة على طلب الكف عن الفعل إن لم يصرفها

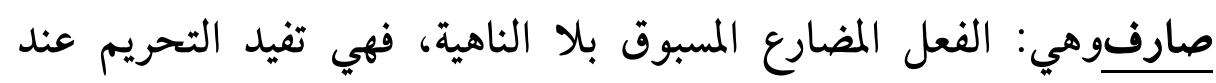

الجمهور (1)

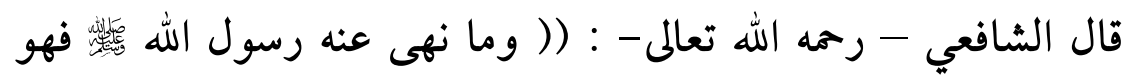

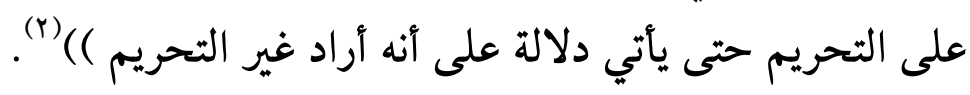

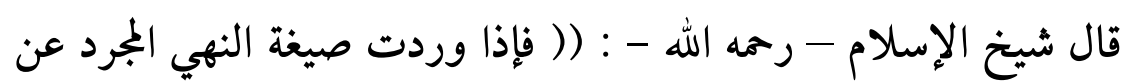

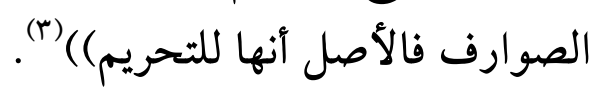

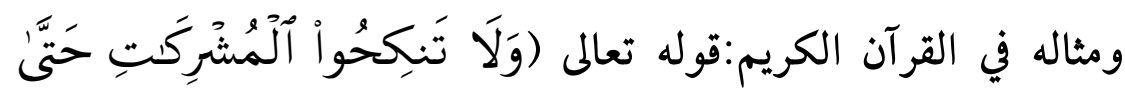

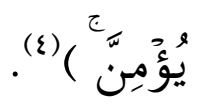

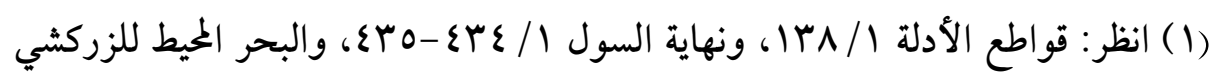

$$
\text { . } 2 \text { r } 7 / r
$$

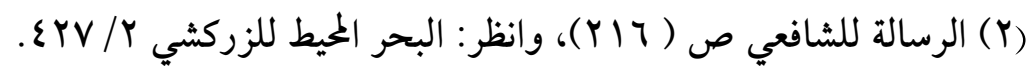

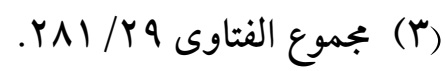

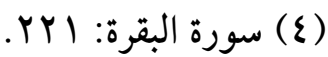




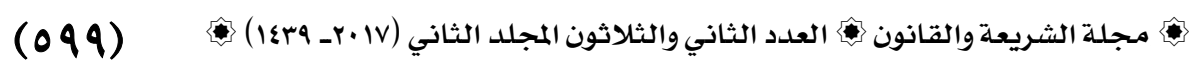

فصيغة:(رلا تنكحوا)تدل علىالنهي عن نكاح المشركات من عبدة

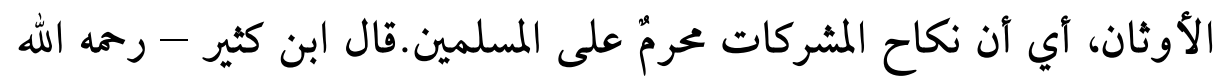

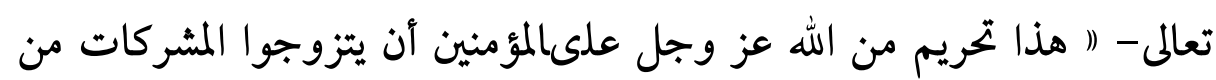
عبدة الأوثان ") (1)، قرأ الجممهور بفتح التاء (وَلَا تَنِكِحُواً) في الشاذ بضمها،

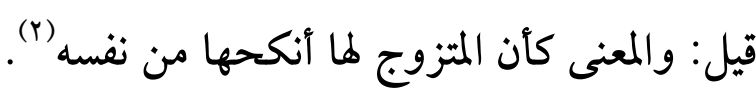

$$
\text { وعلى جميع الأحوال يحرم نكاح المشركة. }
$$

والأمثلة في القرآن الكريم على هذه الصيغة كثيرة.

\section{ثانياً: النفي الذي يفيد التحريه:}

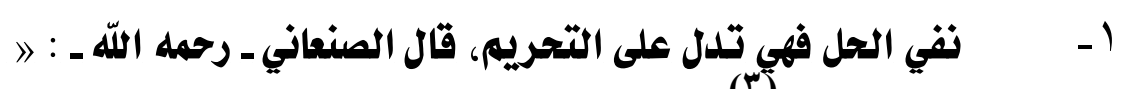

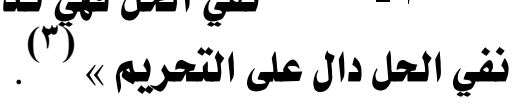

وردت هذه الصيغة في القرآن الكريم في أكثر من موضع، ومثاله:قوله

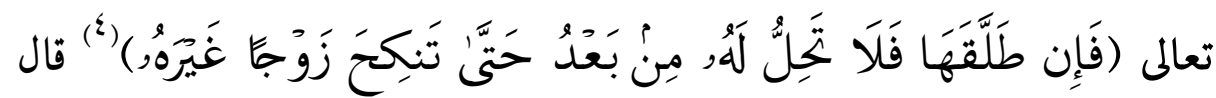

الطاهر ابن عاشور - رحمه الله تعالى- : وقوله (فَلَا تَحَلُّ)أي: تحرم عليه.. (0).

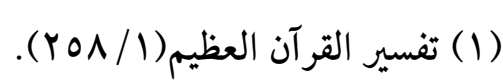

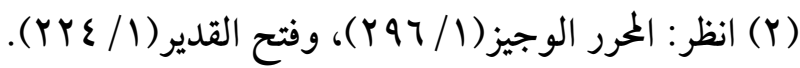

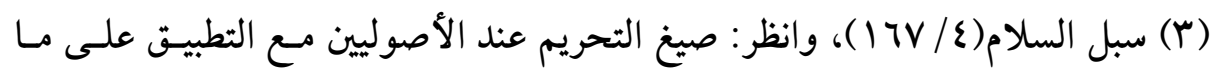

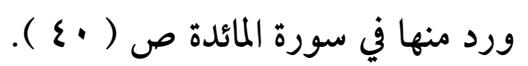

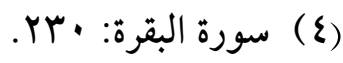

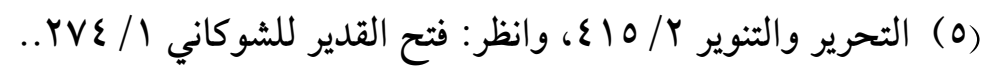


$(7 \cdot$. الحرام هٌِ القرآن الكريم أسماؤه وصيغه وضوابطه (( دراسـةُة تأصيليةّ تطبيقية ))

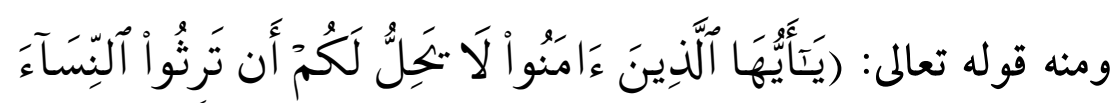
كَرْهًَا) (")،وحرم الله عز وجل أن تُجعل النساء كالمال يورثن عن الرجال كما

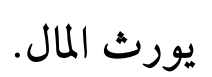

قرأ حمزة والكسائي (كُرهاً) بضم الكاف، وقرأ باقي السبعة بالفتح (؟). قال أبو عمرو - رممه الله تعالى- : بالضم كل شيء يكره فعله، وبالفتح ما

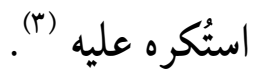

يقال: (رلتفعل ذلك طوعاً أو كرهاً يعني طائعاً أو مكرهاً، والخطاب

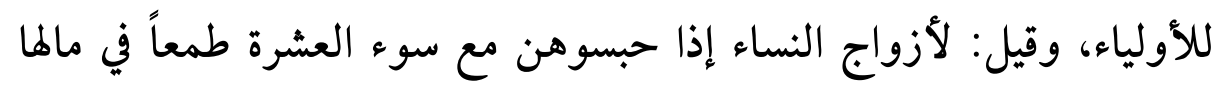
وإرثها () (ع)

فيلحظ أن هذا التحريم ثبت بنفي الحل فإن الله سبحانه قال:(لا يحل) الإباحة والحل يستلزم التحريم.

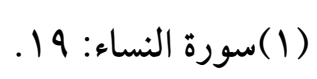

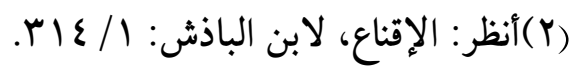

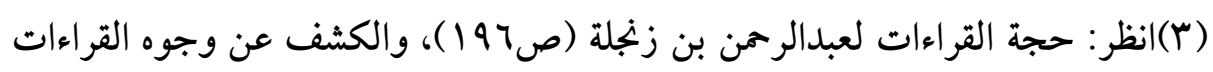

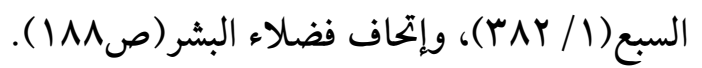

$$
\begin{aligned}
& \text { ( ) انظر: الجامع لأحكام القرآن للقرطبي(1) و (90). }
\end{aligned}
$$




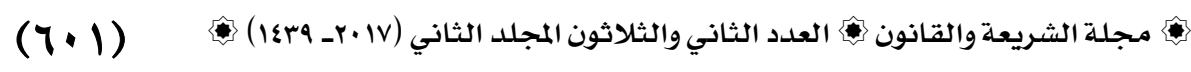

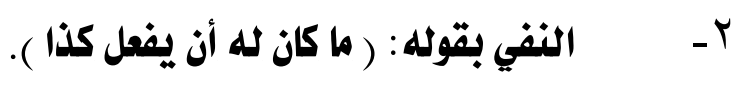

هذه الصيغة نفي” لاستحقاق أحدٍ لذلك القول، أو الفعل، وأصل هذا التركيب في

الكلام ما كان فلانٌ فاعلاً كذا (').

وقال ابن عطية - رحمه الله - (ر قوله تعالى: (وما كان) لفظه النفي ومعناه

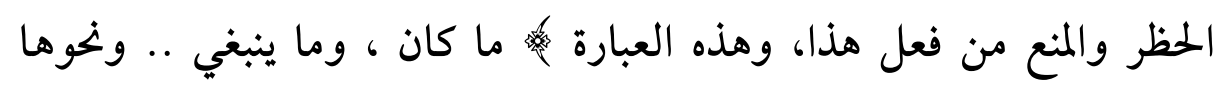

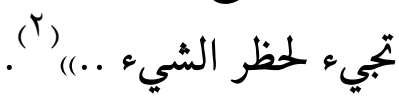

قال ابن القيم - رحمه الله - : (ر وأما لفظة: ما يكون لك، وما يكون لنا فاطرد

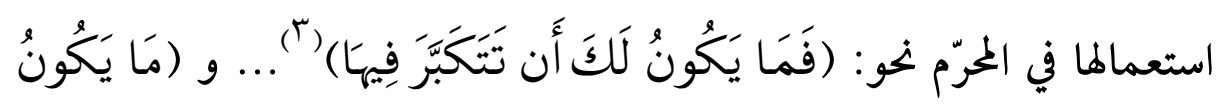

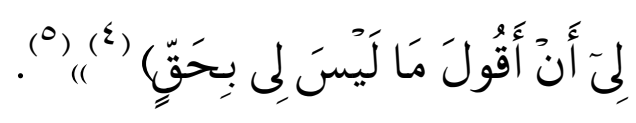

قال ابن عاشور - رحمه الله - عند تفسير قوله تعالى (فَمَا يَكُونُ لَكََّأن تَتَكَبََّ فِيهًا): ( ودل قوله (فَمَا يَكُونُ لَكَ) على أن ذلك الوصف لا يُعتفر منه؛ لأن النفي بصيغة ( ما يكون لك) كذا أشد من النفي بـ ( ليس لك كذا)

$$
\begin{aligned}
& \text { (1) انظر: التحرير والتنوير ؟ / به ؟. }
\end{aligned}
$$

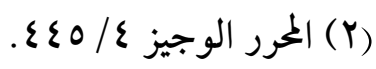

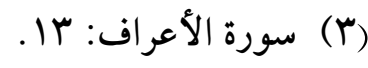

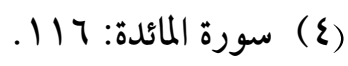

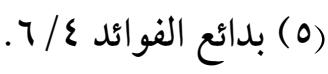


$(T \cdot Y)$

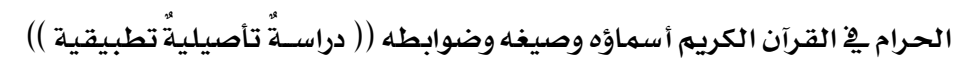

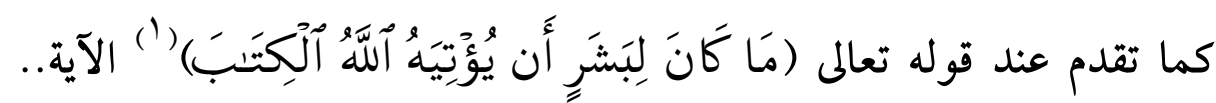
وهو يستلزم هنا نهياً؛ لأنه نفاه عنه مع وقوعه...(r) (r). قال الزركشي - رحمه الله تعالى -: (ر وقد يجيء النفي في معنى النهي، ويختلف حاله

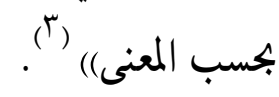

فإذا وردت في القرآن الكريم فإنها تدل على أنه يقصد بها التحريم (ع).

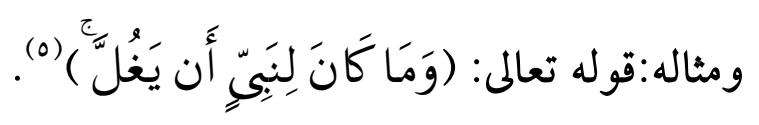

قرأ ابن كثير،وأبو عمرو، وعاصم أَن (يَغُلََّّ ) بفتح الياء وضم الغين (ج)، أي: لا يصح أن يقع من ببي غلول ألبتة، وقرأ باقي السبعة (أن يُغَل) بضم إنماء

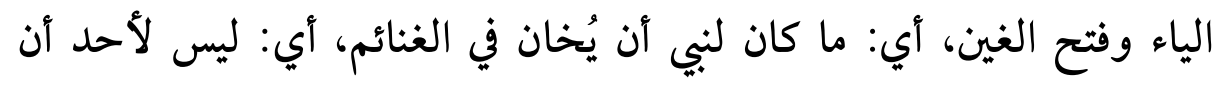

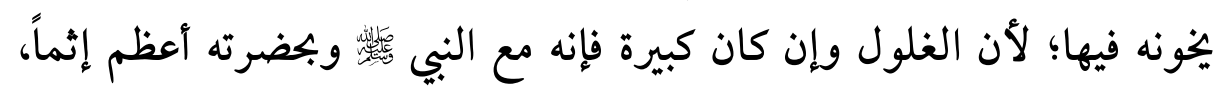

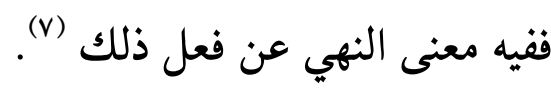

$$
\begin{aligned}
& \text { (1) (1) (1) سورة آل عمران: }
\end{aligned}
$$

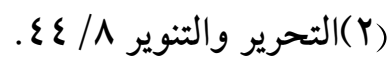

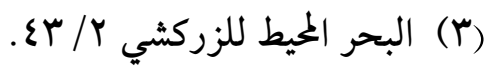

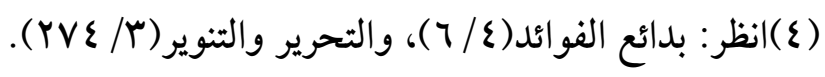

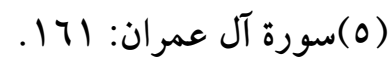

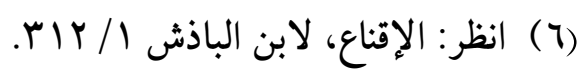

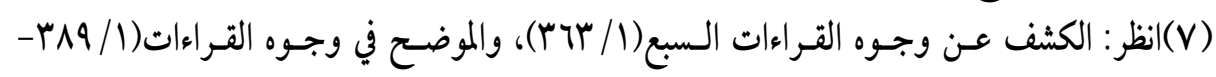

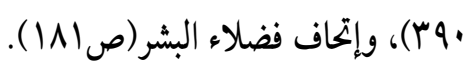




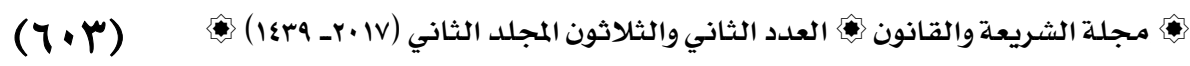

فهذه الصيغة صيغة نفي،"أكلكمكىكيلمُوقد أفادت النهي، والنهي

يقتضي التحريم '(1).

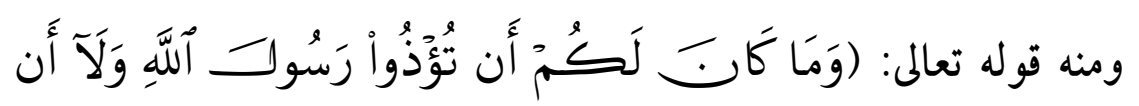

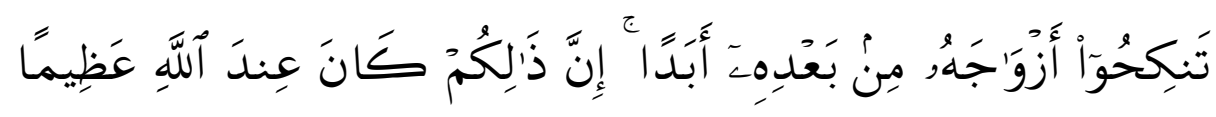

$$
(\text { (r) (a) }
$$

قال الطاهر ابن عاشور - رحمه الله - : (ر ودلت على الحظر المؤكد؛ لأن "أعمغغمة" نفي" للاستحقاق الذي دلت عليه اللام، وإقحام فعل كان لتأكيد

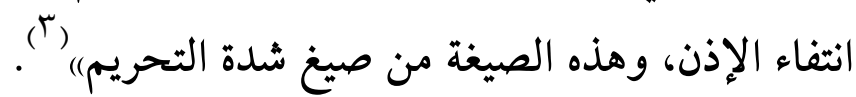

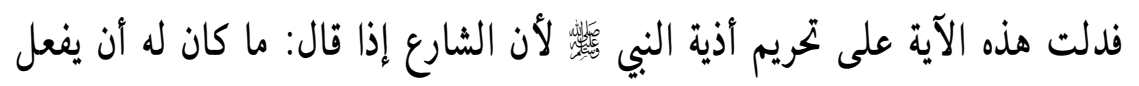
كذا فإنه نهي عنه. فالمراد أن كل ما منعتم عنه مؤذ فامتنعوا عنه، وهو هنا نكاح أزواج النبي

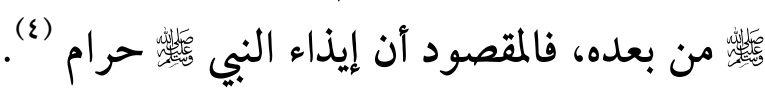

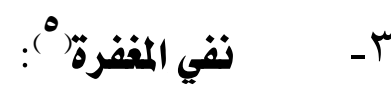

إذا نفى الله - عز وجل - المغفرة عن أحلٍ دل على أن هذا الفعل محرم.

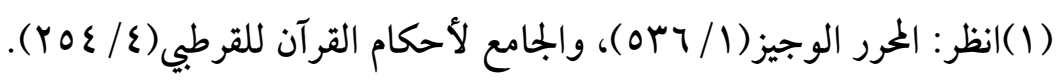

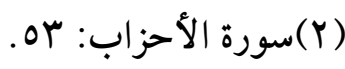

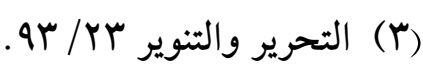

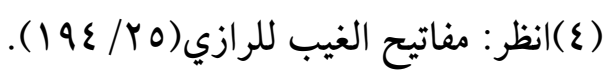

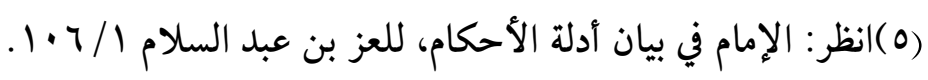




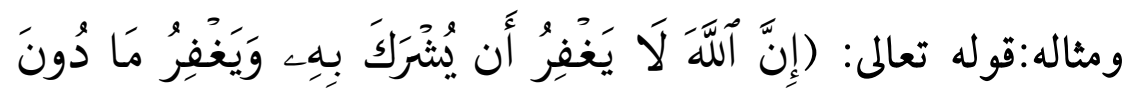

$$
\text { ذَبلِكَكَلِمَن يَثَاَعُ (1). }
$$

دلت هذه الآية على تحريم الشرك من خلال صيغة نفي المغفرة لمن

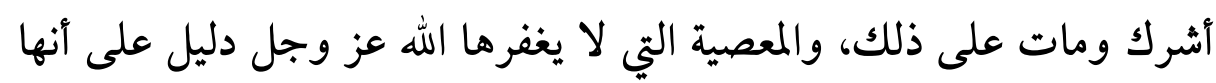
غاية في التحريم (r)

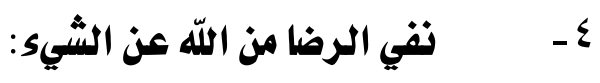

إذا نفى الله - عز وجل - الرضا عن فعلٍ أو عن فاعله فهي صيغةٌ تدل

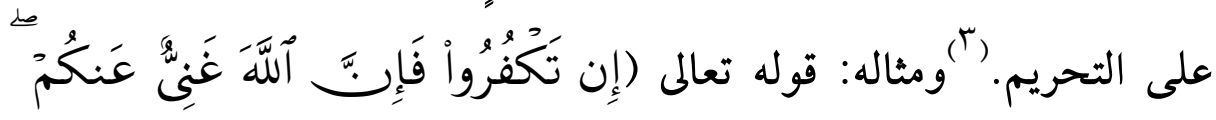

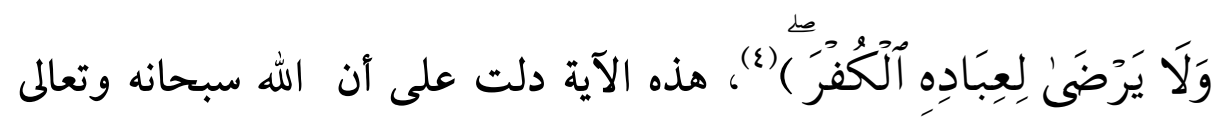
لا يرضى لأحد من عباده الكفر، ولا يحبه، ولا يأمر به (م)، ومنه قوله تعالى:

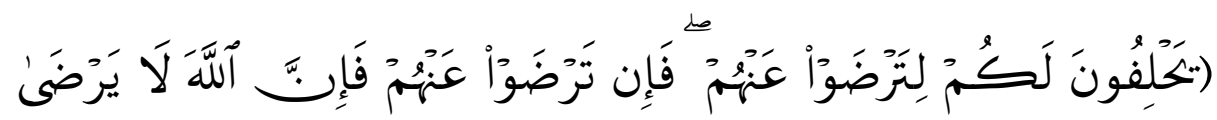

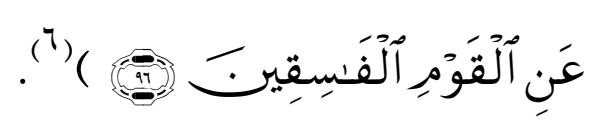

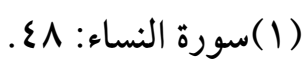

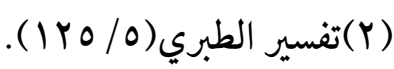

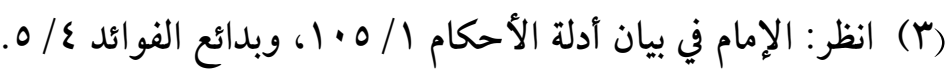

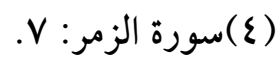

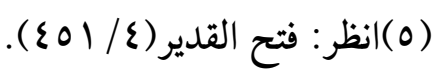

$$
\begin{aligned}
& \text { (7) سورة الثوبة: } 97 .
\end{aligned}
$$




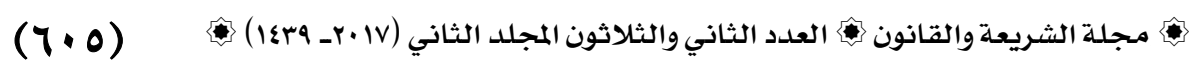

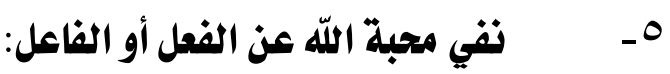

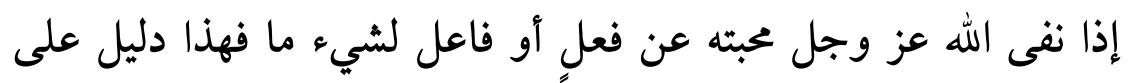

تحريمه (1)

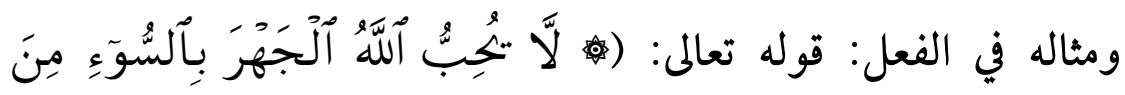

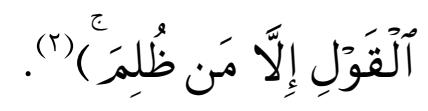

قرأ الجمهور بضم الظاء وكسر اللام، والمعنى: أن الله تعالى حرم آن يجهر أحد

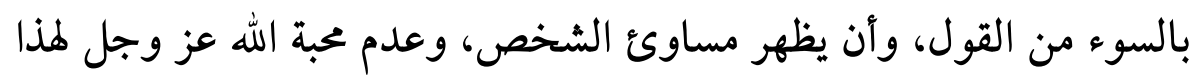

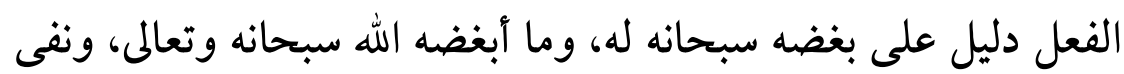
الإذن فيه فهو محرم (r).

وفي القراءات الشاذة، قرأ الحسن (إلَّاَ مَنَ ظُلمَمَ ) بفتح الظاء واللام مبنياً للفاعل، والمعنى على هذه القراءة: إلا من ظَلم في قول أو في فعل فاجهروا له

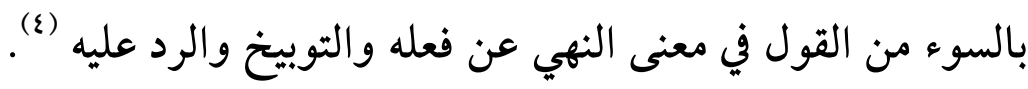

(1) (انظر: الإمام في بيان أدلة الأحكام(1/ / ـ (1)، وبدائع الفوائد (ع/ ه).

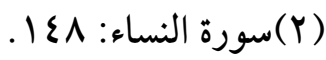

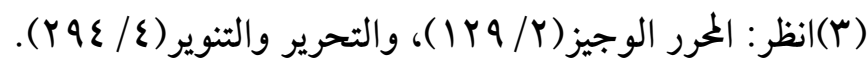

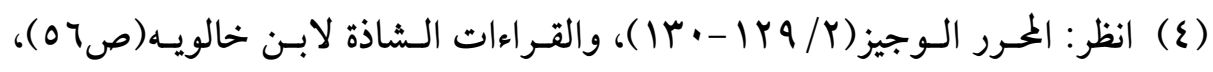

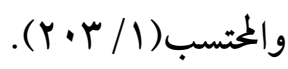


ومثال نفي محبة الله عز وجل للفاعل:قوله تعالى: (إِنَّهُ, لَا تشِيُبُ ألظَّلمِمِينَ (1) (1) ملت هذه الآية على نفي محبة الله سبحانه للظالمين المعتدين ونفي

$$
\text { الحبة دليل على عدم الإذن فيه (r). }
$$

إذا نفى الله الإيمان عن شخصٍٍ دل على التحريم، ومثاله: قوله

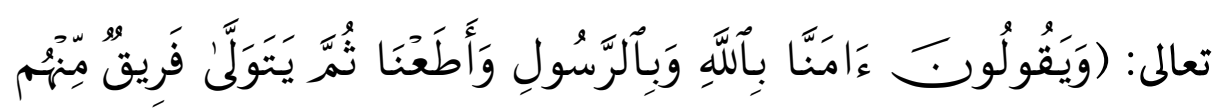

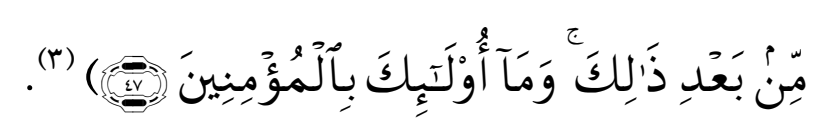

دلت هذه الآية على أن المعرضين عن حكم الله ورسوله ليسوا من

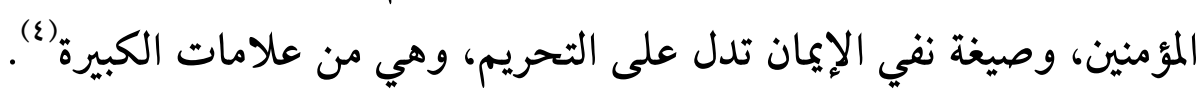

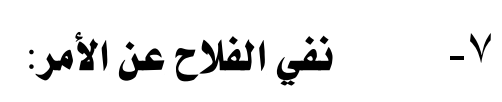

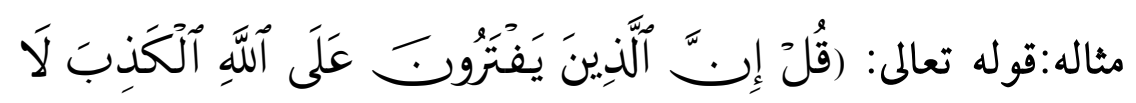

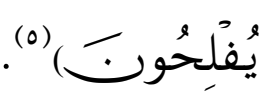

$$
\begin{aligned}
& \text { (1)سورة الشورى: •ع. }
\end{aligned}
$$

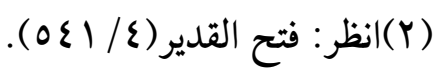

$$
\begin{aligned}
& \text { (צ) }
\end{aligned}
$$

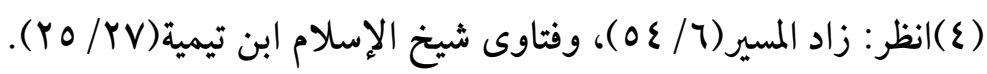

$$
\begin{aligned}
& \text { (0)سورة يونس: } 79 .
\end{aligned}
$$




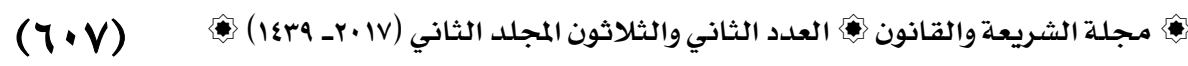

دلت هذه الصيغة - وهي نفي الفلاح- على الوعيد بأنهم لا يظفرون

ببغية، ولا يبقون في نعمة، والوعيد يعتبر من صيغ التحريم وأساليبه (')

$$
\text { م- النفي الذي بمعنى النهي: }
$$

اختلف الأصوليون في هذه الصيغة هل تفيد التحريم أم لا؟ وهل هي الهي

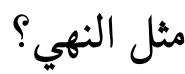

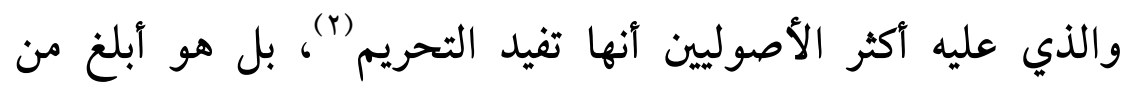

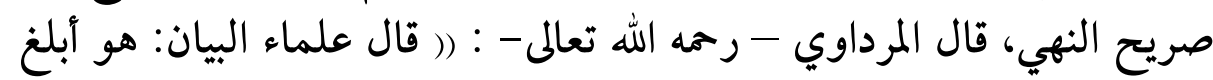

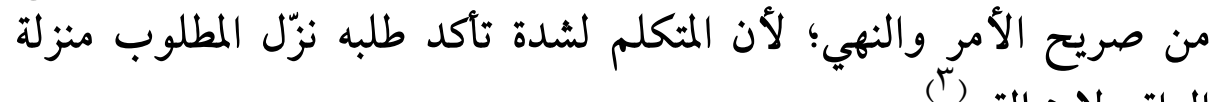

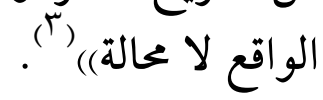

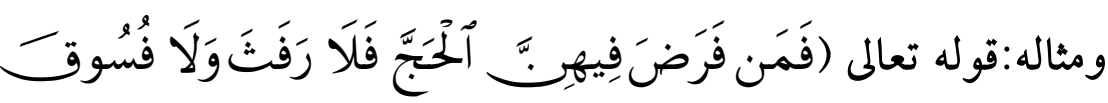

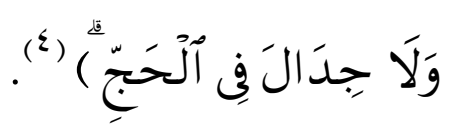

قال ابن قدامة - رحمه الله تعالى- (( وهذا صيغته النفي أريد به النهي، كقوله

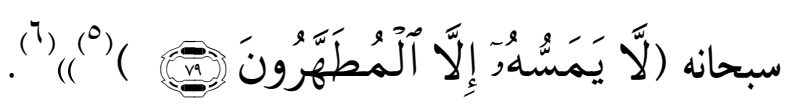

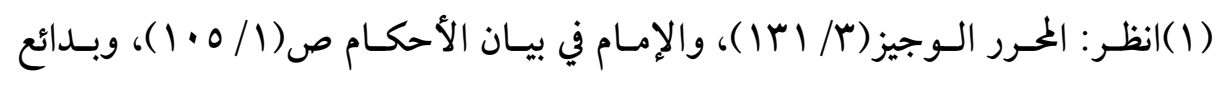

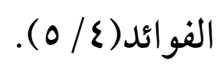

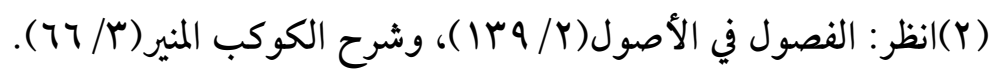

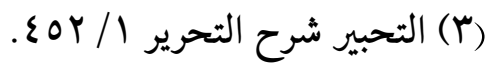

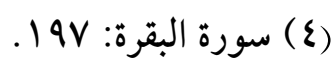

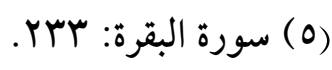

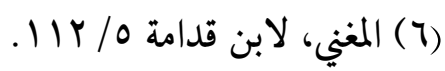


$(7 \cdot 1)$

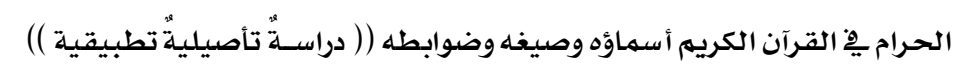

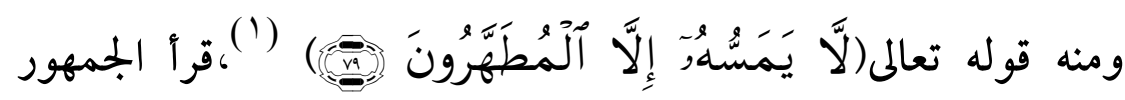

(ألَُّطَهَرُونَ) بفتح الطاء والهاء المشددة، وقرأ نافع وأبو عمرو وبخلاف

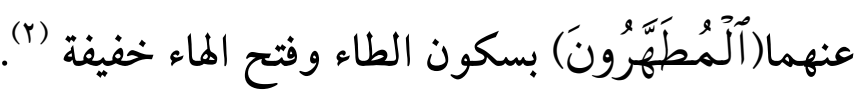
قيل: الضمير في يمسه يعود إلى الكتاب المكنون، ومن قال بأنها مصاحف

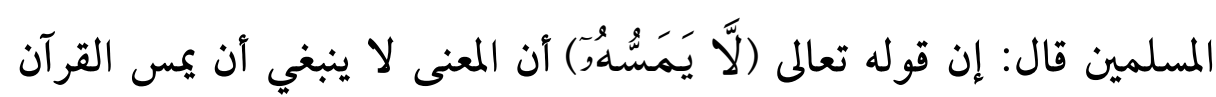
إلا من هو على طهارة من الناس، فالنفي هنا متضمن التحريم، فهو بمعنى النهي (r) (ب) ومن أمثلته أيضاً قوله تعالى: (لَا تَعَبُدُونَ إِلَّا آللَّه)(ఓ) قال ابن جزي الكلبي- رحمه الله - في تفسير هذه الآية: (ر وقيل: خبرّ بمعنى النهي؛ ويرجحه

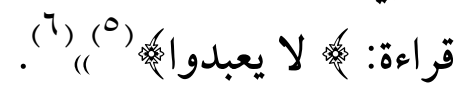

(1) (1) سورة الواقعة: V9.

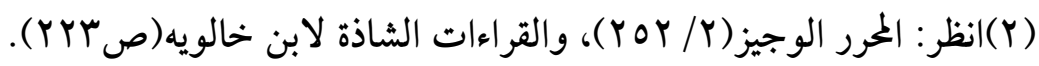

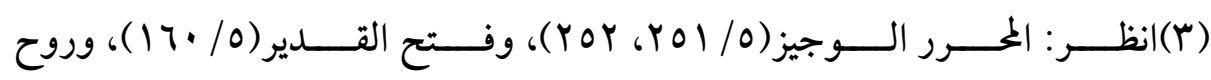

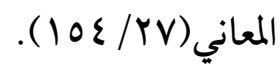

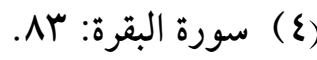
(0) وهي قراءةٌ شاذة منسوبةٌ لأبي بن كعبـ- رضـي الله عنه - انظـر : معـاني القـرآن

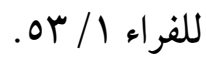

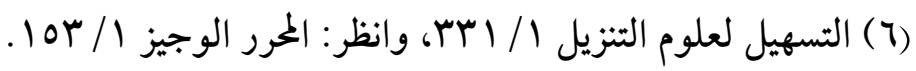




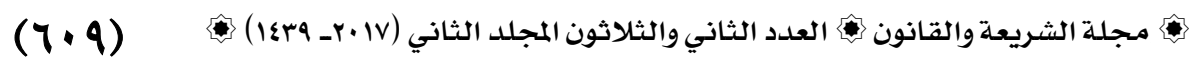

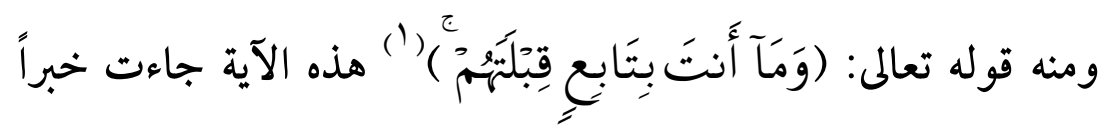

بمعنى النهي فأفادت التحريم. قال ابن الفرس - رحمه الله - في تفسير هذه

الآية: (ر خبراً بمعنى النهي، فيكون معناه: ولا تتبع قبلتهم، أي لا تُصلٍ إليها،

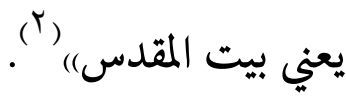

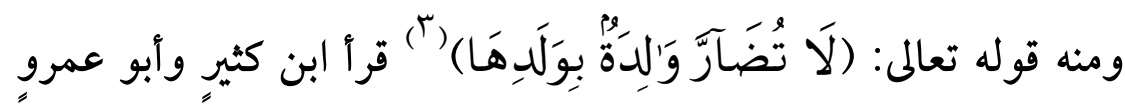

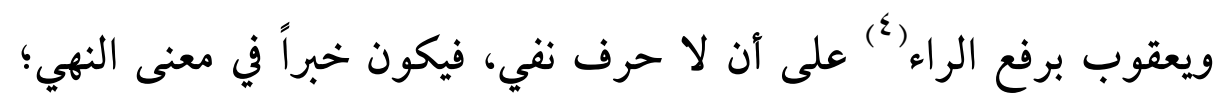

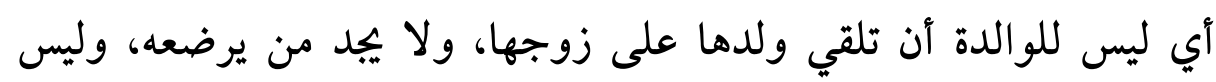
للزوج أن ينتزع منها ولدها وهي ترغب في ان ولني أن ترضعه.

قال ابن عاشور - رحمه الله تعالى-: (( وقرأ ابن كثيرٍ وأبو عمروٍ برفع

الراء على أن (( لا) حرف نفي، والكلام خبرّ في معنى النهي..) (0).

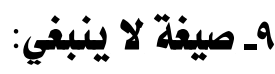

قال ابن عطية - رحمه الله تعالى-: ( وهذه العبارة ما كان، وما ينبغي ونحوها تجيء لحظر الشيء)(").

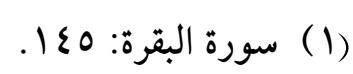

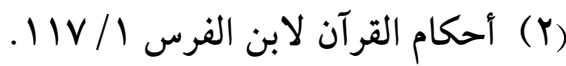

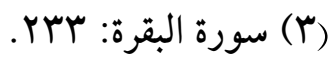

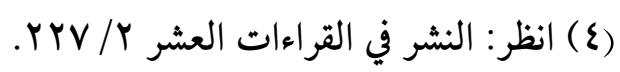

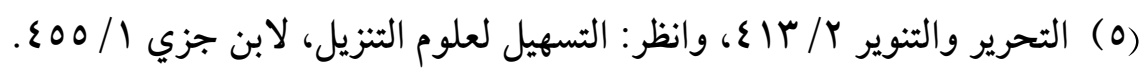

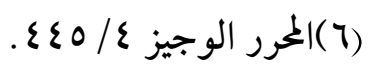


(7) الحرامهِ القرآن الكريم أسماؤه وصيغه وضوابطه (( دراسـةُّ تأصيليةّة تطبيقية ))

قال ابن القيم - رحمه الله تعالى- : (( وقوله (ا لا ينبغي)؛ فإنها في لغة القرآن

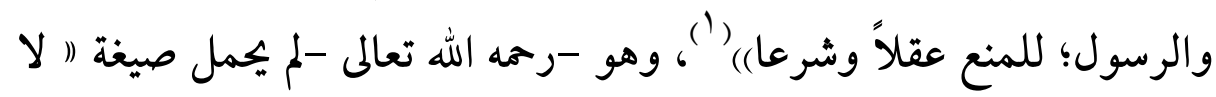
ينبغي " على مصطلح المتأخرين الأصوليين.

وقال ابن بدران - رحمه الله تعالى -: (ر قد اطرد في كلام الله ورسوله

(لا ينبغي" في المخظور شرعا وقدرا، وفي المستحيل الممتنع.. )) (r).

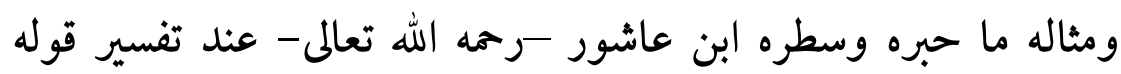

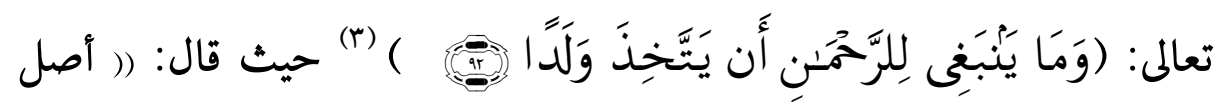

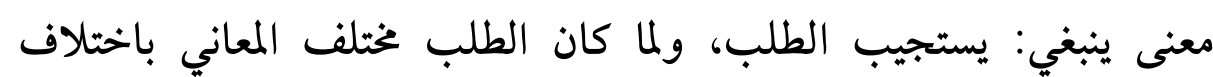

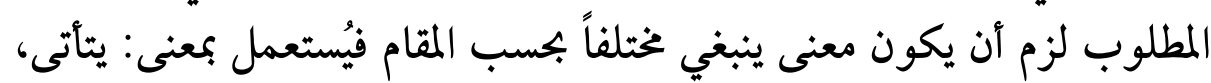

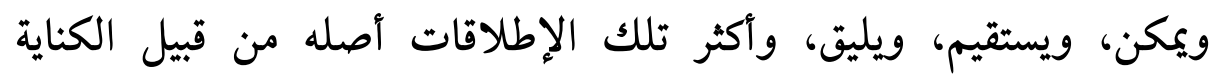

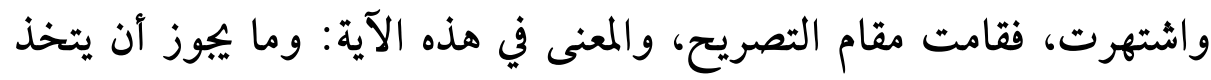

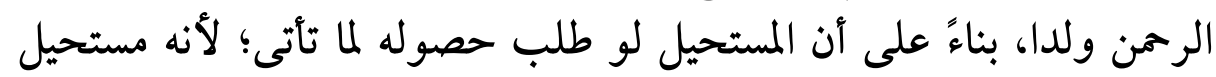

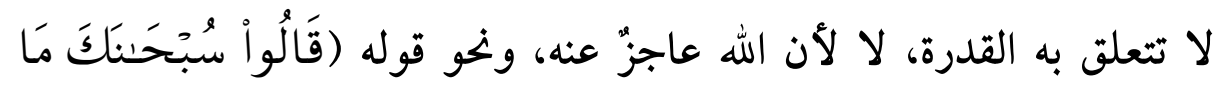

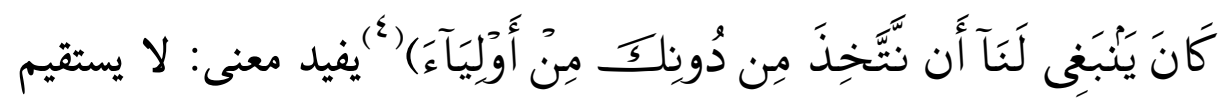

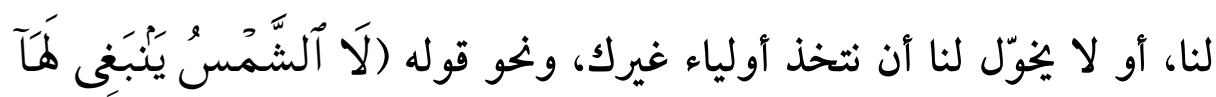

$$
\begin{aligned}
& \text { (1)بدائع الفوائد ( ع / 0). }
\end{aligned}
$$

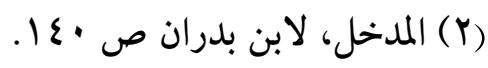

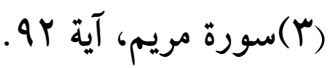

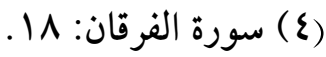




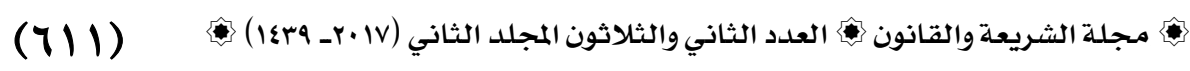

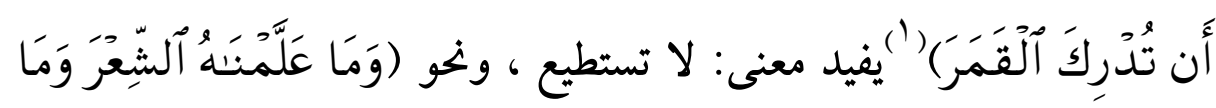

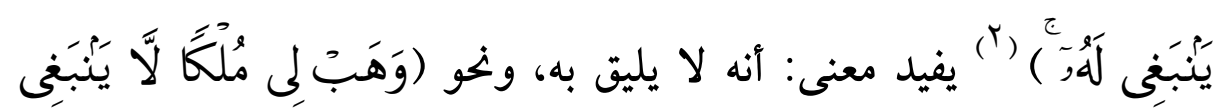

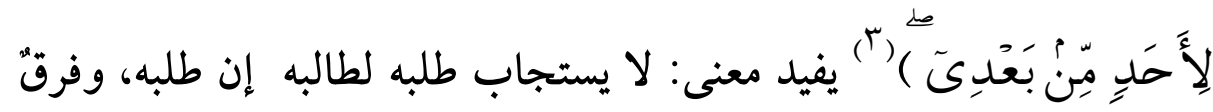

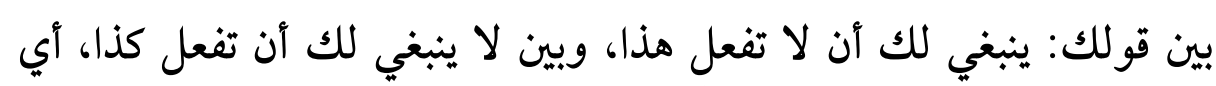

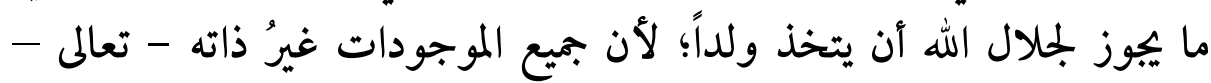

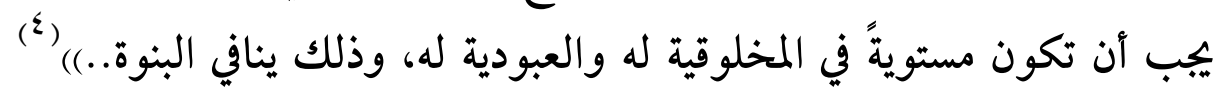

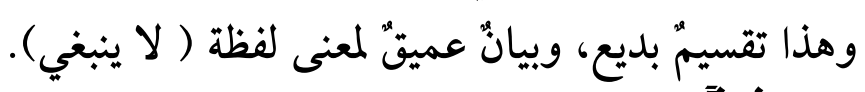

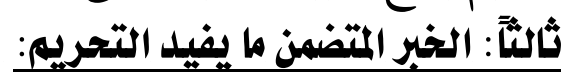
قد تكون الصيغة خبرية لكنها تدل على طلب الترك وتفيد التحريم

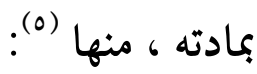

\section{الصيفة الخبرية التضضمنة مادة حرّم وما تصرف منها (؟):}

$-1$

فإذا استُعمل لفظ التحريم ومشتقاته في القرآن الكريم دلّ على أن هذا

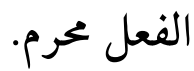

$$
\begin{aligned}
& \text { (1) (1) سورة يس: • ع. (1) (1) }
\end{aligned}
$$

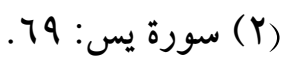

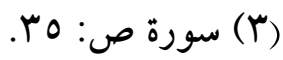

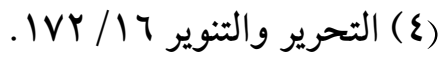

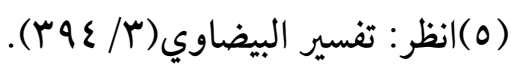

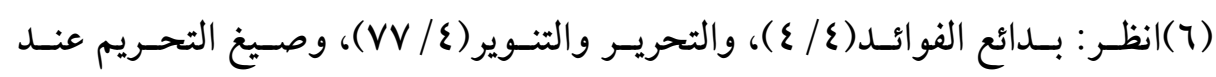

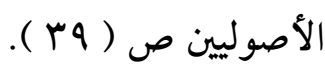


$(T \mid Y)$

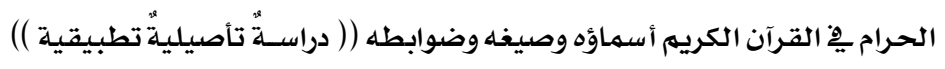

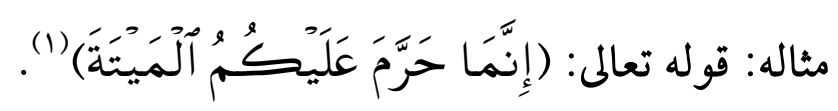

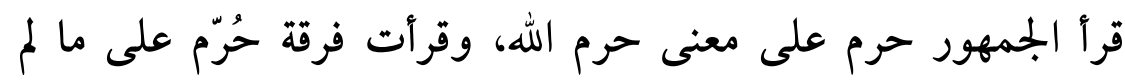

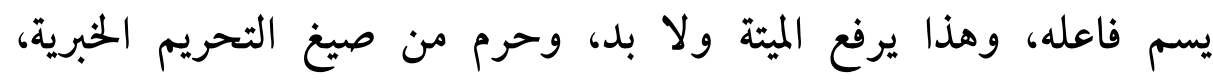

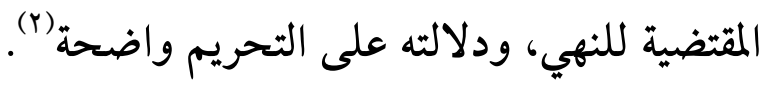

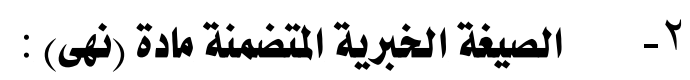

وهي صريحة في النهي وحكم النهي صيرورة الفعل المنهي عنه

فلفظ النهي يفيد عموم الترك.

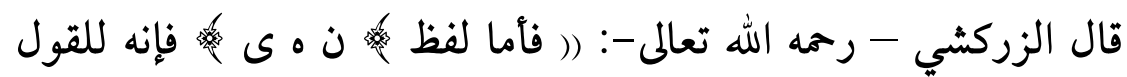

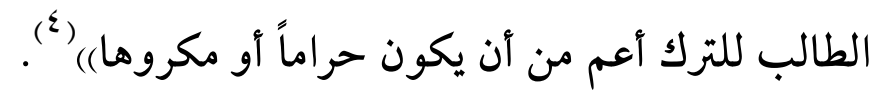

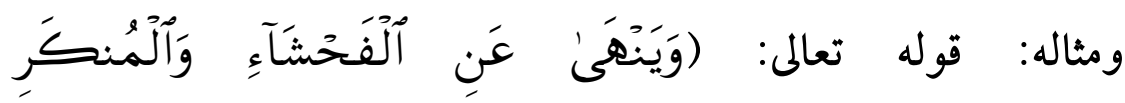

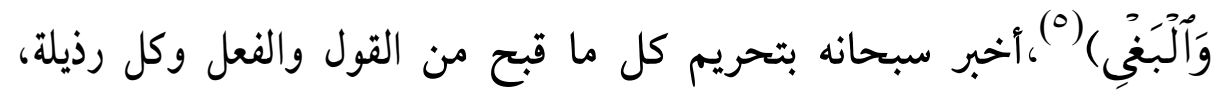
وذلك بصيغة الخبر الدالة على الترك، المتضمنة للتحريم وهي (نهى) (1).

$$
\begin{aligned}
& \text { (1) سورة النحل: } 110 .
\end{aligned}
$$

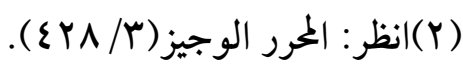

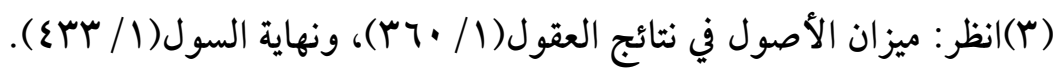

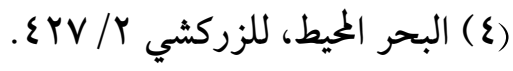

$$
\begin{aligned}
& \text { (1)سورة النحل: •9. } 9 .
\end{aligned}
$$

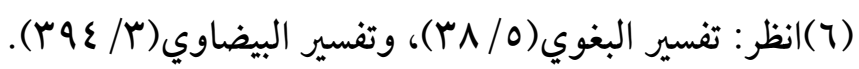




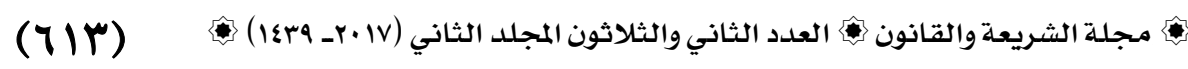

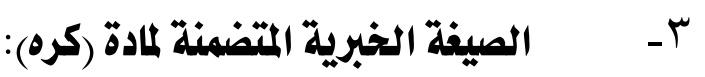

وقد تقدم التطبيق في أسماء الحرام. (1)

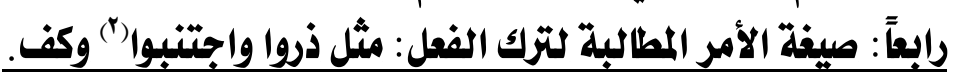

إذا وردت صيغة أمرٍ تدل على طلب الترك مثل (وَذَرَواً) أو (اجتنبوا)

تدل على التحريم. - تلم

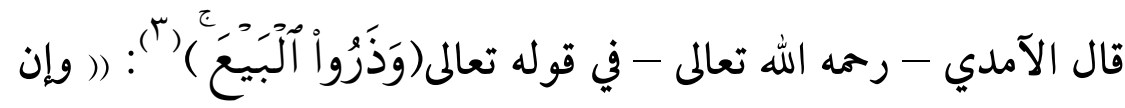

كانت صيغته صيغة أمرٍ إلا أنه في معنى النهي؛ إذ النهي ترك الفعل، وقوله

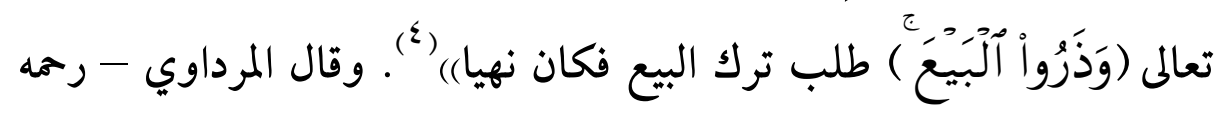
الله تعالى - : ((اترك،وكف) أَمْرَان وهما اقْتِضَاء فعلهُ وكفف،( ولا تترك ولا

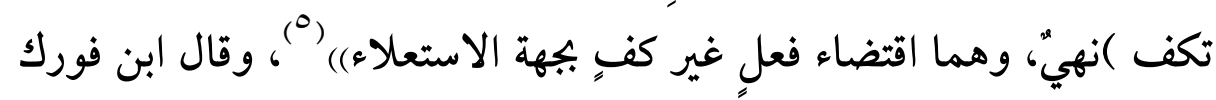
- رممه الله -: صيغته-أي:النهي- عندنا ( لا تفعل) و (" انته ") و و

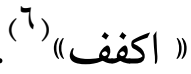

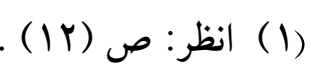

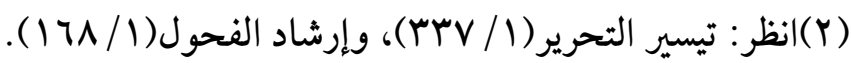

(ب) (ب) سورة الجمعة: 9 (ب)

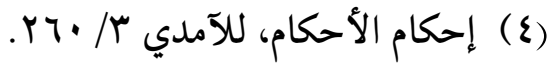

(0) التحبير شرح التحرير 0 / (1) (1)

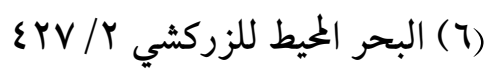


(7)乏)

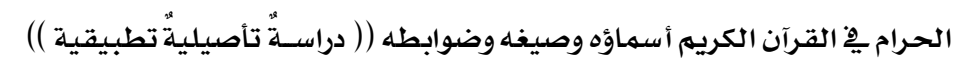

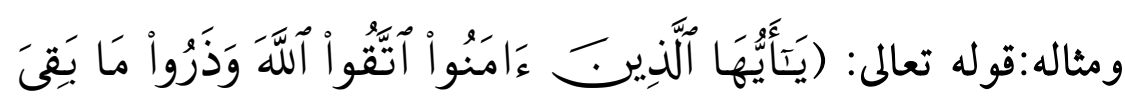
مِنَ آلرِبَّوَأ(')"، دلت هذه الصيغة على تحريم الربا، وإن وردت بأسلوب الأمر إلا أنها صيغة نهي بالمعنى (؟َ) وهي تفيد التحريم.

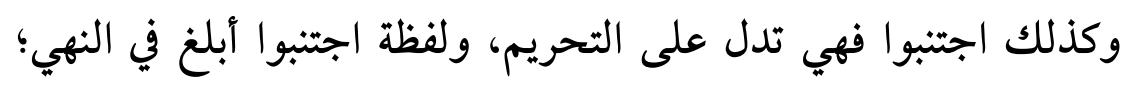

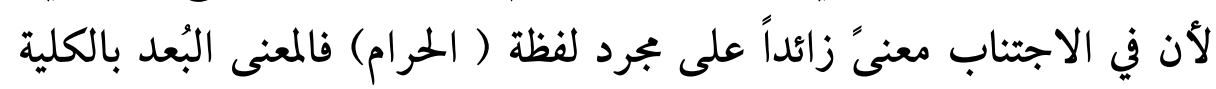

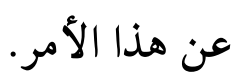

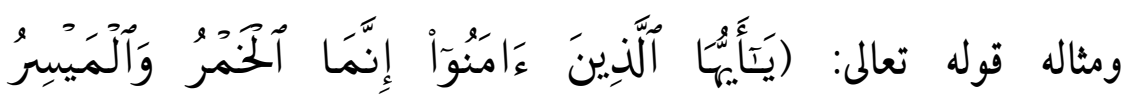

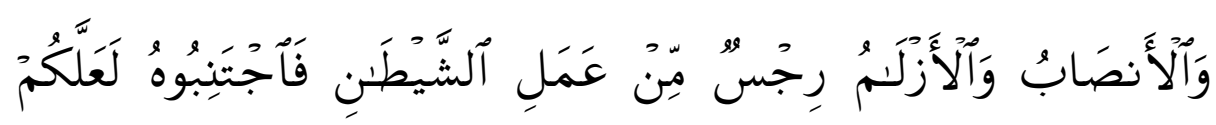

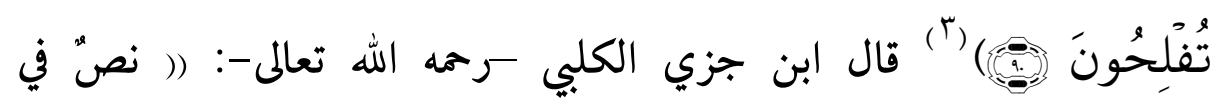
التحريم، والضمير يعود على الرجس الذي هو خبر عن جميع الأشياء

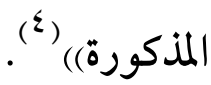

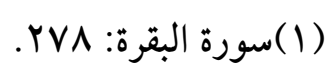

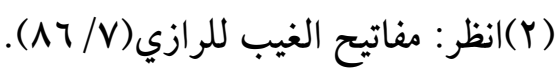

$$
\begin{aligned}
& \text { (Y) سورة المائدة: •9. } 9 .
\end{aligned}
$$

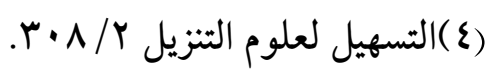


(7)0)

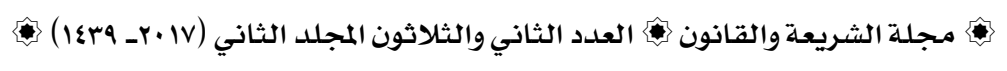

وكذلك لفظة ( كفّوا ) فإنها تفيد التحريم، ومثاله في قوله تعالى: (أَلَّر

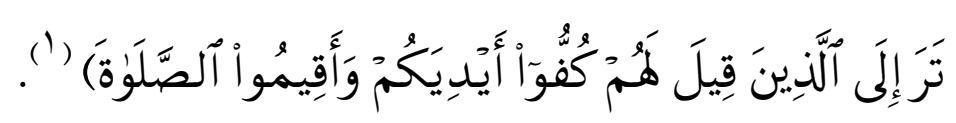

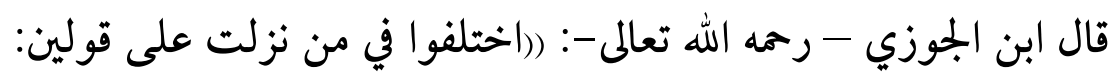

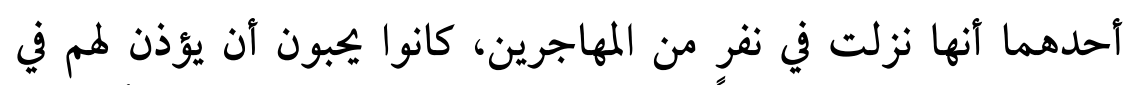

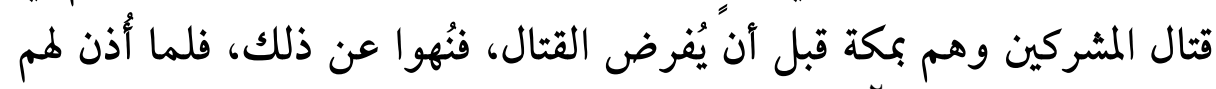

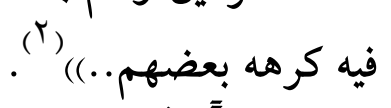
خامساً: ذكر الفعل مقروثاً بعقوبة مترتبة عليه: دنيوية أو أخروية أو وصف يدل على التحريم(").

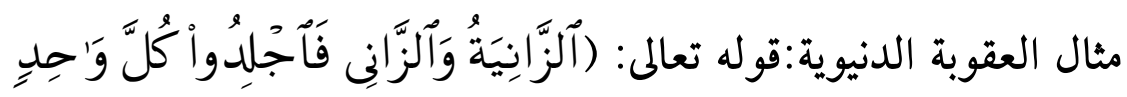

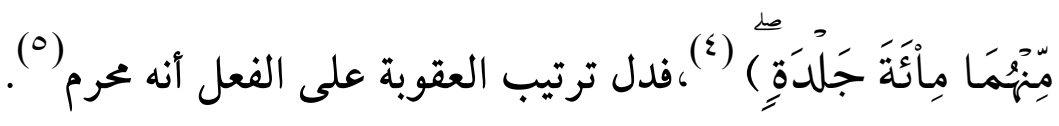

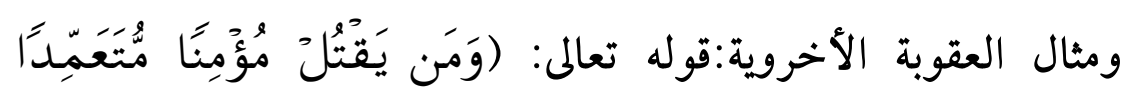

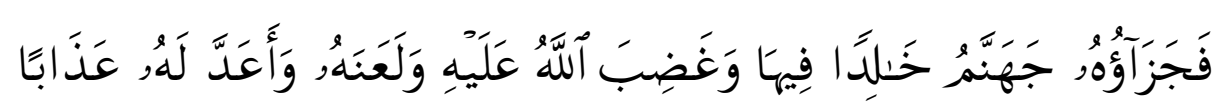

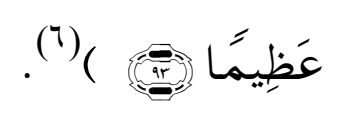

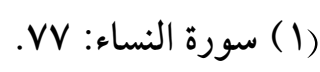

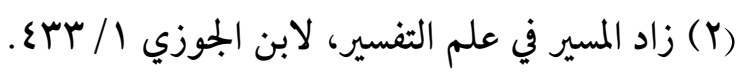

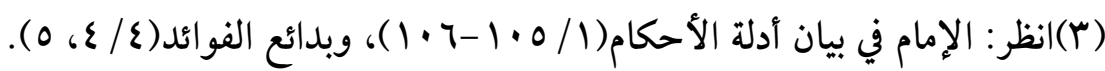

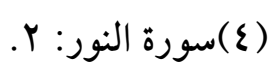

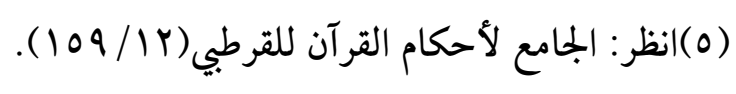

(7)سورة النساء: باء. 
(7)

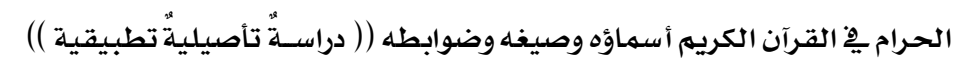

هذه الصيغة رتبت العقوبة على فعل القتل العمد للمؤمن، فدلت على التحريم

الشديد لذلك (1)

ومثال الفعل المقترن بوصف يدل على التحريم:قوله تعالى: (وَمَنْ لُّمد

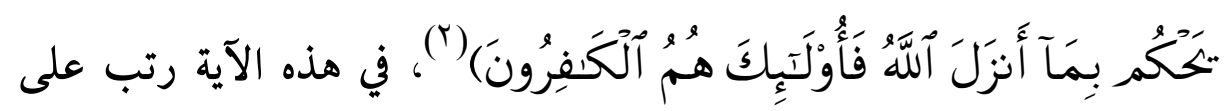

الفعل وصف وهو الكفر، فدل على تحريم الحكم بغير ما أنزل الله (").

\section{ساداً: الاستثناء من الإباحة:}

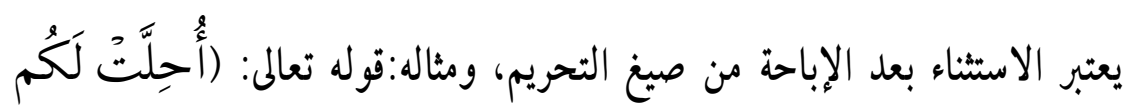

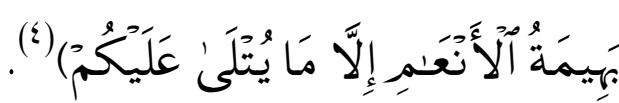

فيلحظ أن الأشياء المذكورة في الآية التالية حرمت هنا بأسلوب

الاستثناء من الإباحة، وهو يدل على التحريم (ْ).

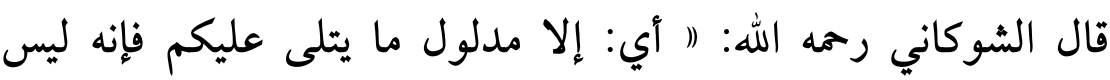

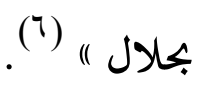

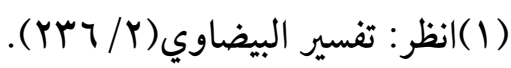

(Y) (Y)

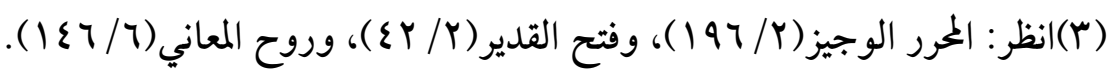

(ع) سورة المائدة: 1.

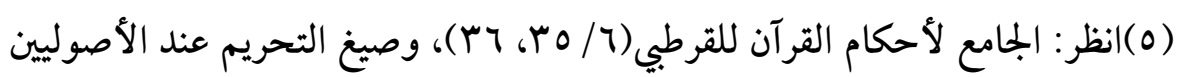

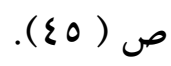

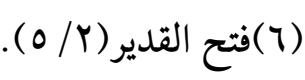




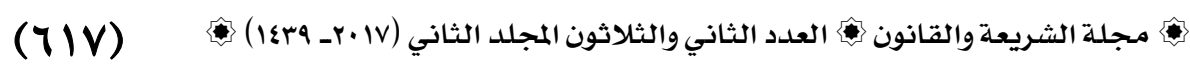

الختلفاً:صيغ الأصرام الضمنية: القول الأول: أن الأمر بالشيء هو عين النهي عن ضده. وهذا القول مبنيّ على إثبات الكلام النفسي؛ إذ الأمر عندهم لا صيغة له، وإنما هو معنى قائم بالنفس، فالأمر هو نفس النهي عندهم، وهو قول الأشاعرة' ')

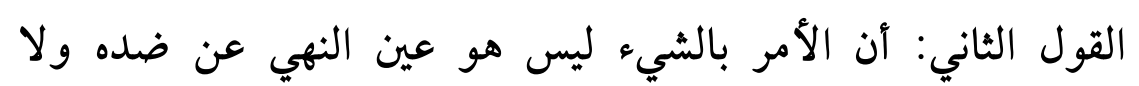

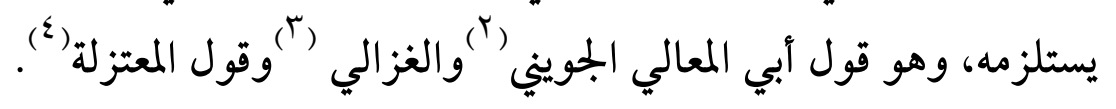
القول الثالث: أن الأمر بالشيء ليس هو عين النهي عن ضدهاهي ولكنه يستلزمه ويتضمنه من طريق المعنى. قال ابن السمعاني: هو مذهب عامة

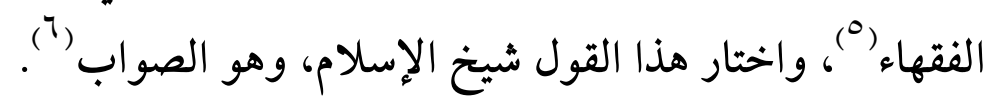

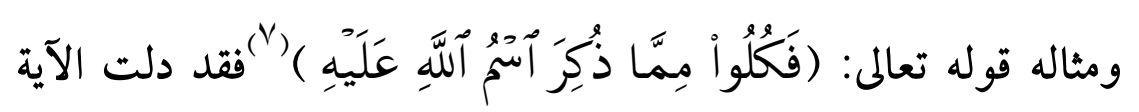
على النهي بما يقتضيه مفهوم المخالفة.

$$
\begin{aligned}
& \text { (1) انظر: نفائس الأصول \& / • هـ 1. } \\
& \text { Vr-VY/l البرهان }
\end{aligned}
$$

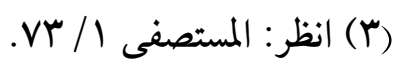

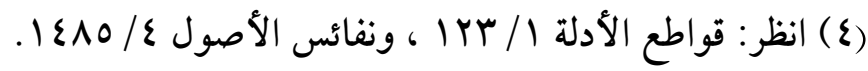

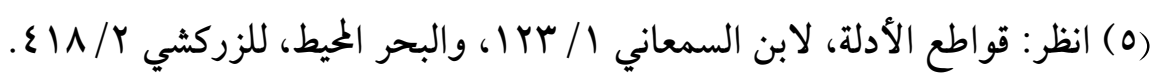

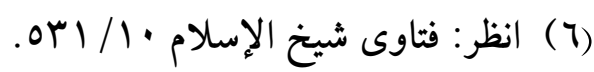
(V) 
(7)A)

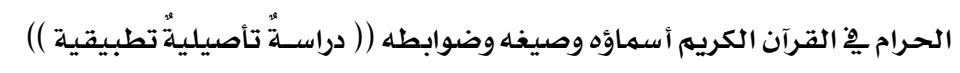

قال ابن جزي - رحمه الله تعالى -: ( وهذا النهي يقتضيه دليل الخطاب

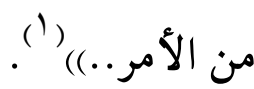

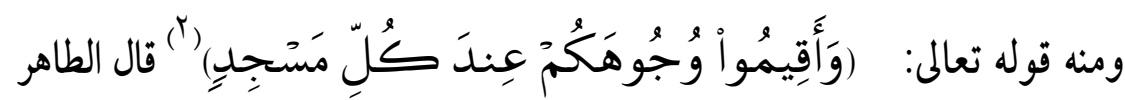

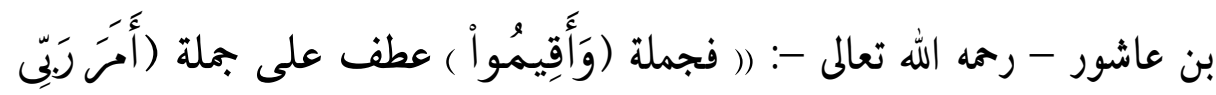
بِآلِقِستطِ ) أي: قل لأولئك المخاطبين أقيموا وجوهكم. والقصد الأول منه إبطال بعضٍ مما زعموا أن الله أمرهم به بطريق أمرهم بضد ما زعموه ليحصل

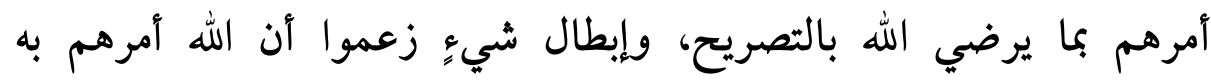

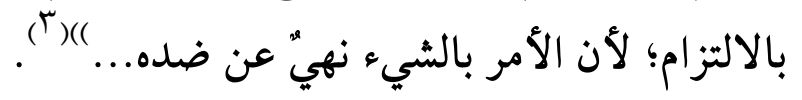

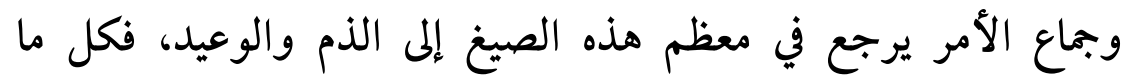

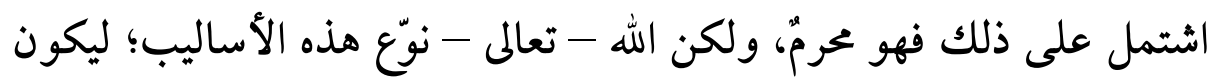

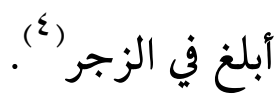

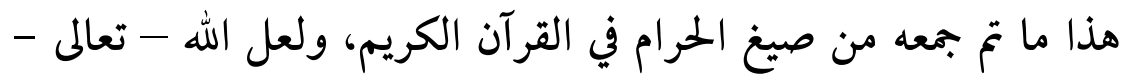
يقيض لها من يكمل صيغ الحرام والتطبيق عليها في القرآن المجيد.

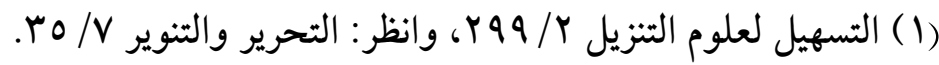

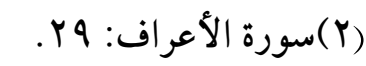

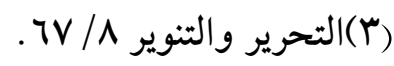

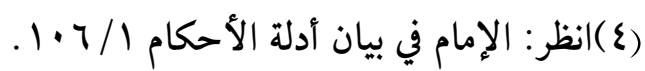




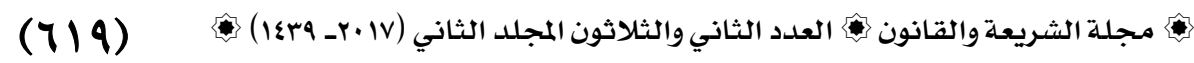

ومما يجدر التنبيه إليه أن معظم صيغ الحرام قد جمهالعز بن عبد السلام-

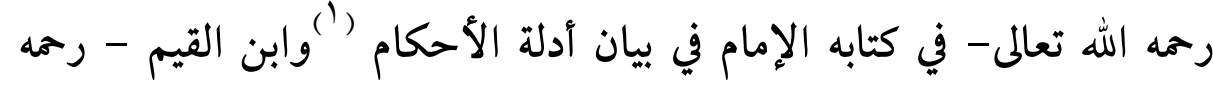

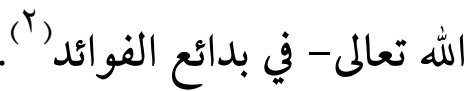

\section{触绻}

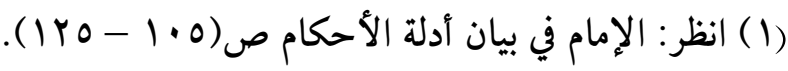

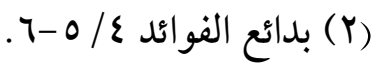


(7r.) الحرام فِ القرآن الكريم أسماؤه وصيغه وضوابطه (( دراسـة تأصيليةٌ تطبيقية ))

\section{المبحث الرابع: ضوابط وقواعد الحرام في القرآن الكريه.}

إن مما يميز المصطلحات القرآنية الدقة والضبط، بجيث تحوي جميع

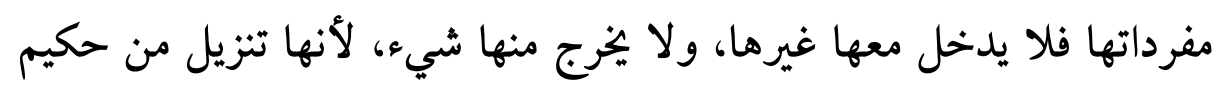

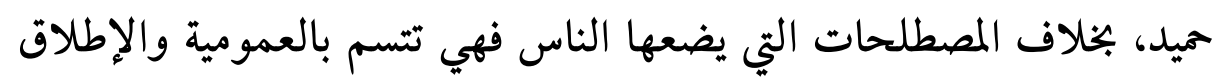
وعدم الضبط، وتخلط بين الصواب والخطاً.

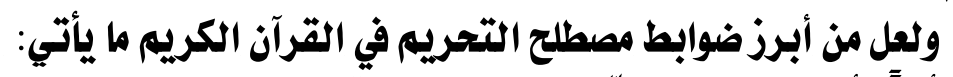

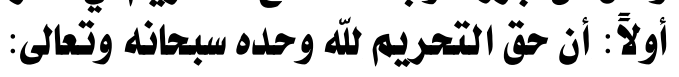

فليس لأحد من البشر منازعته عز وجل في ذلك قال تعالى: (قُلْ

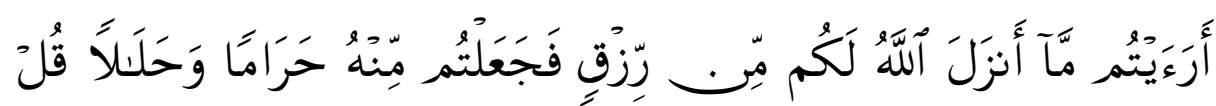

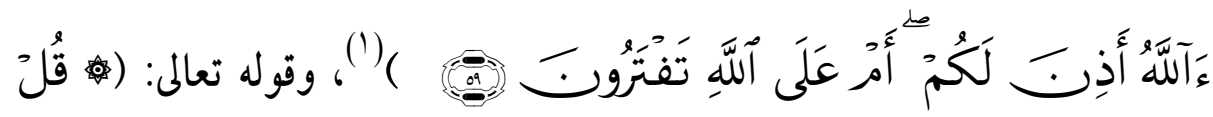

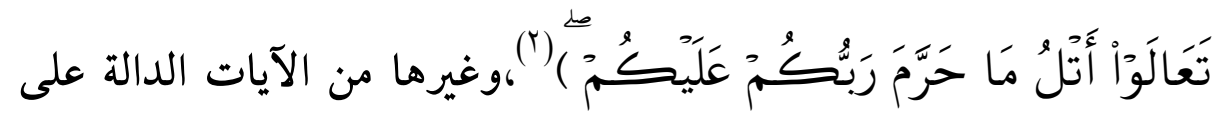
أن حق التحريم خاص بالرب سبحانه وتعالى.

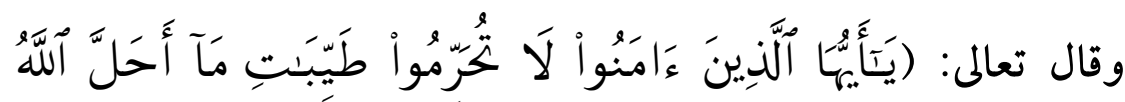
(r) (لَ)

$$
\text { سورة يونس: سورة الأنعام: } 101 .
$$




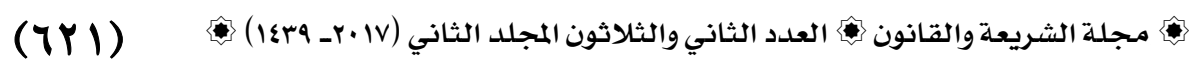

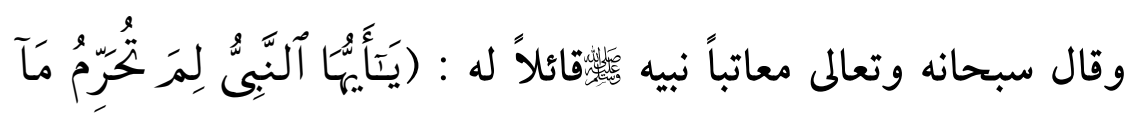

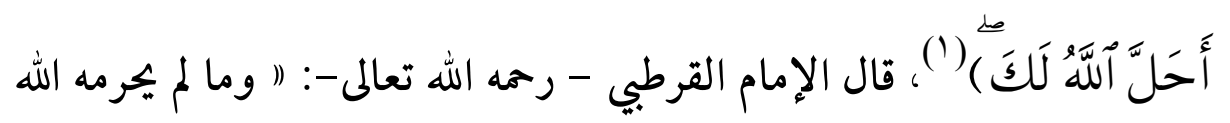

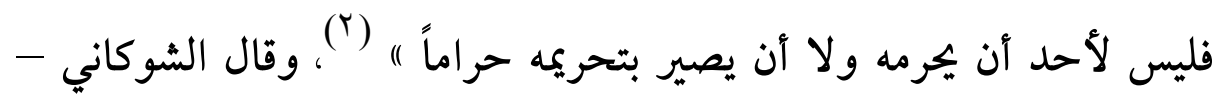
رحمه الله : ( التحليل والتحريم هو إلى الله سبحانه لا إلى غيره، ومعاتبة نبيه

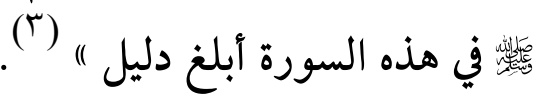

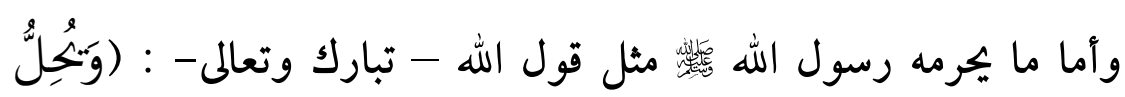

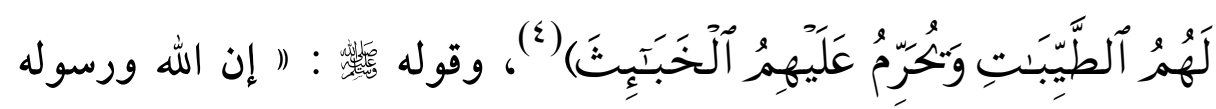
حرم بيع الخمر والميتة والخنزير " (0).

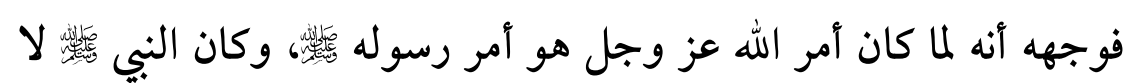

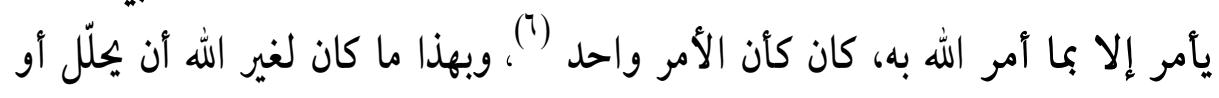
يجرم على العباد ما لم يأذن به الله.

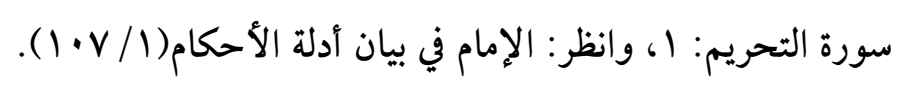

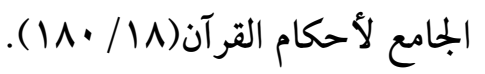

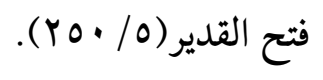

$$
\begin{aligned}
& \text { سورة الأعراف: } 10 \mathrm{~V}
\end{aligned}
$$

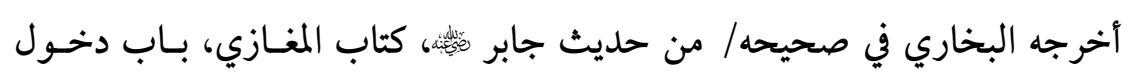

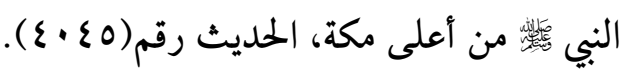

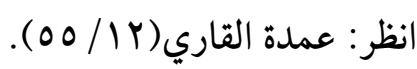


(TYY)

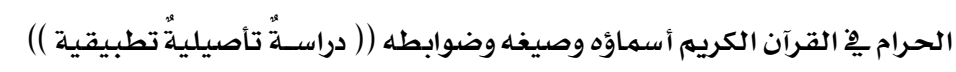

\section{ثانياً: أن من حلل أو حرم دون اللّه فقد شرّع:}

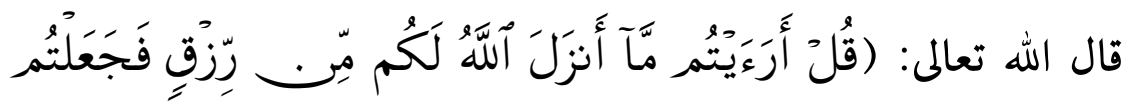

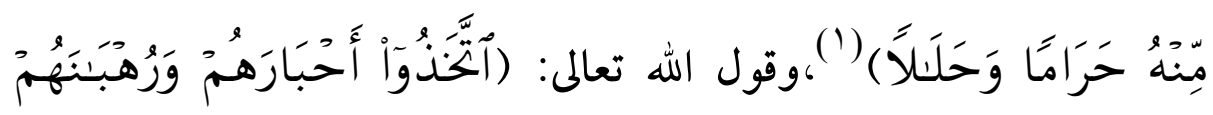

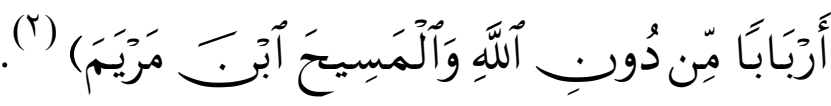

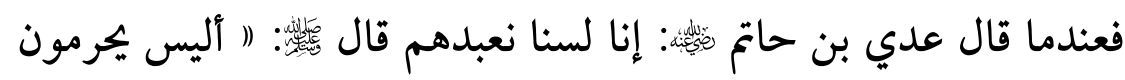

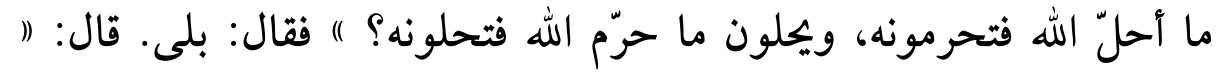
فتلك عبادتهم " ("). قال محمد رشيد رضا -رحمه الله- عند قوله تعالى: (وَحَرَّمُواْ مَا

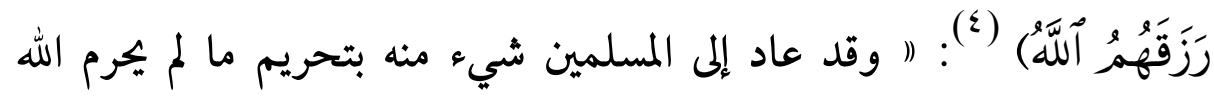
وجعله ديناً وهم لا يشعرون ") (0).

$$
\text { سورة يونس: } 49 .
$$

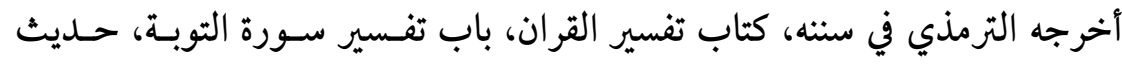

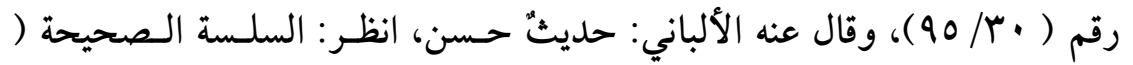




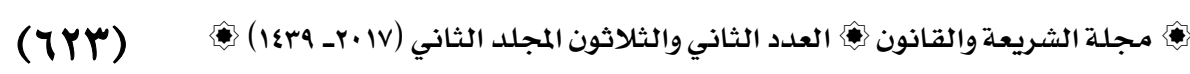

وقال- رحم الله- : ( ذلك أصل الدين الأعظم توحيد الله تعالى باعتقاد

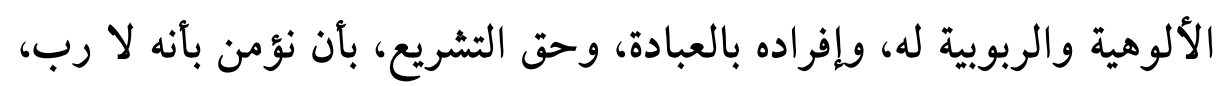

ولا خالق غيره، ولا إله يعبد معه أو من دونه، ولا شارع سواه لعبادةٍ ولا

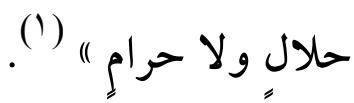

ثالثًاً: أن الحرام في القرآن الكريم بيّنْ واضح:

فلا لبس فيه ولا غموض، وهذا يدل على دقة مصطلح الحرام في كتاب

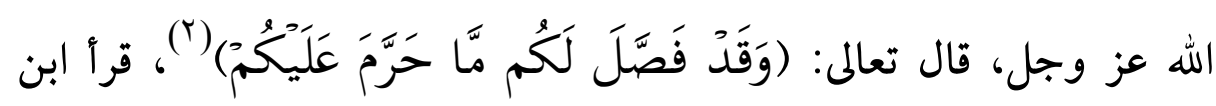

كثير وأبو عمرو وابن عامر (وَقَقَّ فَصَّلَ لَكُم مَّا حَرَّمَ عَلَيْكُمْ) بضم الفاء

وكسر الصاد (فُصِّل) وبضم الحاء وكسر الراء (حُرمِ) على البناء على ما لمج

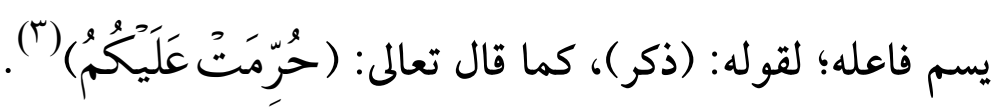

وقرأ نافع ويعقوب وحفص: (وَقَدْ فَصَّلَ لَكَمُ مَّا حَرَّمَ عَلَِكمُمْم) على

البناء للفاعل، والمعنى فصل الله - تعالى - ما حرمه عليكم، لقوله: (ا اسم الله )؛؛ لتقدم

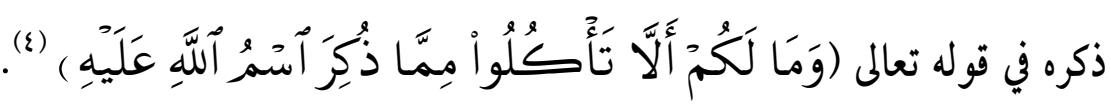

$$
\begin{aligned}
& \text { (1) المصدر السابق (1/ (1) ). } \\
& \text { (Y) سورة الأنعام: } 119 . \\
& \text { (ץ) سورة المائدة: } \\
& \text { (ع) ( ) سورة الأنعام: } 119 .
\end{aligned}
$$


(TY\&) الحرام هِّ القرآن الكريم أسماؤه وصيغه وضوابطه (( دراسـة تأصيليةّ تطبيقية ))

وقرأ أبو بكر عن عاصم وحمزة والكسائي " وقد فَصَّل " بالفتح و

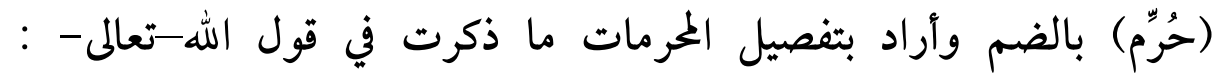

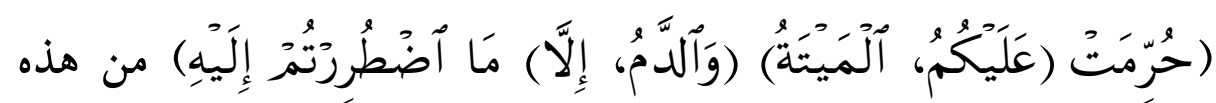

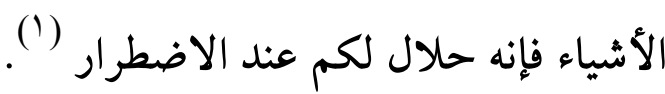
وهذه الآية تدل على أن الله سبحانه قد بين لنا الحرام من الحلال، وأزال كل لبس، وشك، وهذا هو منتهى الدقة والوضوح (؟).

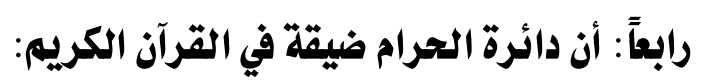

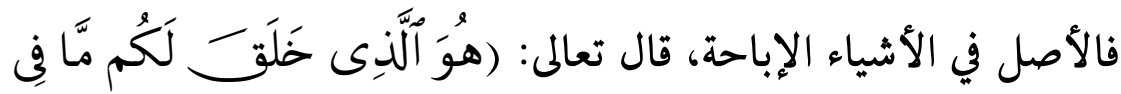

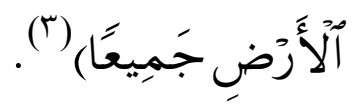
ومما يدل على أن دائرة الحرام ضيقة في كتابه سبحانه وتعالى أسلوب الحصر،

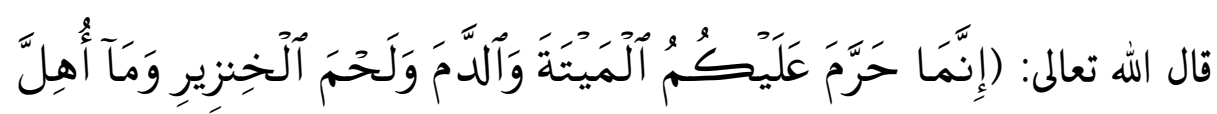

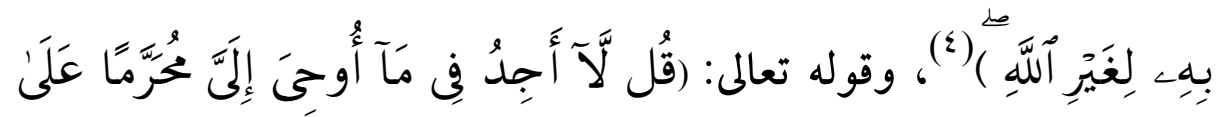

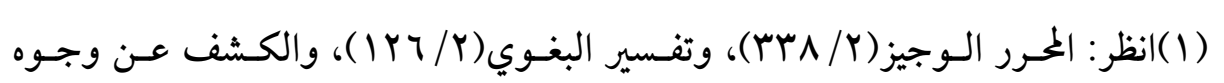

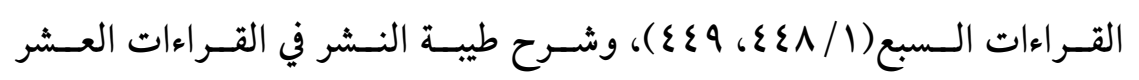

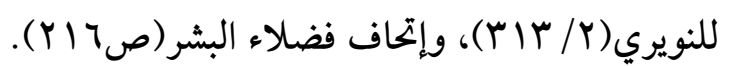

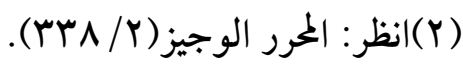

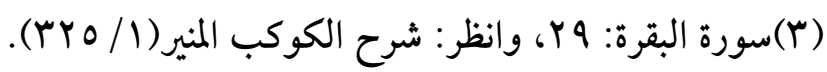

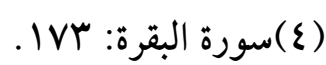




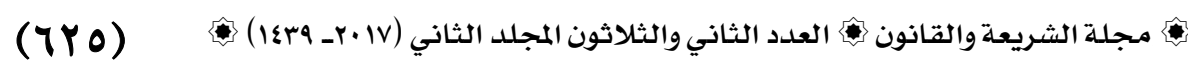

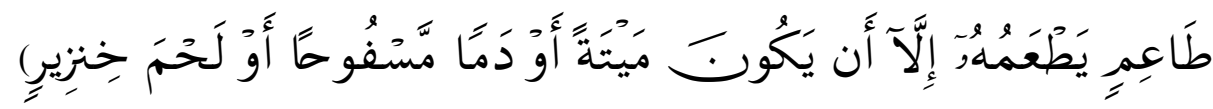
الآية (')، فالحصر هنا يدل على قلة الحرام (؟). ومنهنا يدرك خطأ ما يفعله بعض الغيورين من الناس حيث يميلون إلى

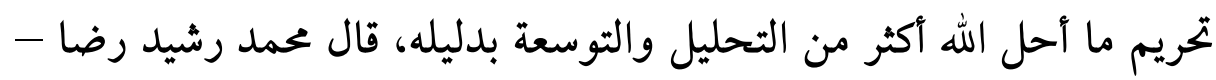

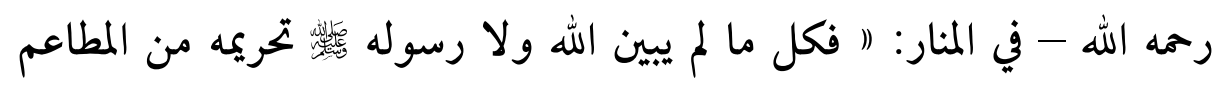

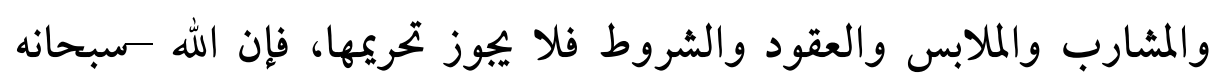

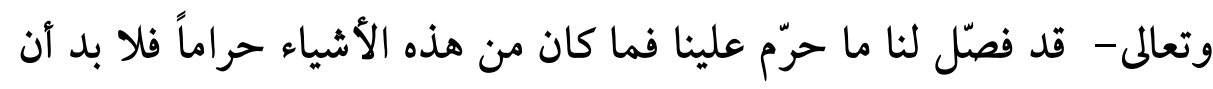

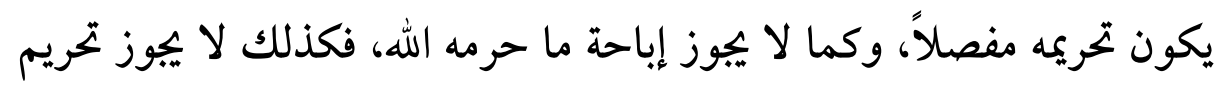

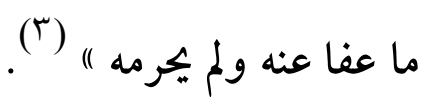

\section{خامساً: أن من حرّم أو حِّل من دون اللّه وصفه اللّه سبحانه بأسوأ الأوصاف منها:}

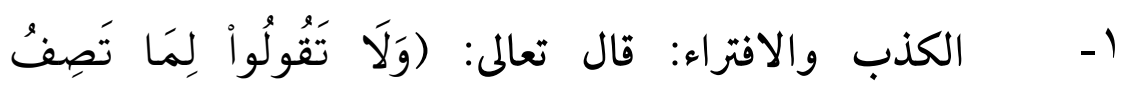

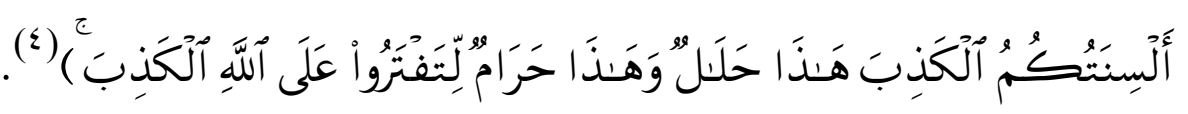

$$
\begin{aligned}
& \text { (1) سورة الأنعام: (1) } 0 \text { (1) }
\end{aligned}
$$

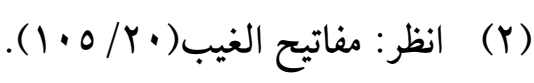

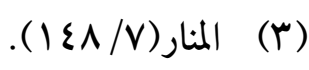

$$
\begin{aligned}
& \text { سورة النحل: } 117 .
\end{aligned}
$$


(TYY)

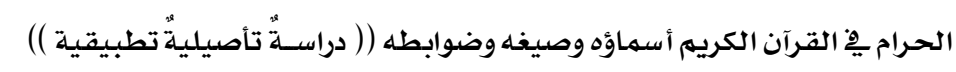

قرأ الجممهور (آلْكَذِبَّ) بفتح الكاف وكسر الذال وفتح الباء مفعول

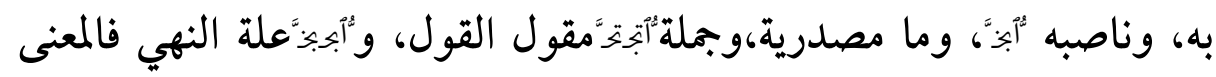
لو صف ألسنتكم من الكذب. وقرئ (الكذب) بضم الكاف والذال والباء نعتاً للألسنة.

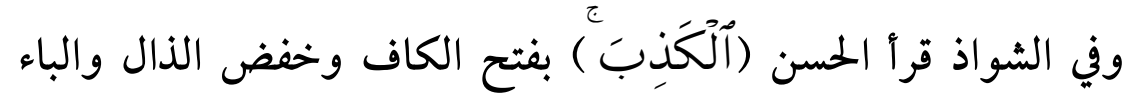

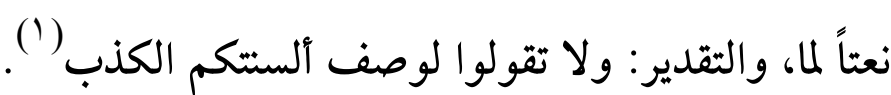

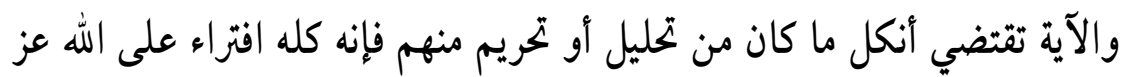

ז- الإنكار الشديد والوعيد لمن حرم أو حلل من دون الله.

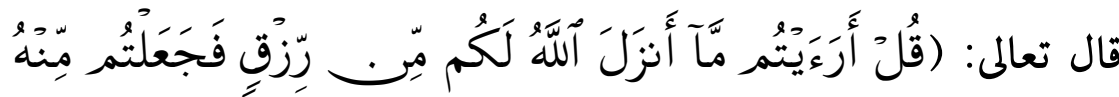

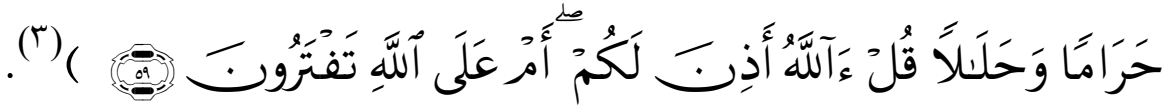
أنكر الله تعالى ووبخ المشركين الذين ابتدعوا تحريم ما أحل الله، وتحليل

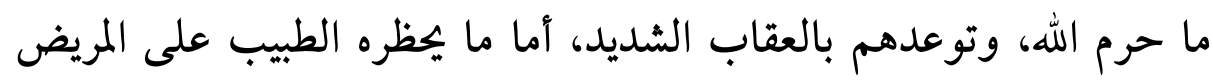

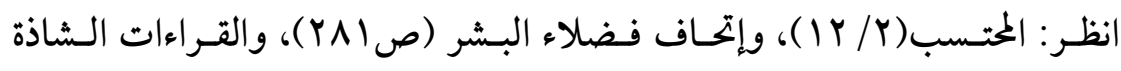

$$
\text { كلقاضي(·) (1). }
$$

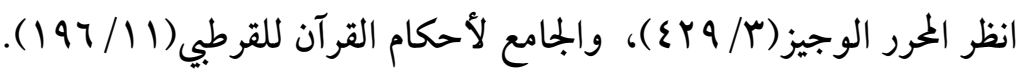




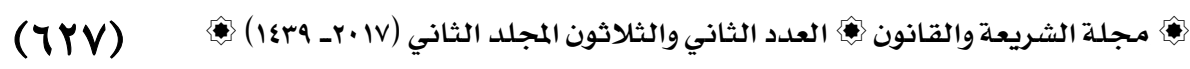

من طعام حلال في نفسه، أو ما يمنع الحاكم العادل الناس من التصرف فيه من

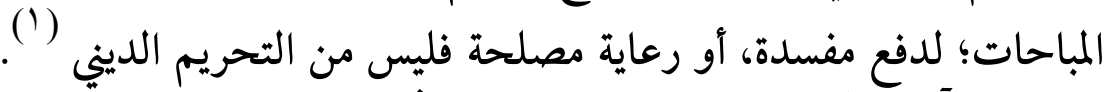

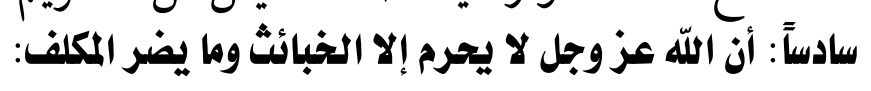

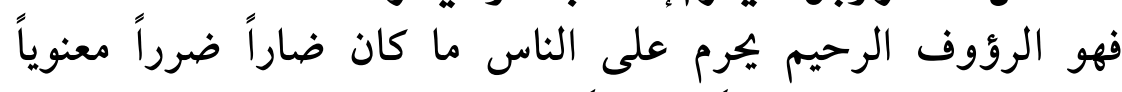

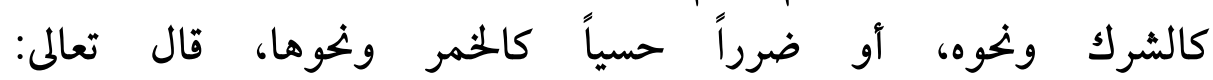

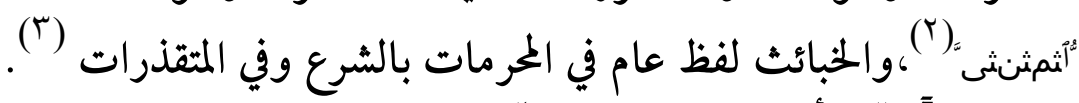

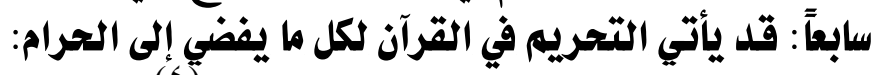

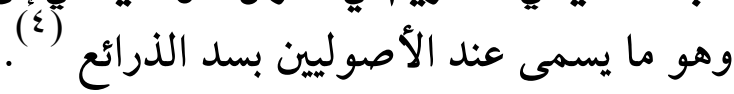

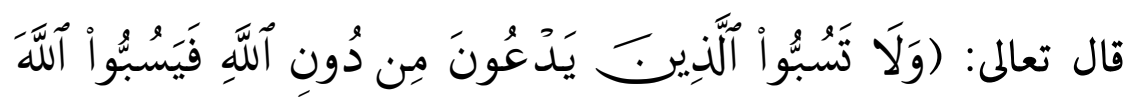

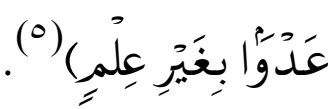

$$
\begin{aligned}
& \text { قرأ يعقوب (عُدُوّا) بضم العين والدال وتشديد الواو. }
\end{aligned}
$$

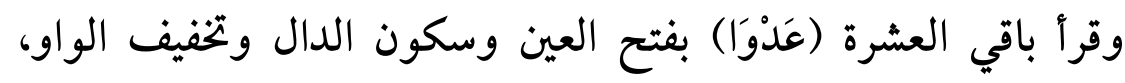

وهما لغتان بمعنى واحد وهو الظلم والجور.

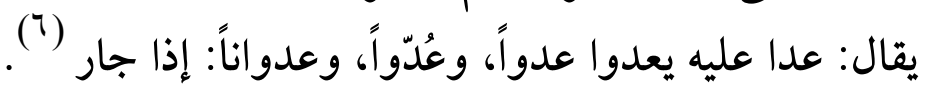

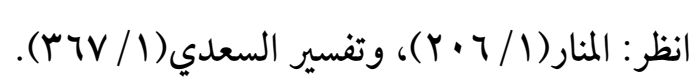

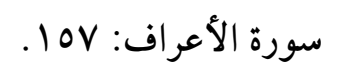

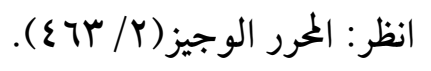

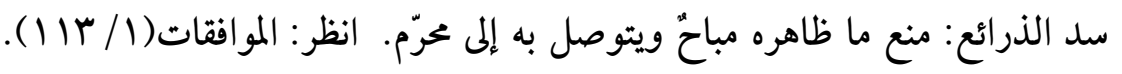

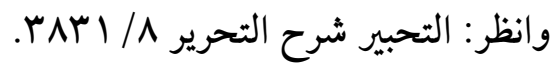

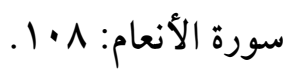

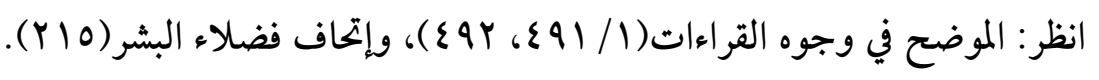


فنهى سبحانه المؤمنين أن يسبوا أوثانهم؛ لأنهم إذا سبوها سبوا الله عز

وجل، ونفر الكفار، وازدادوا كفراً (1).

ثامناً: إن اللّه عز وجل حرم بعض وارد الأشياء على الأمم السابقة عقوبة لهم:

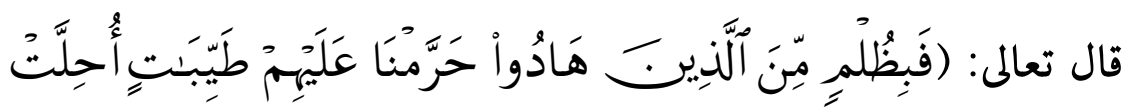

هُمْم) الآية (r) أخبر سبحانه أنه بسبب ظلم اليهود بما ارتكبوه من الذنوب

العظيمة حرم عليهم طيبات كان قد أحلها لهم ("). تاسعاً: الحرام شُرع في القرآن الكريم لحماية مقاصد الشريعة، فهو لدفع

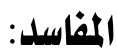

قال الشاطبي - رحمه الله -: (ر تكاليف الشريعة ترجع إلى حفظ مقاصدها في الخلق)( ).

لقد جاءت الشريعة بجفظ الضروريات الخمس، فكل ما يتضمن حفظ هذه الضروريات فهو مصلحة، وكل ما يهدرها فهو مفسدة.

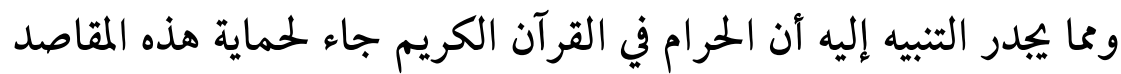

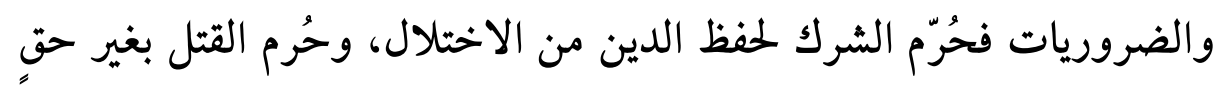

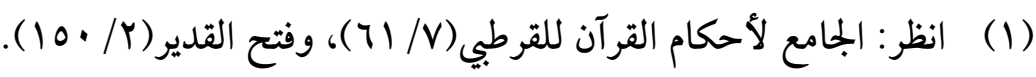

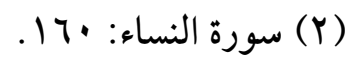

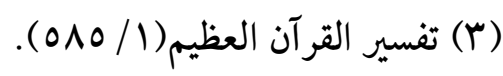

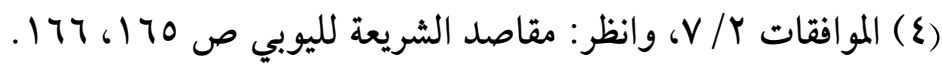




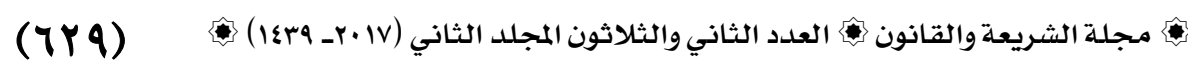

لحفظ النفس، وحُرم الزنا والقذف لحفظ العرض، وحُرم الخمر لحفظ العقل،

وحُرمت السرقة لحفظ المال '(').

فكل ما حرمه الله تعالى في كتابه فهو لا شك لحماية مقاصد الشريعة

وضرورياتها.

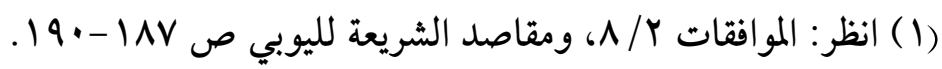


(Tr.)

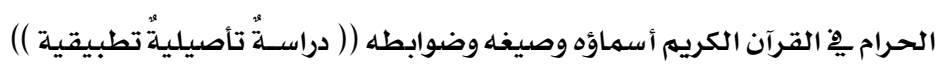

\section{الخاتثة والتوصيات}

فهذه أبرز النتائج والتوصيات اجتهد الباحث في استخلاصها من خلال هذه الدراسة المتواضعة، وهي كالآتي:

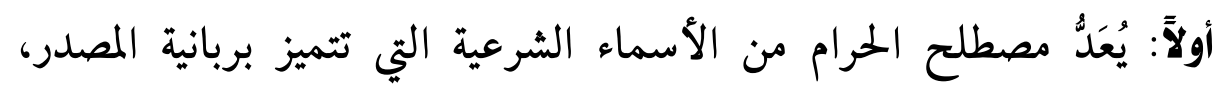

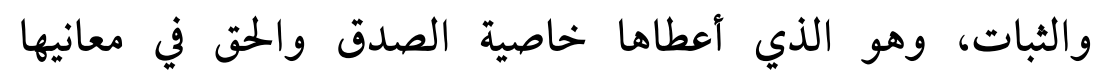

$$
\text { ومدلو لاتها. }
$$

ثانيا: يتصف مصطلح الحرام بالشمولية في تحقيق المقاصد الشرعية.

ثالثاً: الأسماء الشرعية ومنها مصطلح الحرام ليس لأحد أن يبدلها ولا أن

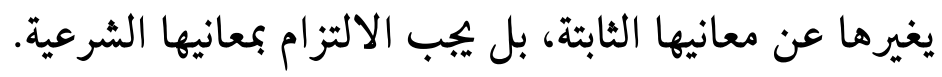

رابعاً: الدقة والوضوح لمصطلح الحرام في القرآن الكريم وذلك لتكرار هذا المصطلح بكثرة في كتاب الله سبحانه.

خامساً: أن مصطلح الحرام له أسماء متعددة في القرآن الكريم. سادساً: أن مصطلح الحرام له صيغ متعددة مسطورة في القرآن الكريم تدل

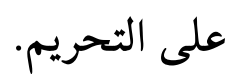

سابعاً: خطورة تسمية المحرمات بغير اسمها، وذلك بقصد التبديل، وتحليل الحرام. 


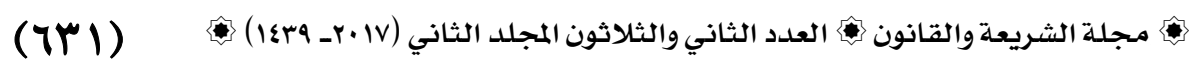

$$
\text { ثامناً: أن مصطلح الحرام يتفاوت في درجاته في القرآن الكريم. }
$$

تاسعاً: أن دائرة الحرام والتحريم ضيقة في القرآن الكريم، حيث إن الأصل

$$
\text { التوسعة والإباحة. }
$$

عاشراً:يوصي الباحث بجمع صيغ الحرام التي لم يعرض لها البحث والتطبيق

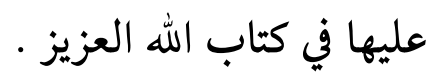

حادي عشر: تحتاج الأسماء الشرعية والمصطلحات القرآنية مزيداً من البحث

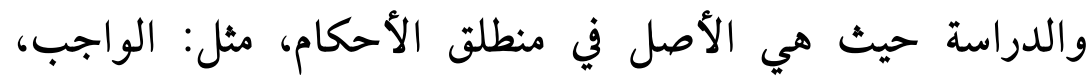

والمباح، وغيرهما.

هذا وأسأل الرب الرحيم أن يتجاوز عن تقصيري، وأن يغفر لي

$$
\text { وللمسلمين }
$$

$$
\text { وآخر دعو انا أن الحمد لله رب العالمين. }
$$




\section{قتائمة المراجع}

1- إتحاف فضلاء البشر في القراءات الأربع عشر، تأليف: أممد بن محمد البناء، عناية: علي بن محمد الضباع، مكتبة ومطبعة المشهد الحسيني، القاهرة.

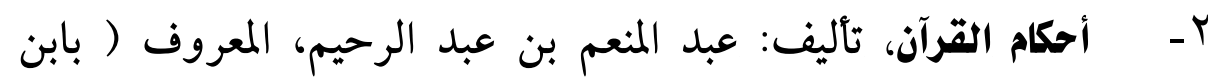

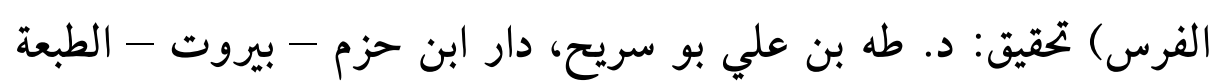

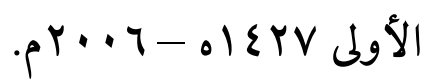
r- أصول الفقه، تأليف: محمد أبو النور زهير، المكتبة الأزهرية للتراث، مصر.

ع- أصول الققه، تأليف: محمد بن مفلح المقدسي، تحقيق وتعليق د. فهد

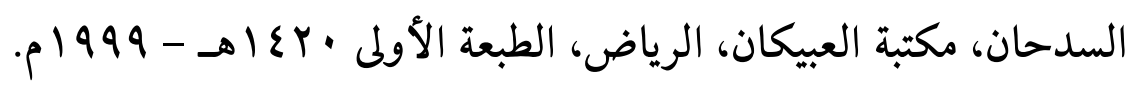

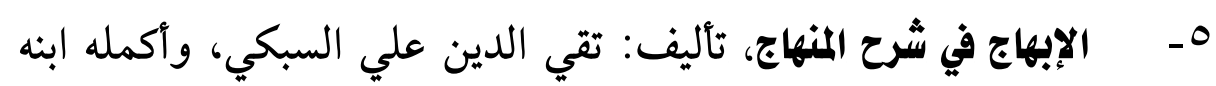
تاج الدين، مطبعة التوفيق مصر.

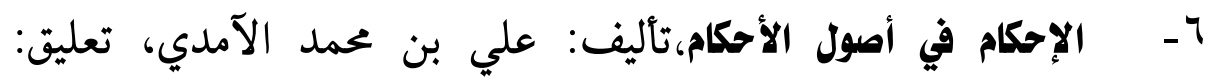

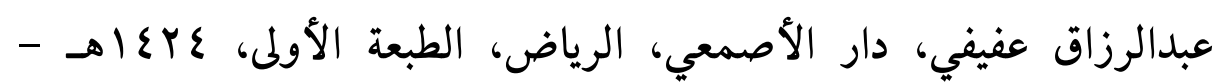

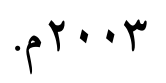
إرشاد الفحول إلى تحقيق الحق من علم الأصول، تأليف: محمد بن علي

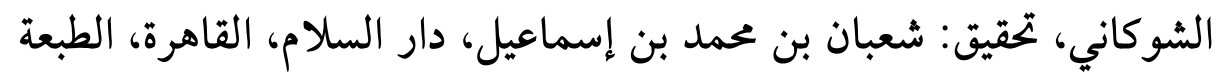

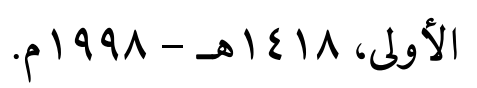




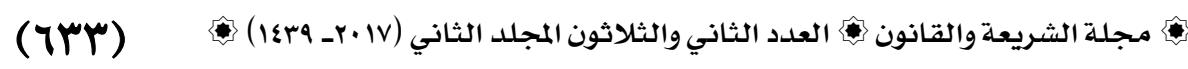

人- الإمام في بيان أدلة الأحكام، تأليف: عز الدين بن عبدالعزيز بن

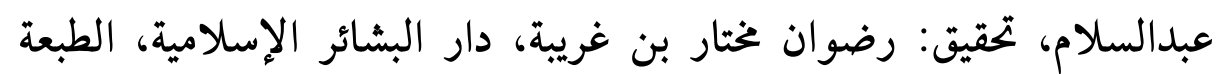

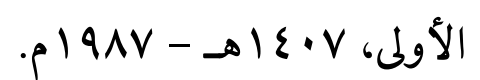

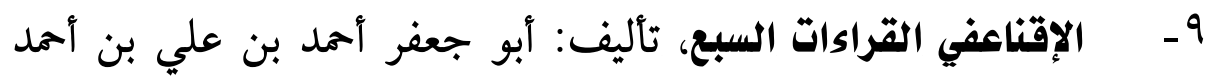

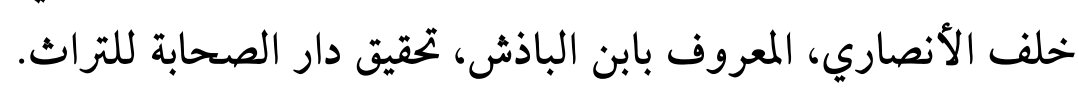

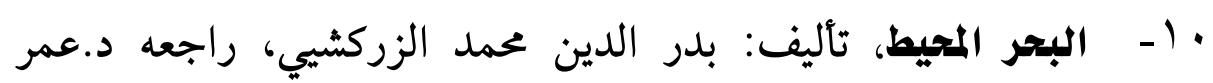

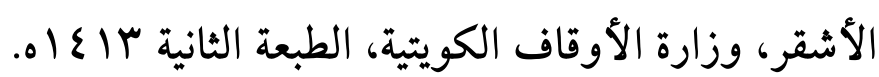

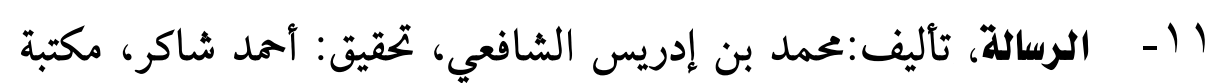

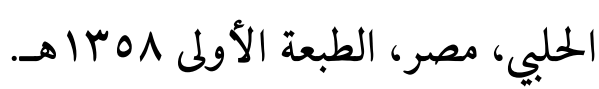

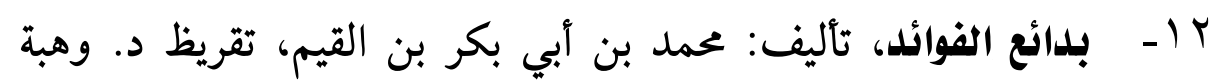

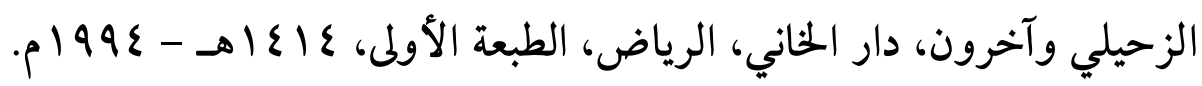

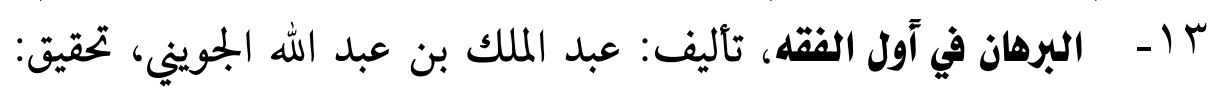

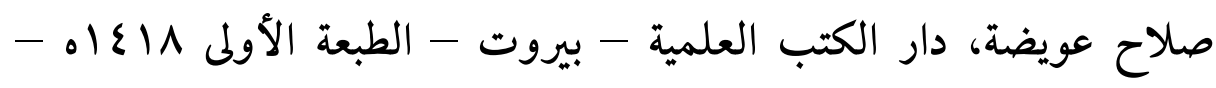
. $199 \mathrm{~V}$ ـ ا - تاج العروس من جوهر القاموس، تأليف: محمد مرتضى الحسني، تحقيق مجموعة من المحققين، دار الهداية.

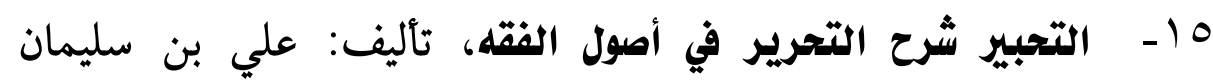

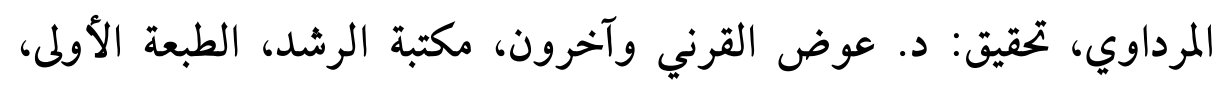

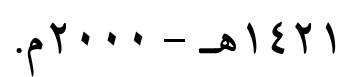
T ا - التحرير والتنوير، تأليف: محمد الطاهر بن عاشور، دار سحنون،

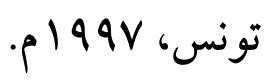




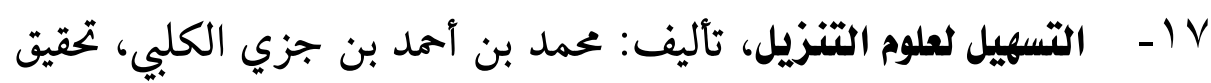

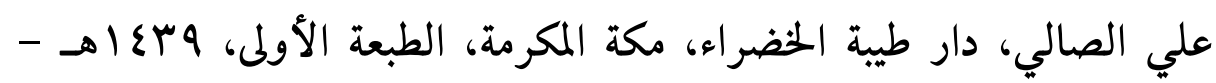
. $r \cdot 11$

1 ا - الفسير البفوي (معالم التنزيل)، تأليف: الحسين بن سعود البغوي،

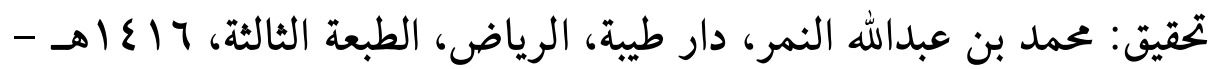
. 1990

9 أ- تفسير البيضاوي، تأليف: عبدالله بن عمر البيضاوي، دار الفكر،

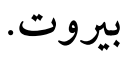

• ץ- تفسير القرآن العظيه، تأليف: إسماعيل بن عمر بن كثير، دار الفكر،

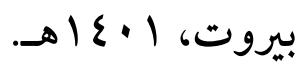
ا ب- - تفسير المنار، تأليف: محمد رشيد رضا، الميئة المصرية العامة للكتاب،

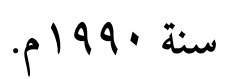
Y Y - تفسير النسفي(مدارك التنزيل وحقائق التأويل)،تأليف: عبدالله بن أحمد

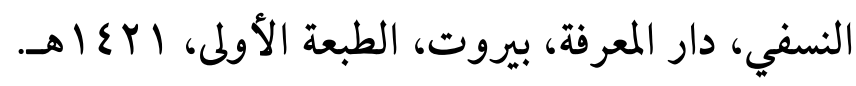

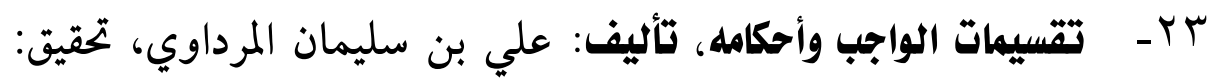

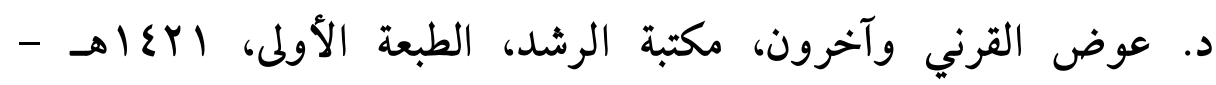

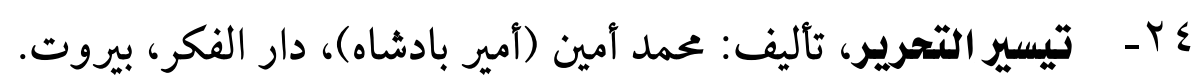

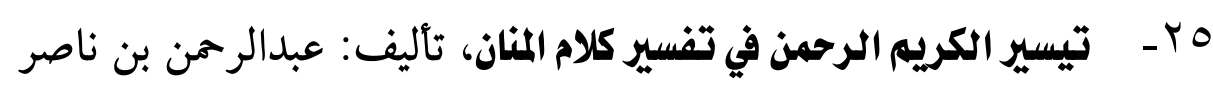

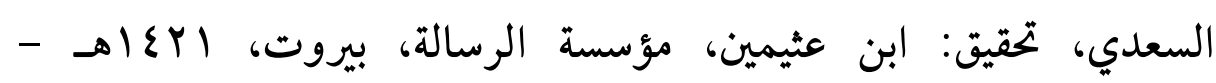




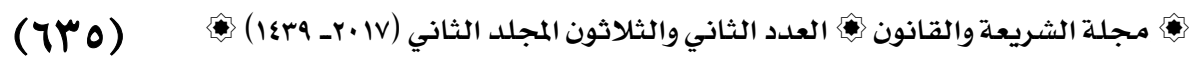

جr - جامع البيان عن تأويل آي القرآن، تأليف: محمد بن جرير الطبري، دار

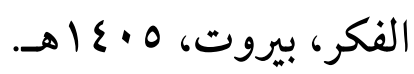
الجامع - TV

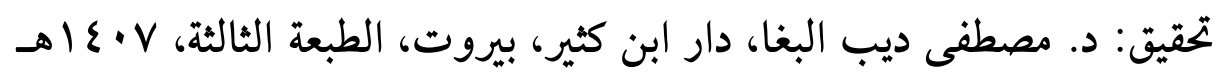
م) $91 \mathrm{~N}-$ الجر - الجامع لأحكام القرآن، تأليف: محمد بن أمد القرطبي، دار الشعب،

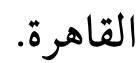

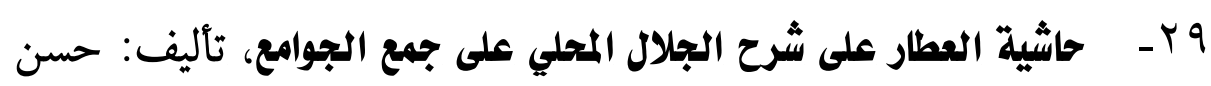
بن محمد العطار، دار الكتب العلمية، بيروت.

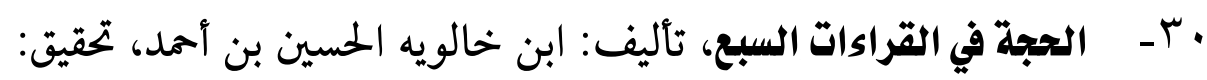

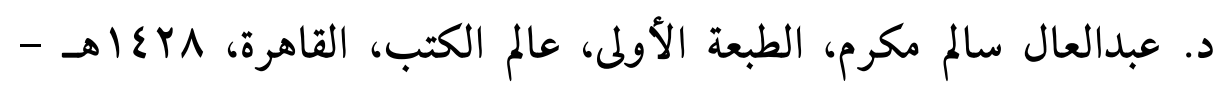
p r. v v آ⿱ - حجة القراءات، تأليف: عبدالرحمن بن محمد بن زنجلة، تحقيق: سعيد

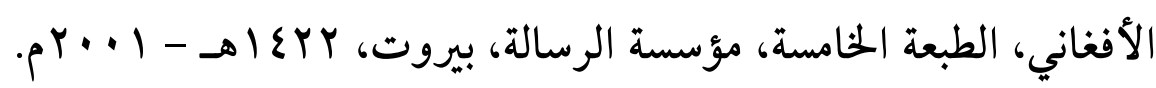

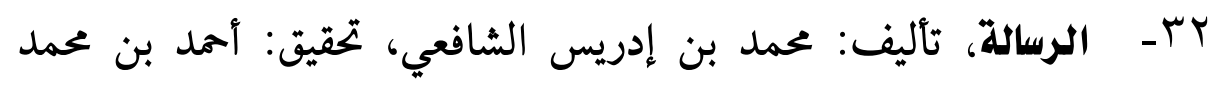

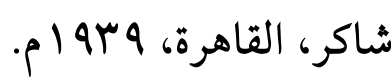
بr- الحرام في التشريع الإسلامي، تأليف الدكتور: صبغة الله غلام بيي،

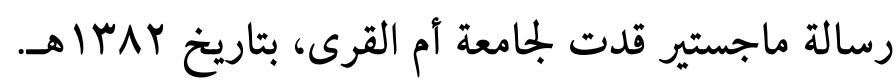

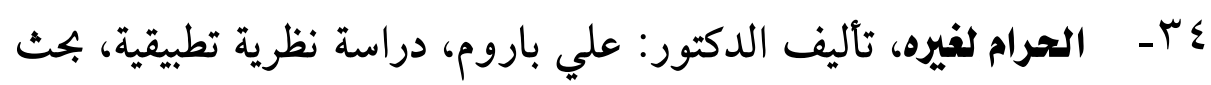

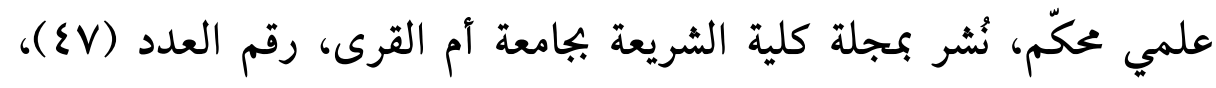

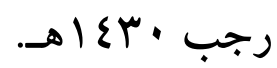


هـ- روح المعاني في تفسير القرآن العظيم والسبع المثاني، تأليف: محمود

$$
\text { الألوسي، دار إحياء التراث العربي، بيروت. }
$$

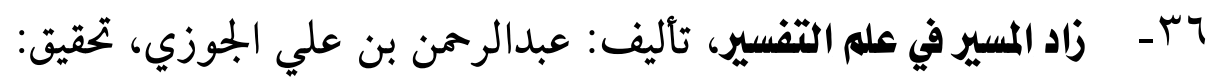

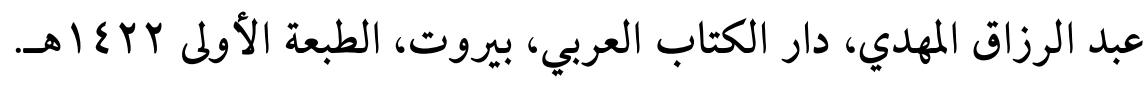

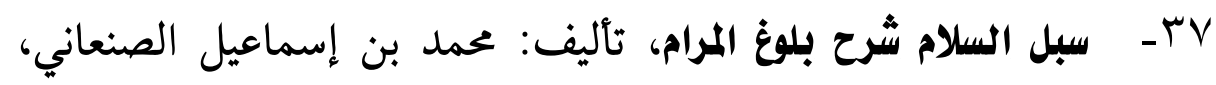

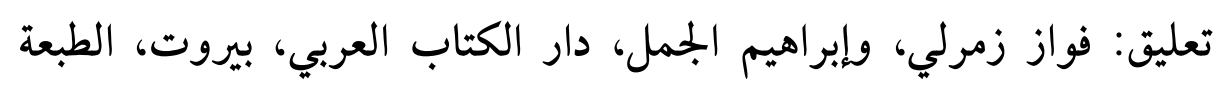

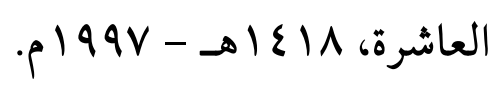

^r- السلسلة الصحيحة، تأليف: محمد ناصر الدين الألباني، مكتبة المعارف،

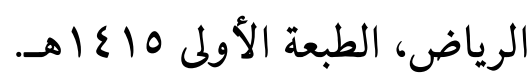

qr- سنز الترمذي، تأليف: محمد ين عيسى الترمذي، تحقيق: أحمد شاكر،

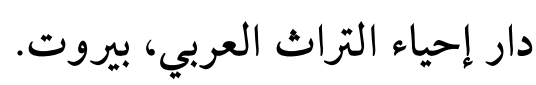

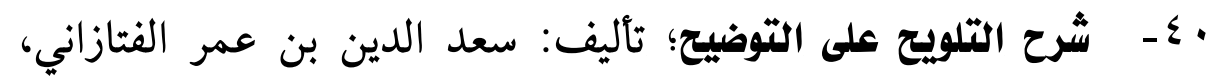

$$
\text { مكتبة صبيح، مصر. }
$$

اءـ- شرح طيبة النشر في القراءات العشر، للنويري محمد بن علي ـ تحقيق

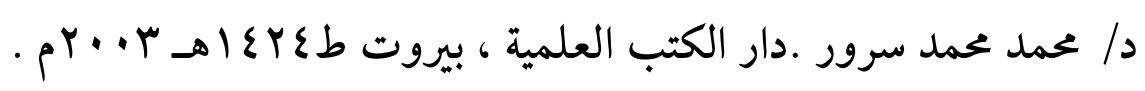

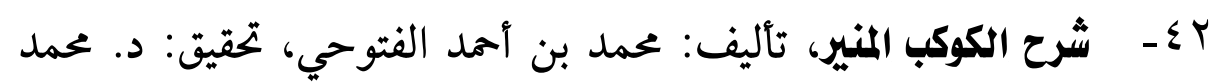

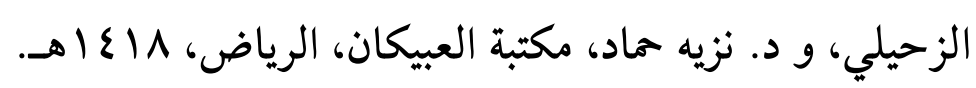

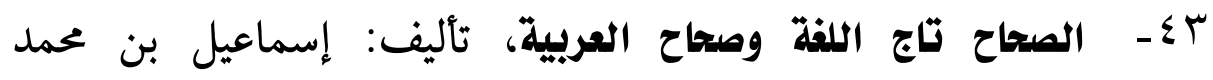

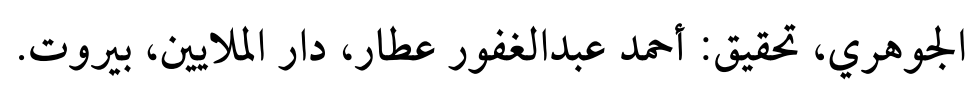


؟ ـ - صيخ التحريم عند الأصوليين مع التطبيق على ما ورد منها في سورة المائدة،

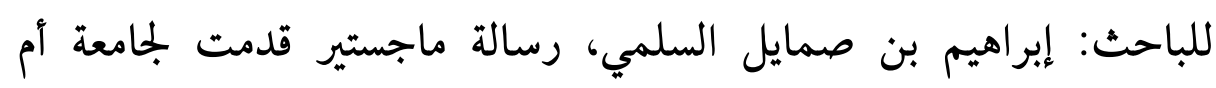

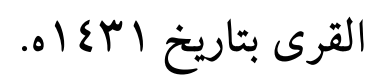

0ــ- طلائع البشر في توجيه القراءات العشر، تأليف: محمد الصادق

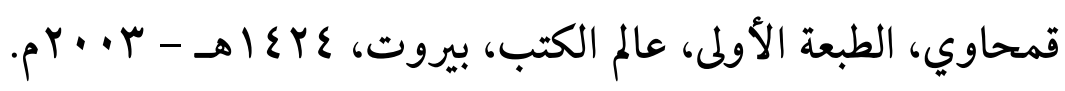

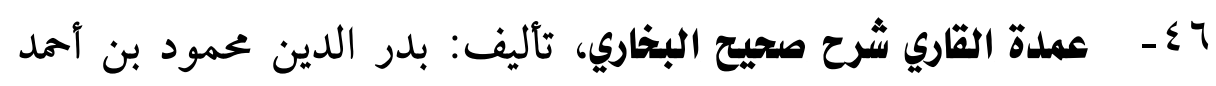
العيني، دار إحياء التراث العربي، بيروت. \&V المخزومي، و د. إبراهيم السامرائي، دار ومكتبة الهلال.

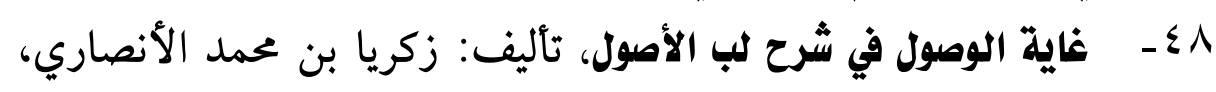
دار الكتب العربية الكبرى، مصر.

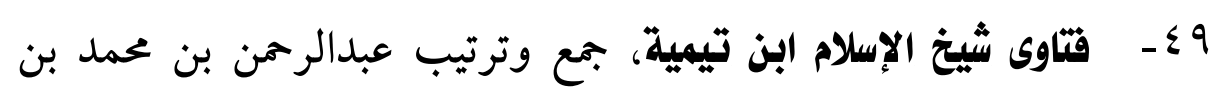

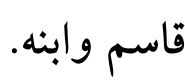

• 0ـ قتح القدير الجامع بين فني الرواية والدراية في علم التفسير، تأليف: محمد بن علي الشوكاني، دار الفكر، بيروت.

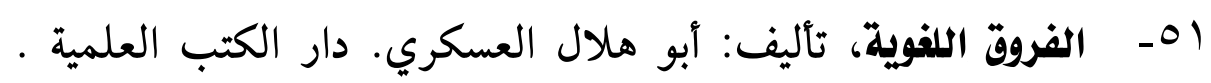

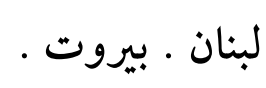
ror الفصول في الأصول، تأليف: أحمد بن علي الجصاص، تحقيق: د. عجيل

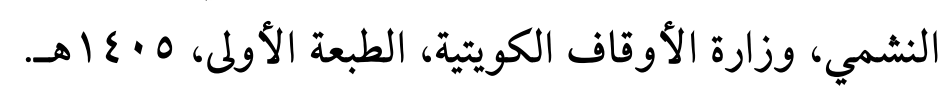


(7rA)

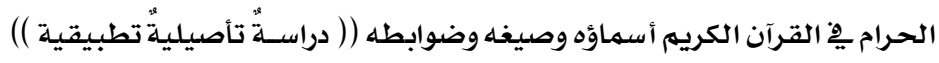

ror القاموس المحيط، تأليف: محمد بن يعقوب الفيروزآبادي، تحقيق:

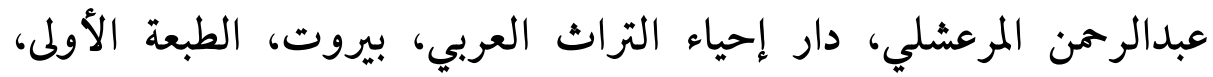

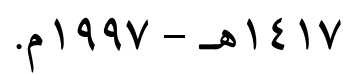
عـ - القراءات الشاذة، تأليف: ابن خالويه الحسين بن أحمد، تحقيق: محمد

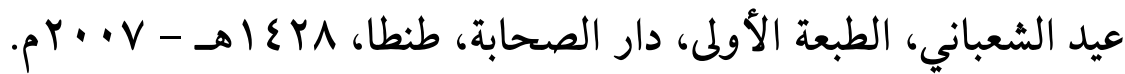

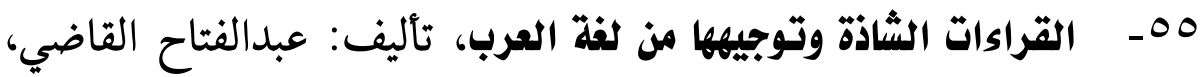

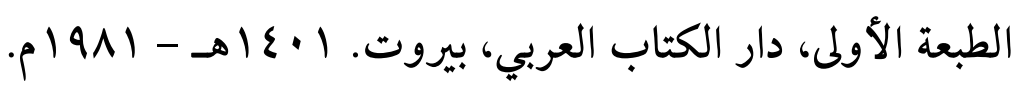

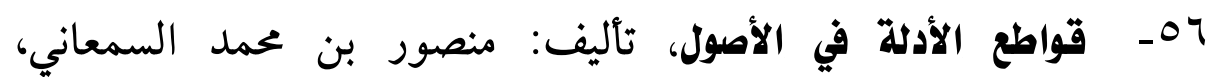

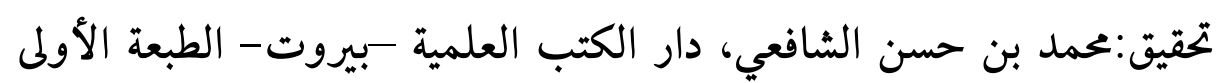
- إ)

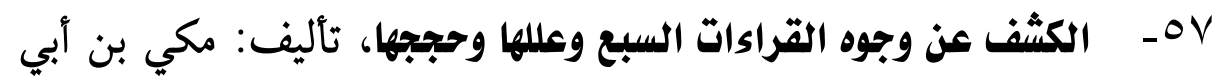
طالب القيسي، تحقيق: د. محي الدين رمضان، مجمع اللغة العربية بدمشق،

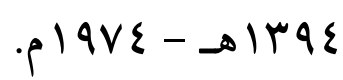

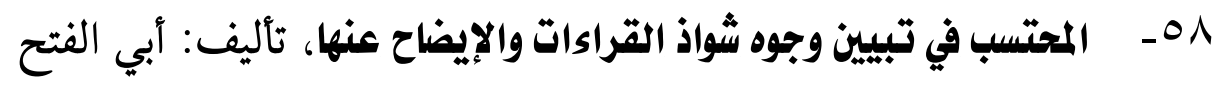
عثمان بن جني، تحقيق: علي النجدي ناصف، و د. عبدالحليم النجار، و د.

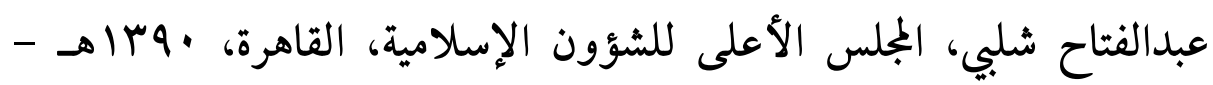
.01979 هـــ المحرر الوجيز في تفسير الكتاب العزيز، تأليف: عبدالحق بن غالب بن عطية الأندلسي، تحقيق: عبدالسلام عبدالشافي، دار الكتب العلمية، لبنان،

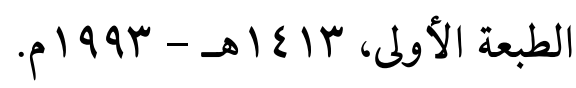


• 7- المدخل إلى مذهب الإمام أحمد بن حنبل، تأليف: عبد القادر بن بدران،

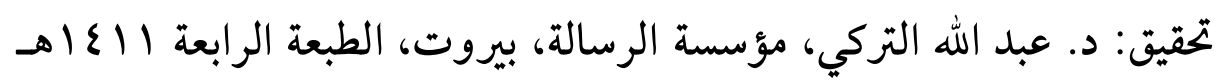
م 1991آT- المحصول في علم الأصول، تأليف: محمد بن عمر الرازي، تحقيق: طه

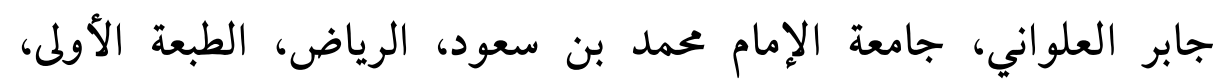
- (1). rT- المستصفى من علم أصول الفقه، تأليف: محمد بن محمد الغزالي، تحقيق

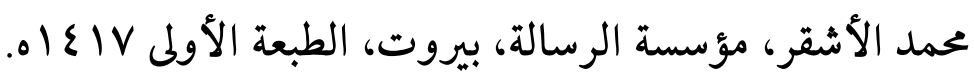

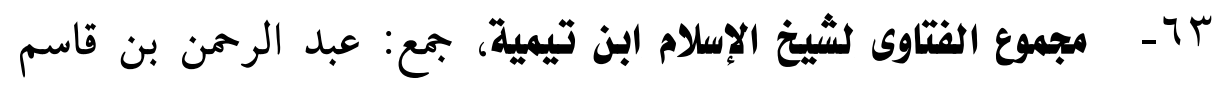
وابنه، الرئاسة العامة لشؤون الحرمين الشريفين.

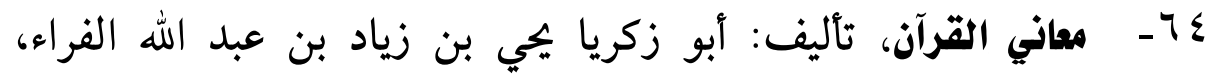

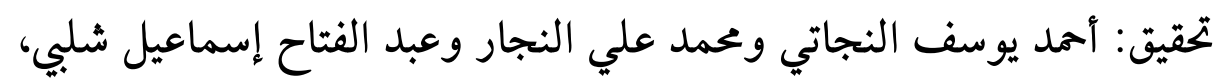

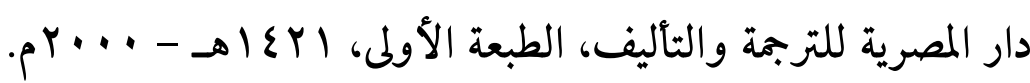

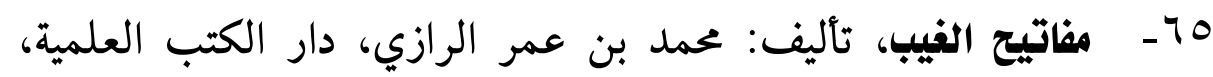

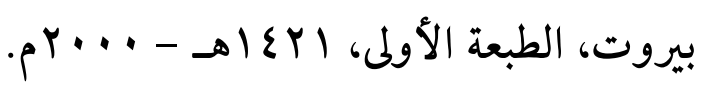

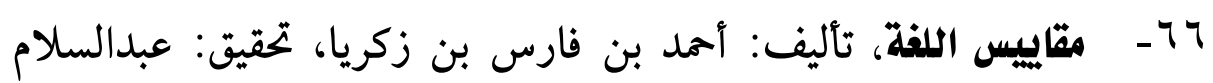

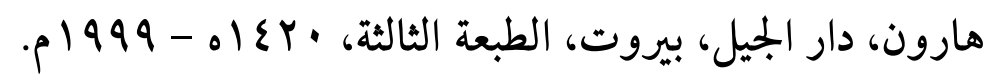

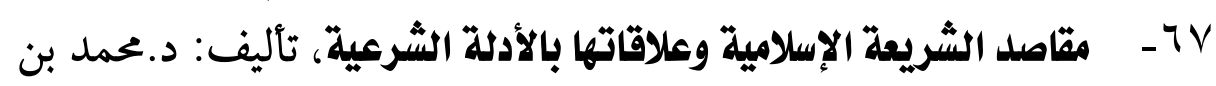

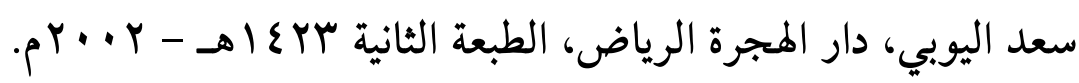

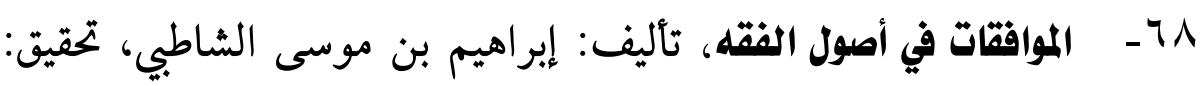
عبدالله دراز، دار المعرفة، بيروت. 
$(7 \varepsilon \cdot)$ الحرام يو القرآن الكريم أسماؤه وصيغه وضوابطه ( (دراسـة تأصيليةّ تطبيقية ))

97 - الموضح في وجوه القراءات وعللها، تأليف: أبي مريم الشيرازي، تحقيق:

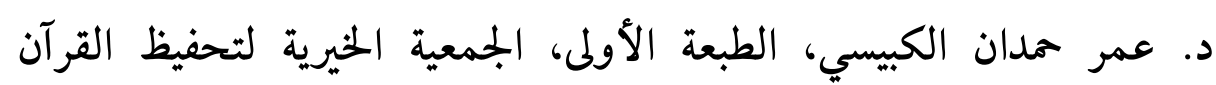

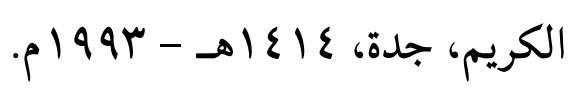

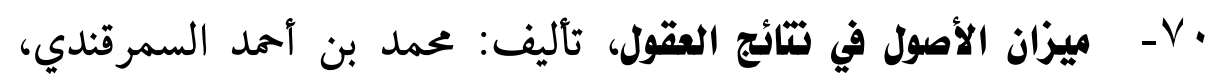

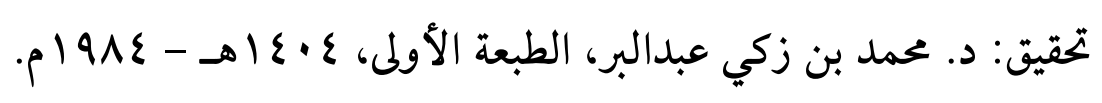

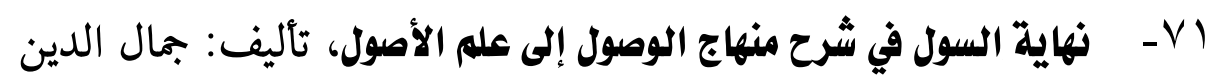

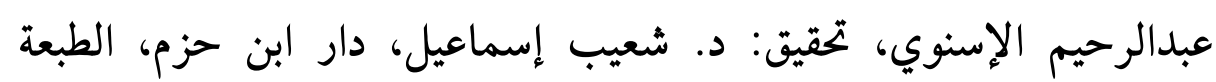

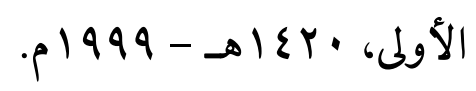

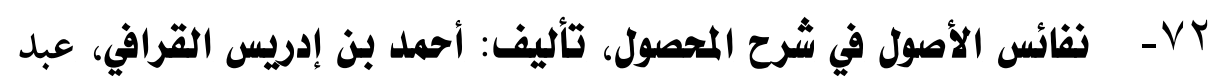

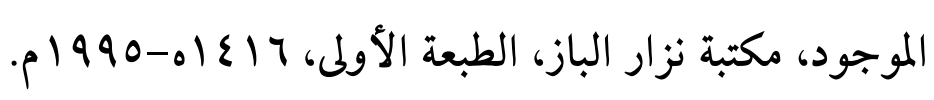

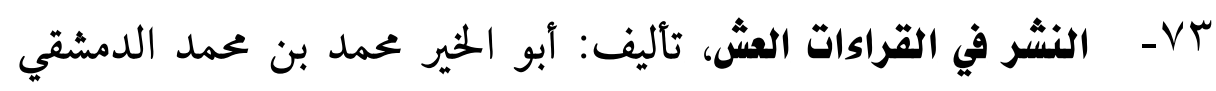

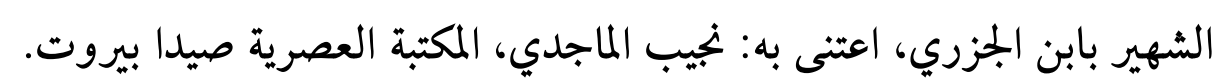




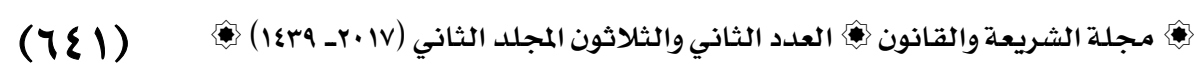

فهرس الموضوعات

\begin{tabular}{|c|c|}
\hline الصفحة & الموضـــــع \\
\hline oVV & المقدمة. \\
\hline ০^r & المبحث الأول:تعريف الحرام، والفرق بين الحرام، والتحريم، \\
\hline 09. & المبحث الثاني:أسماء الحرام في القرآن الكريم. \\
\hline $09 V$ & المبحث الثالث: صيخ الحرام من خلال القرآن الكريم \\
\hline 719 & المبحث الرابع:ضو ابط وقو اعد الحرام في القرآن الكريم. \\
\hline Tr. & الخاتمة والنتائج. \\
\hline r & قائمة المراجع. \\
\hline $7\{1$ & الفهرس. \\
\hline
\end{tabular}

